JULIANA GUIMARÃES ZULIAN

\title{
DIFERENCIAÇÃO CELULAR NO EPITÉLIO GÁSTRICO DE RATOS SUBMETIDOS AO DESMAME PRECOCE: AVALIAÇÃO DA AÇÃO DA CORTICOSTERONA
}

Tese apresentada ao Programa de PósGraduação em Biologia Celular e Tecidual do Instituto de Ciências Biomédicas da Universidade de São Paulo, para obtenção do Título de Doutor em Ciências. 
JULIANA GUIMARÃES ZULIAN

\section{DIFERENCIAÇÃO CELULAR NO EPITÉLIO GÁSTRICO DE RATOS SUBMETIDOS AO DESMAME PRECOCE: AVALIAÇÃO DA AÇÃO DA CORTICOSTERONA}

Tese apresentada ao Departamento de Biologia Celular e do Desenvolvimento do Instituto de Ciências Biomédicas da Universidade de São Paulo, para obtenção do Título de Doutor em Ciências.

Área de concentração: Biologia Celular e Tecidual.

Orientadora: Prof ${ }^{\mathrm{a}}$. Dr ${ }^{\mathrm{a}}$. Patrícia Gama.

Versão original. 
DADOS DE CATALOGAÇÃO NA PUBLICAÇÃO (CIP)

Serviço de Biblioteca e Informação Biomédica do

Instituto de Ciências Biomédicas da Universidade de São Paulo

(C) reprodução parcial

Zulian, Juliana Guimarães.

Diferenciação celular no epitélio gástrico de ratos submetidos ao desmame precoce: avaliação da ação da corticosterona / Juliana Guimarães Zulian. -- São Paulo, 2016.

Orientador: Patrícia Gama.

Tese (Doutorado) - Universidade de São Paulo. Instituto de Ciências Biomédicas. Departamento de Biologia Celular e do Desenvolvimento. Área de concentração: Biologia Celular e Tecidual. Linha de pesquisa: Diferenciação celular do epitélio gástrico.

Versão do título para o inglês: Cell differentation in gastric epithelium of early weaned rats: corticosterone action evaluation

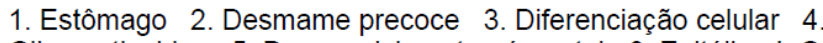
Glicocorticoides 5. Desenvolvimento pós-natal 6. Epitélio I. Gama, Patrícia II. Universidade de São Paulo. Instituto de Ciências

Biomédicas. Programa de Pós-Graduação em Biologia Celular e Tecidual III. Título. 


\begin{abstract}
Candidato(a): $\quad$ Juliana Guimarães Zulian.
Título da Tese: Diferenciação celular no epitélio gástrico de ratos submetidos ao desmame precoce: avaliação da ação da corticosterona.
\end{abstract}

Orientador(a): $\quad$ Patrícia Gama.

A Comissão Julgadora dos trabalhos de Defesa da Tese de Doutorado, em sessão pública realizada a .................., considerou
( ) Aprovado(a)
( ) Reprovado(a)

\begin{abstract}
Examinador(a): Assinatura:
Nome:

Instituição:

Examinador(a): Assinatura:

Nome:

Instituição:

Examinador(a): Assinatura:

Nome:

Instituição:

Examinador(a): Assinatura:

Nome:

Instituição:

Presidente: Assinatura:

Nome:

Instituição:
\end{abstract}




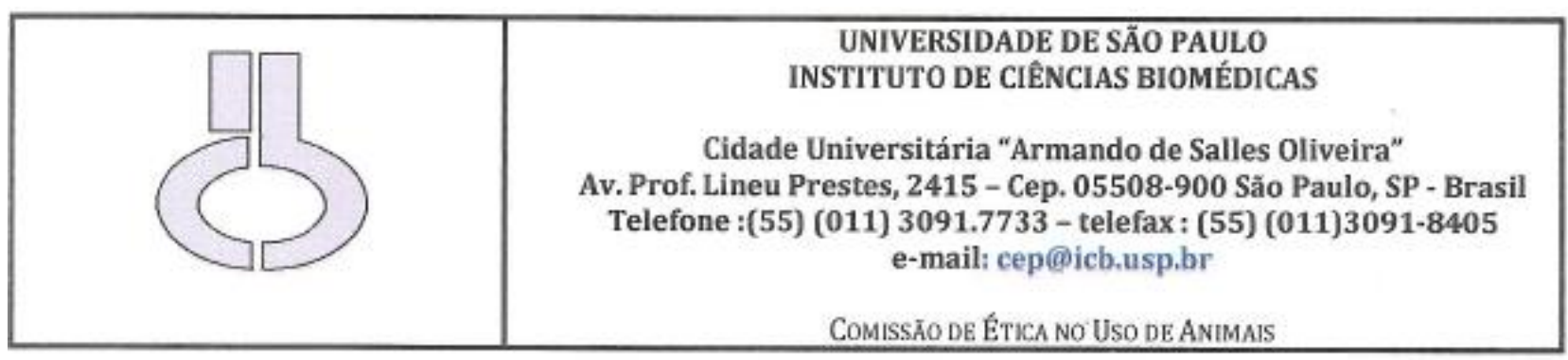

Decl. CEEA.011/2010

\section{E C L A R A Ç Ã O}

Em adendo ao Certificado 086/08/CEEA, datado de $18.09 .08 \mathrm{e}$ por solicitação da Profa. Dra. Patrícia Gama, responsável pela linha de Pesquisa, autorizo a inclusão das alunas Heloísa Ghizoni, Juliana Zulian ao Projeto de Pesquisa "Mecanismo de regulação do crescimento gástrico: interação entre padrão alimentar, corticosterona e fatores de crescimento", uma vez que se trata de utilização da mesma espécie animal e de métodos experimentais similares ao referido certificado.

São Paulo, 15 de março de 2010.

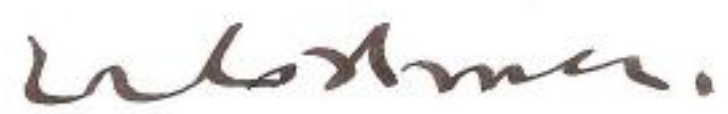

Prof. Dr. Wothan Tavares de Lima

Coordenador da CEEA

ICB/USP 


\section{Certificado}

Certificamos que o protocolo registrado sob $n^{\circ} \mathbf{0 1 8}$ nas fls.029 do livro 03 para uso de animais em experimentação, sob a responsabilidade do Prof(a) Dr(a) Patrícia Gama, Coordenador (a) da Linha de pesquisa "Expressão gênica, diferenciação celular e funções gástricas: distúrbios alimentares durante o desenvolvimento pós-natal podem alterar o programa de crescimento em ratos?" do qual participam o(s) aluno(s) Juliana Guimarães Zulian, Pós-Doutorando Daniela Ogias, Iniciação Científica Larissa Yukari M. Hosoya, Isadora Rattes, Estagiário Gizela Maria Agostini Zonta, está de acordo com os Princípios Éticos de Experimentação Animal adotado pela Sociedade Brasileira de Ciência de Animais de Laboratório (SBCAL) e foi aprovado pela COMISSÃO DE ÉTICA NO USO DE ANIMAIS (CEUA) em 10.02.2015, com validade de 4 anos.

São Paulo, 23 de fevereiro de 2015.

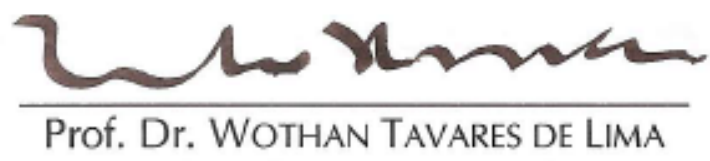

Coordenador- CEUA- ICB/USP

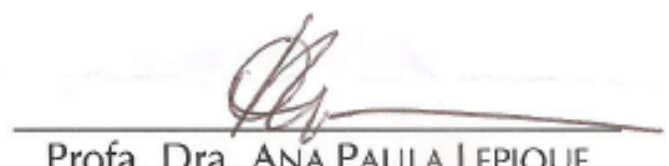

Profa. Dra. ANA PAULA LePIQUE Secretária- CEUA - ICB/USP 


\section{AGRADECIMENTOS ESPECIAIS}

À Prof ${ }^{\mathrm{a}}$. Dr ${ }^{\mathrm{a}}$. Patrícia Gama, minha orientadora. Por toda a ajuda e paciência dedicadas a mim nestes últimos meses! Não só nos últimos meses, mas nos últimos seis anos. Por ter acreditado na minha capacidade e confiado na execução deste trabalho. Por todos os conselhos, por todas as risadas, por todos os momentos. Por ensinar e compartilhar seus conhecimentos sempre. Por estar sempre presente. Muito obrigada! 
Aos meus pais! Que sem o apoio deles nada disso seria possível. Muito obrigada por dedicarem suas vidas a minha. Por sempre colocarem a nossa formação estudantil (minha e de meus irmãos) acima de tudo. E por me ensinarem desde sempre a dar o melhor de mim em tudo que eu quisesse realizar. Por me darem todo o suporte necessário para mudar de cidade e conquistar o sonho da pós-graduação e por, durante esses anos, entenderem a minha ausência. Muito obrigada por serem meus pais! 


\section{AGRADECIMENTOS}

A Deus! Por possibilitar que eu chegasse até aqui, com dedicação e persistência.

A todos os meus familiares, por me incentivarem e compreenderem minhas ausências.

Aos colegas de trabalho e amigos do laboratório de Biologia dos Epitélios Digestivos: Cruz Alberto M Rigonati (Júnior), por sempre atender a todos os meus pedidos (às vezes confusos!) de cortes de lâminas para os inúmeros testes de protocolo; Gizela, pelo carinho, por me ajudar sempre que necessário e por dividir seus conhecimentos; Kethleen pelo carinho, por sua alegria contagiante e por todos os conselhos; e Melissa pela gentileza e dedicação com as quais sempre executou todos os trabalhos solicitados.

Ao Dr. Renato Astorino Filho por me apresentar à USP e, através do seu exemplo, mostrar que uma pós-graduação com qualidade superior é possível!

Ao Dr. Alexandre Lobo por me apresentar ao excelente grupo de pesquisa da $\operatorname{Prof}^{\mathrm{a}}$. Dr ${ }^{\mathrm{a}}$. Patrícia Gama, possibilitando que eu me encantasse com a histologia.

À Prof ${ }^{a}$. Dra . Maria Inês Borella, que com muita dedicação me aproximou um pouco mais da atividade de um professor, durante minha primeira experiência como monitora. E por estar sempre por perto com um sorriso gentil!

Aos Prof ${ }^{\mathrm{es}}$. Dr ${ }^{\mathrm{a}}$. Claudima Ferini Pacicco Lofti, Dr ${ }^{\mathrm{a}}$. Gláucia Maria Machado-Santelli, Dr. Ruy Gastaldoni Jaeger e à Drª . Cilene Rebouças de Lima pelas valiosas contribuições e sugestões feitas a esse trabalho durante os exames de qualificação.

Às Profas. Dr ${ }^{\text {a }}$ Estela M. A. F. Bevilacqua, Dr ${ }^{a}$. Gláucia Maria Machado-Santelli, Dra ${ }^{\text {. }}$ Vanessa Morais Freitas, Dr ${ }^{\mathrm{a}}$. Nathalie Cella e Dra. Telma Maria Tenório Zorn por, de maneira sempre gentil, permitirem o livre acesso aos seus laboratórios e disponibilizarem seus equipamentos para a adequada realização dos meus experimentos. 
À Luciana Osaki, pelas palavras de conforto e incentivo nas longas conversas. Pela amizade, ensinamentos e companheirismo disponibilizados a mim sempre de forma alegre e incondicional!

À Daniela Ogias, por estar ao meu lado. Para me ensinar, me fazer rir e me ajudar nos diversos momentos desafiadores desta caminhada!

À Heloisa Ghizoni, por alegrar nossos dias e por estar sempre disposta a ajudar.

À Natália Bittar, por ser uma amiga que me inspira, com sua personalidade e dedicação, a ser cada dia melhor!

À Priscila Figueiredo por estar sempre disposta, de maneira alegre e gentil, a me ajudar. Pelo precioso tempo dedicado a me ensinar.

À Ana Paula Fiore, pelos ensinamentos, pelas conversas e pela ajuda nos diversos experimentos.

À Larissa Hosoya, minha pupila! Pela dedicação aos experimentos necessários para construção desta tese. Por ser minha amiga e estar sempre disposta a me escutar!

À Camila, Ludimila e Isadora por estarem sempre dispostas a me ajudar e por dedicarem seus tempos livres ao laboratório em meio a agitada rotina da graduação.

À Fernanda, Adriane, Rose e Marlene, técnicas do departamento, que mesmo não trabalhando diretamente comigo, sempre estiveram dispostas a me ajudar, ensinar e atender a todos os meus pedidos por reagentes e suporte técnico.

A todos os meus colegas da pós-graduação, com quem tive a oportunidade de conviver, dividir anseios e compartilhar conhecimentos. Em especial, à Camila, Joana, Kelly, Luana, Vívian e Mariana, que passaram por disciplinas comigo e me ajudaram a compreender os artigos mais difíceis da minha vida!... 
Às minhas queridas amigas da graduação, que mesmo à distância me apoiaram, incentivaram, compreenderam minhas ausências e garantiram todos os momentos de descontração necessários para amenizar as preocupações com a pós-graduação.

Aos funcionários do biotério, Braz, Cláudio e Fernando, que prestaram todos os cuidados necessários para a manutenção dos nossos animais em condições ideais de experimentação. Obrigada por toda a ajuda!

Às funcionárias e secretárias do departamento, Ana Lúcia, Celiana, Eloise e Regina, que me atenderam prontamente sempre que precisei.

À equipe da biblioteca do Instituto de Ciências Biomédicas, que sempre me atendeu com simpatia, cordialidade e presteza.

Ao Conselho Nacional de Desenvolvimento Científico e Tecnológico (CNPq), à Coordenação de Aperfeiçoamento de Pessoal de Nível Superior (Capes) e à Fundação de Amparo à Pesquisa do Estado de São Paulo (FAPESP) pelo suporte financeiro, essencial para a obtenção dos nossos resultados. 


\section{RESUMO}

ZULIAN, J . G . Diferenciação celular no epitélio gástrico de ratos submetidos ao desmame precoce: avaliação da ação da corticosterona. 2016. 84f . Tese (Doutorado em Biologia Celular e Tecidual) - Instituto de Ciências Biomédicas, Universidade de São Paulo, São Paulo, 2016.

O epitélio do corpo gástrico é formado por longas glândulas tubulares que se abrem em fossetas recobertas por células mucosas superficiais. Ao longo da glândula encontramos principalmente células parietais, células mucosas do colo (CMC) e células zimogênicas $(\mathrm{CZ})$. A mucosa gástrica do rato atinge seu estágio final de maturação durante a terceira semana de vida pós-natal, coincidindo com a etapa de transição alimentar. A partir do $14^{\circ}$ dia de vida, os filhotes começam a ingerir a ração juntamente com o leite materno e no $21^{\circ}$ dia é feito o desmame em biotério. O desmame precoce (DP) consiste na abrupta interrupção da amamentação aos 15 dias de vida. Esta modificação da dieta está relacionada à aceleração da maturação de diversos órgãos, ao aumento da diferenciação das CMC e a elevação dos níveis de corticosterona (principal glicocorticoide (GC) encontrado em roedores). A atividade dos GCs pode ser inibida pelo uso do RU486, antagonista do receptor de glicocorticóides. O objetivo do nosso estudo foi investigar a ação da corticosterona sobre o padrão de maturação do epitélio gástrico de ratos submetidos ao desmame precoce, e avaliar se os efeitos são mantidos até o início da vida adulta. Para isso, utilizamos quatro grupos experimentais: amamentado (A), amamentado tratado com RU486 (ARU), desmame precoce (DP) e desmame precoce tratado com RU486 (DPRU). Através das análises de RT-qPCR, em ratos de 17 dias, constatamos que o DP elevou a expressão dos genes Muc5ac, Bhlha15, Pgc e diminuiu a expressão de Msn (comparando ARU e DPRU) e de Pga5, enquanto que o RU486 reverteu os resultados obtidos para os genes $P g c$ e $M u c 5 a c$, reduziu a expressão de Gif no DPRU, reduziu a expressão de Futl no ARU e aumentou a expressão de Muc6 (genes marcadores de maturação da glândula gástrica). A eficácia do tratamento com RU486 foi atestada pela redução no RNAm para a SGK1, que foi elevado pelo DP. A população de CMC foi avaliada utilizando-se as histoquímicas de PASAB e lectina GSII, e a imuno-histoquímica para mucina 6. Em animais de 17 e 18 dias, observamos que o DP aumentou o número de CMC, enquanto que o RU486 reverteu este resultado. As CZ foram analisadas através das imuno-histoquímicas para Mist1 e pepsinogênio C (PGC). Em filhotes, vimos que o DP elevou a população de células Mist1- positivas e PGC-positivas, entretanto a inibição da corticosterona reverteu o resultado apenas para o PGC. Em ratos de 30 dias, obtivemos os seguintes resultados: redução da expressão de Futl causada tanto pelo DP quanto pelo RU486; redução no RNAm para moesina no grupo ARU e DP, e elevação no grupo DPRU; redução da expressão de Pga5, provocada pelo RU486; manutenção dos efeitos do DP sobre o gene $P g c$; manutenção dos resultados, tanto do DP quanto de RU486, sobre a população de CMC positivas para PASAB e mucina 6 e dos efeitos do RU486 sobre as células imunomarcadas para PGC. Concluímos então, que a corticosterona elevada pelo DP desempenha um papel fundamental na completa diferenciação das CMC e CZ.

Palavras-chave: Estômago. Desmame precoce. Diferenciação celular. Glicocorticoides. Desenvolvimento pós-natal. 


\begin{abstract}
ZULIAN, J . G . Cell differentiation in the gastric epithelium of early weaned rats: corticosterone action evaluation. 2016. 84 p. Ph.D Thesis (Cell and Tissue Biology) Instituto de Ciências Biomédicas, Universidade de São Paulo, São Paulo, 2016.
\end{abstract}

The epithelium of the stomach corpus is lined by long tubular glands. The foveolas are covered by surface mucous cells and in the glands we have parietal cells, mucous neck cell and zymogenic cells. The rat's gastric mucosa completes the maturation process during the third post-natal week, throughout the food transition process. At $14^{\text {th }}$ day, the pups begin to eat chow with maternal milk and at $21^{\text {st }}$ day the weaning, for experimental animals, is complete. The early weaning consists in the abrupt suckling interruption at $15^{\text {th }}$ day. This diet modification is related to accelerated maturation process of diverse organs, increase in mucous neck cells differentiation and in corticosterone levels (the main glucocorticoid hormone in rats). The glucocorticoids (GCs) action can be inhibited by RU486, a glucocorticoid receptor antagonist. The aim of this study was to evaluate if the increase in corticosterone levels triggered to early weaning could affect gastric epithelium maturation and to verify if these changes could persist to adult age. For that, we had four experimental groups: suckling, suckling-RU486, early weaning and early weaning-RU486. Using RTqPCR, in 17-d-old rats, we observed that early weaning increased Muc5ac, Bhlhal5 and Pgc and decreased Msn (comparing suckling-RU486 and early weaning-RU486) and Pga5 expression, while RU486 reverted the results for $P g c$ and Muc5ac, reduced Gif expression in early weaning-RU486, reduced Fut1 expresion in suckling-RU486 and increased Muc6 expression (genes related to gastric maturation process). The efficiency of RU486 treatment was attested by the reduction of SGK1 mRNA levels, which were elevated by early weaning. Mucous neck cells population was evaluated using the histochemistry reactions of PASAB and GSII lectin, and the immune-hystochemistry for mucin 6. In 17 and 18-d-old animals, we noted that early weaning increased mucous neck cells number as RU486 reverted this result. The zymogenic cells were analysed with immune-histochemistry reactions for Mist 1 and for pepsinogen $\mathrm{C}$ (PGC). In pups, we found that early weaning increased Mist1-positive and PGC-positive cells populations, although corticosterone inhibition reverted only the result for PGC. In 30-d-old rats, we had the following results: reduction on Futl expression caused by early weaning; reduction on mRNA levels for moesin in SRU and early weaning groups, and elevation on early weaning-RU486; reduction on Pga5 expression provoked by RU486; the results over $P g c$ were maintained; the results, caused both by early weaning as RU486, over the population of mucous neck cells positives for PASAB and positives for mucin 6 were maintained, as well as the effects of RU486 over PGC immune-stained cells. We concluded that the increase in corticosterone levels, caused by early weaning, has a fundamental role in the mucous neck cells and zymogenic cells complete differentiation.

Keywords: Stomach. Early weaning. Cell differentiation. Glicocorticoids. Postnatal development. 


\section{LISTA DE ILUSTRAÇÕES}

Figura 1 - Organização anatômica do estômago de ratos ...............................................18

Figura 2 - Organização histológica da mucosa gástrica...................................................19

Figura 3 - Fotomicrografia da interface colo-base da glândula gástrica de rato adulto .........21

Figura 4 - Esquema da ação do GR nos compartimentos intracelulares...............................26

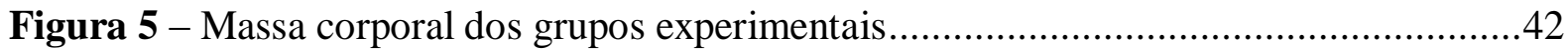

Figura 6 - Expressão dos genes Bhlha15, Msn, Gif, Pga5 e Pgc dos grupos experimentais .45

Figura 7 - Expressão dos genes $\mathrm{Nr3cl}$, Sgkl, Muc5ac, Muc6 e Futl dos grupos

experimentais

Figura 8 - Efeito do desmame precoce e do RU486 sobre a diferenciação das células mucosas do colo positivas para PASAB

Figura 9 - Efeito do desmame precoce e do RU486 sobre a diferenciação das células mucosas do colo positivas para lectina GSII 50

Figura 10 - Efeito do desmame precoce e do RU486 sobre células mucosas do colo imunomarcadas para mucina 6

Figura 11 - Efeito do desmame precoce e do RU486 sobre células imuno-marcadas para

Mist1

Figura 12 - Efeito do desmame precoce e do RU486 sobre células zimogênicas imunomarcadas para pepsinogênio $\mathrm{C}$ 57

Figura 13 - Esquema dos principais resultados obtidos no estudo .66 


\section{LISTA DE TABELAS}

Tabela 1 - Sequência de oligonucleotídeos iniciadores utilizados nos ensaios com Power

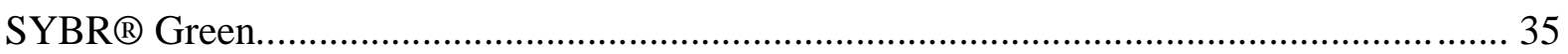

Tabela 2 - Ensaios TaqMan® usados para análises de expressão gênica............................. 36

Tabela 3 - Resumo dos resultados obtidos pela técnica de RT-PCRq mostrando os efeitos do DP e do bloqueio da ação da corticosterona com RU486 para os grupos do estudo 42

Tabela 4 - Massa corpórea (g) dos animais por grupo de estudo no momento da eutanásia. 47 


\section{LISTA DE ABREVIATURAS E SIGLAS}

A

$\mathrm{AB}$

ACTH

ANOVA

ARU

$\mathrm{C}$

cDNA

CMC

CMS

$\mathrm{CPZ}$

$\mathrm{CZ}$

DAB

DAPI

DEPC

DNA

dNTP

DP

DPRU

EDTA

EGF

EGFR

FITC

GR

GRE

GSII

$\mathrm{HE}$

i.p.

MAPK

MR

OMS

PASAB

PBS

PCR

PCRq

PGC

RNA

RNAm

RT

RT-PCRq

SGK1

TA

TAE

TGF- $\alpha$

TNF- $\alpha$
Amamentado

"Alcian Blue"

Hormônio adrenocorticotrófico

Análise de variância

Amamentado tratado com RU486

Controle

Ácido desoxirribonucleico complementar

Célula mucosa do colo

Célula mucosa superficial

Célula pré-zimogênica

Célula zimogênica

3,3'tetra-hidrocloreto de diaminobenzidina

4',6-diamidino-2-fenilindol

Dietilpirocarbonato

Ácido desoxirribonucleico

Desoxinucleotídeo trifosfato

Desmame precoce

Desmame precoce tratado com RU486

Ácido etilenodiaminotetracético

Fator de crescimento epidermal

Receptor do fator de crescimento epidermal

Isotiocianato de fluoresceína

Receptor de glicocorticoides

Elemento responsivo aos glicocorticoides

Griffonia simplicifolia

Hematoxilina e eosina

Intraperitoneal

Proteína quinase ativada por mitógeno

Mineralo-corticoide

Organização Mundial de Saúde

Ácido periodico Reativo de Schiff e Alcian Blue

Tampão fosfato salina

Reação em cadeia da polimerase

Reação quantitativa em cadeia da polimerase

Pepsinogênio C

Ácido ribonucleico

Ácido ribonucleico mensageiro

transcriptase reversa

Reação quantitativa em cadeia da polimerase com transcriptase reversa

Quinase induzida por soro e glicocorticoide 1

Temperatura ambiente

Tris acetato - EDTA

Fator de crescimento transformante alfa

Fator de necrose tumoral 


\section{SUMÁRIO}

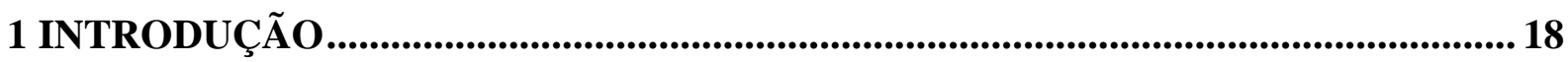

1.1 Epitélio gástrico ..................................................................................................................... 18

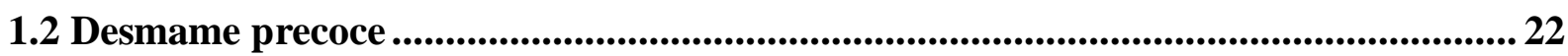

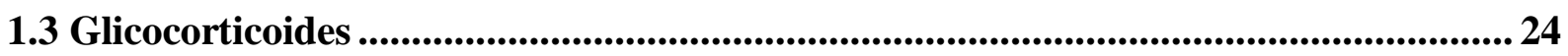

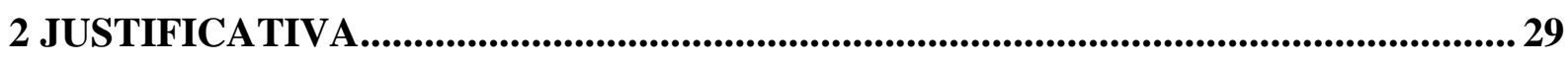

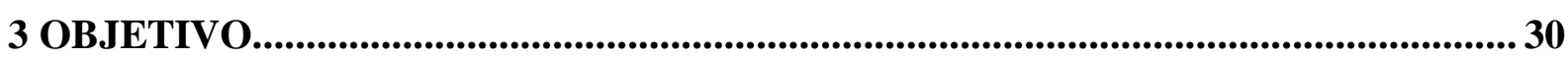

4 MATERIAL E MÉTODOS ............................................................................ 31

4.1 Animais e desmame precoce ............................................................................................31

4.2 Tratamento com RU486 ................................................................................................... 31

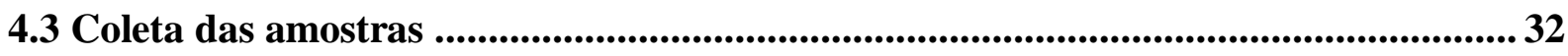

4.3.1 Coleta para as análises de PCR quantitativo ..................................................................... 32

4.3.2 Coleta para as análises de histoquímica e imuno-histoquímica ......................................33

4.4 RT-PCRq............................................................................................................................33

4.4.1 Extração de RNA .........................................................................................................33

4.4.2 Síntese de cDNA - reação da Transcriptase Reversa $(\mathrm{RT})$...............................................34

4.4.3 Amplificação do DNA - Reação em cadeia da polimerase (PCR) .................................. 34

Concentração de oligonucleotídeos ...........................................................................................35

4.5 Histoquímica para detecção de glicoproteínas ...................................................................36

4.5.1 Ácido periódico Reativo de Schiff e Alcian Blue (PASAB) ..........................................36

4.5.2 Lectina Griffonia simplicifolia II (GSII) ...........................................................................36

4.6 Imuno-histoquímica e quantificação das células imunomarcadas .................................37

4.6.1 Mucina 6 ........................................................................................................................... 37

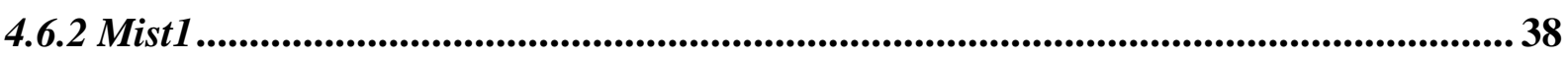

4.6.3 Pepsinogênio C (PGC) .........................................................................................................38

4.7 Captura de imagens ......................................................................................................... 39

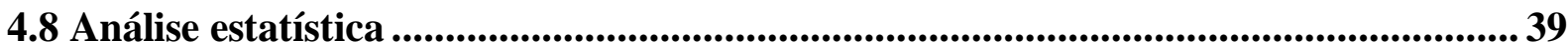

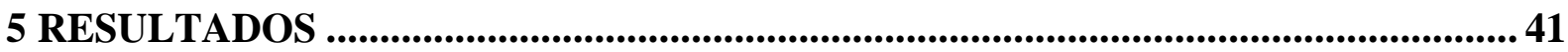

5.1 Massa corpórea dos animais ........................................................................................... 41

5.2 Avaliação de genes ligados à diferenciação do epitélio gástrico e à ação da corticosterona................................................................................................................... 43

5.3 Avaliação da população de células mucosas do colo (CMC) …………………………... 47

5.4 Avaliação da população de células imuno-marcadas para Mist1 ...................................53 
5.5 Avaliação da população de células imuno-marcadas para PGC .................................. 56

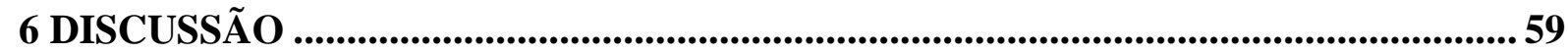

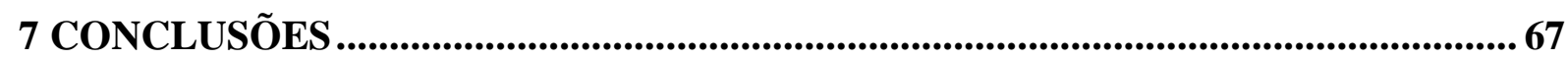

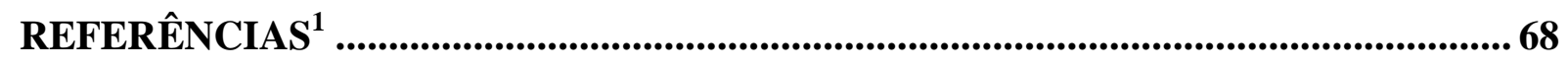




\section{INTRODUÇÃO}

\subsection{Epitélio gástrico}

O estômago de roedores é subdividido em três regiões histologicamente distintas: 1) Adjacente ao esôfago, temos a córnea que é formada por epitélio queratinizado e a ela seguem-se duas porções glandulares; 2) O corpo, porção mediana e a principal responsável pelo processo digestivo; 3) E o antro, que é formado por glândulas baixas com fossetas bem desenvolvidas ${ }^{1}$, conforme esquematizado na Figura $1^{2}$.

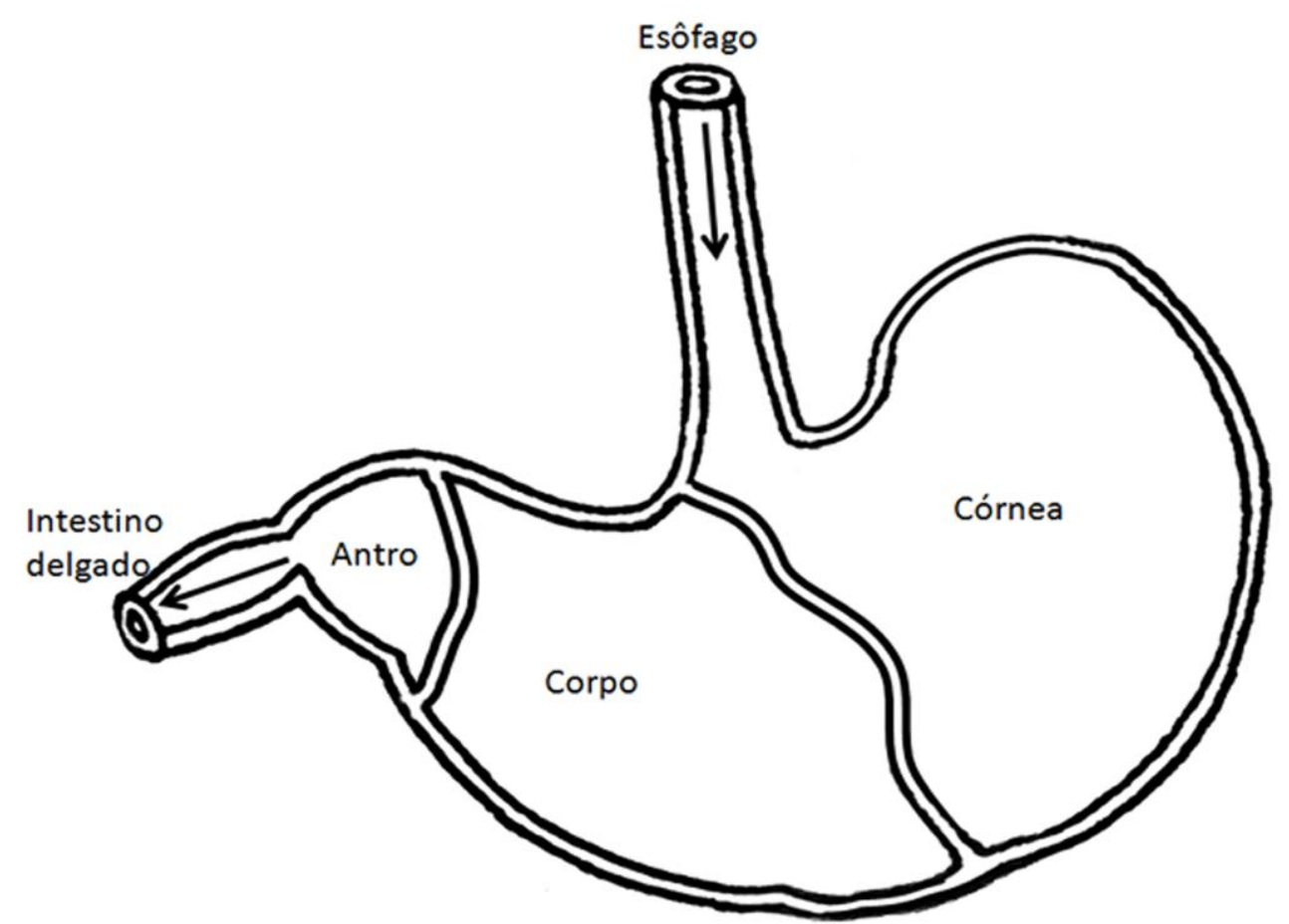

Figura 1 - Organização anatômica do estômago de ratos. O estômago está organizado em regiões histologicamente distintas: córnea, corpo e antro. As setas indicam o caminho feito pelo bolo alimentar. Fonte: Fiore (2013).

A mucosa da região do corpo gástrico é formada por longas glândulas tubulares que se abrem em fossetas, sendo a porção glandular subdividida em istmo, colo e base ${ }^{1}$ (Figura 2). A fosseta é recoberta por células mucosas superficiais, enquanto que no istmo, encontramos principalmente células tronco e células pouco diferenciadas. Na região do colo, podemos observar a presença de células mucosas do colo (CMC). Já na base da glândula, vemos principalmente células zimogênicas $(\mathrm{CZ})$. As células parietais ficam distribuídas por toda a glândula, enquanto que as enteroendócrinas são encontradas, em maior parte, na base ${ }^{3 ; 4}$. 


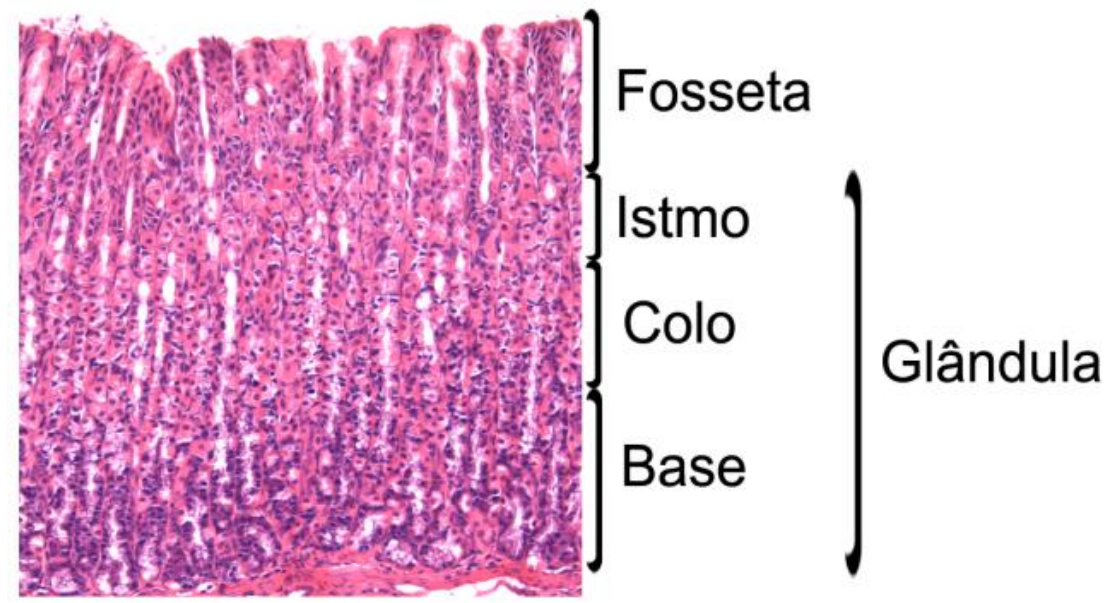

Figura 2 - Organização histológica da mucosa gástrica. Fotomicrografia da mucosa gátrica de rato de 30 dias corada em HE. Aumento original: 20x.

Todas essas populações são originadas por células tronco localizadas na interface istmocolo, onde encontramos o principal nicho responsável pela renovação da mucosa gástrica 5; 6; 7; 8; 9 . Dessas células tronco surgem células: pré-mucosas superficiais que migram para a fosseta e se diferenciam em células mucosas maduras; pré-parietais, que apresentam migração bidirecional e geram as células parietais maduras; e células pré-mucosas do colo que se deslocam para a região do colo onde irão formar as CMC. Sabe-se que parte dessas células continua migrando até a base onde se diferenciam em células pré-zimogênicas (CPZ) e posteriormente, em $\mathrm{CZ}^{\text {7;8;10;11;12. }}$

Como mencionado anteriormente, o principal nicho de células tronco, que garante a renovação do epitélio gástrico, fica localizado na interface istmo-colo. Entretanto, outro nicho localizado na base da glândula gástrica foi descrito recentemente: células tronco $\operatorname{Lgr}^{+} \mathrm{e}$ células tronco Troy ${ }^{+}$. As células $\mathrm{Lgr}^{+}$também são encontradas no intestino e as $\mathrm{Troy}^{+}$podem ser consideradas "células tronco de reserva", ativadas em situações especiais, como injúria grave do tecido ${ }^{9 ; 13}$.

O epitélio gástrico, em ratos, atinge seu completo estágio de maturação durante a terceira semana de vida pós-natal, período que coincide com a etapa de transição alimentar ${ }^{14}$ 15. A partir do $14^{\circ}$ dia de vida, os filhotes passam a se alimentar de ração juntamente com o leite materno, sendo que no $21^{\circ}$ dia é feito o desmame em biotério. Embora a presença dos principais tipos celulares que compõem a glândula gástrica (células parietais, células mucosas superficiais, CMC e CZ) já possa ser detectada em filhotes ao nascerem, essas células ainda são bastante imaturas e apresentam baixa capacidade funcional ${ }^{16}$. Na primeira semana de vida, a maturação das células parietais aumenta rapidamente, entretanto para os outros tipos 
celulares esse processo de desenvolvimento acontece mais lentamente, ao redor da terceira semana de vida pós-natal ${ }^{14 ; 16}$.

A mucosa gástrica é recoberta por um muco espesso formado em maior parte por mucinas ${ }^{17 ; 18}$. Esse muco protege o estômago contra agentes patogênicos ${ }^{19}$, contra a ação do pH ácido, produzido pelas células parietais, e contra a ação das enzimas digestivas, secretadas pelas $\mathrm{CZ}^{20}$. As mucinas são glicoproteínas de alto peso molecular com ligações Oglicosídicas ${ }^{21 ; 22}$. No estômago, as células mucosas superficiais recobrem toda a fosseta e são as responsáveis por secretar a mucina $5 \mathrm{AC}$, já as CMC secretam a mucina $6^{22 ; 23}$.

As CMC são pequenas, triangulares, localizadas na região de colo da glândula entre as células parietais e apresentam o citoplasma repleto de mucina ${ }^{22}$. Vários pesquisadores já demonstraram a origem dessas células a partir de células tronco gástricas 5; 7;8;9 e também evidenciaram a existência de uma linhagem intermediária entre as $\mathrm{CMC}$ e $\mathrm{CZ}$, as células prézimogênicas. Essas células possuem grânulos de secreção mucosos, como a as CMC, e grânulos de secreção serosa, como as CZ, além de grânulos mistos ${ }^{10 ; 11 ; 12 ; 14 ; 24}$ (Figura 3). 


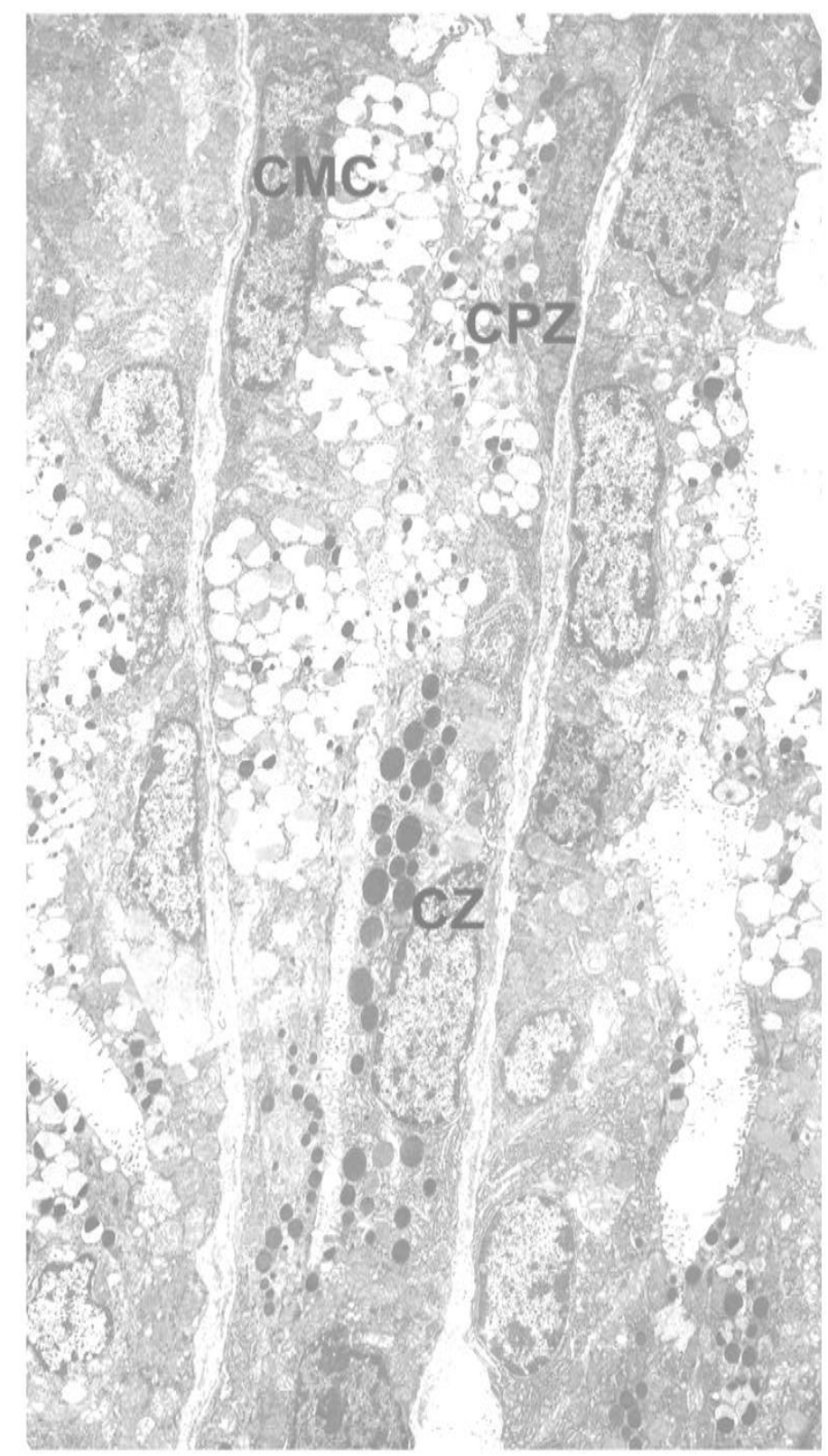

Figura 3 - Fotomicrografia da interface colo-base da glândula gástrica de rato adulto. Observa-se, no alto, células mucosas do colo (CMC) com citoplasma repleto de grânulos fracamente elétron-densos, células pré-zimogênicas $(\mathrm{CPZ})$ com grânulos de secreção mistos e, mais abaixo células zimogênicas com grânulos elétron-densos no citoplasma. Obtida por Eliana Parisi Alvares em microcópio eletrônico de transmissão. Aumento original 2500x.

Para que o aparato secretor celular produza uma secreção serosa, é necessária a ação do fator de transcrição Mist1 25;26;27. Este fator de transcrição, além de promover a transcrição de genes necessários para a formação do aparato de secreção serosa, age também sobre genes que regulam o formato celular e o posicionamento ápico-basal de organelas citoplasmáticas, modificando a morfologia de uma célula triangular - CMC - para uma célula mais cuboide e com retículo endoplasmático mais desenvolvido $-\mathrm{CZ}^{28}$. 
As CZ localizam-se na base da glândula gástrica e, em ratos, secretam pepsinogênio e fator intrínseco ${ }^{29}$. O pepsinogênio, sob a ação do pH ácido encontrado na luz do estômago, é convertido à pepsina, principal enzima digestória ${ }^{16}$. O tipo de pepsinogênio a ser secretado varia de acordo com o estágio de desenvolvimento do animal ${ }^{30 ; 31}$, sendo que em adultos o principal tipo é o pepsinogênio $\mathrm{C}$, codificado pelo gene $P c g$, enquanto que em filhotes encontramos em maior quantidade o pepsinogênio imaturo, codificado pelo Pga5. Já a produção de fator intrínseco (Gif) varia apenas de maneira quantitativa ${ }^{14}$.

Além dos produtos de secreção, que identificam a diferenciação dessas células, a família de proteínas ERM também apresenta uma distribuição específica no epitélio gástrico, o que pode contribuir para avaliação do desenvolvimento do estômago ${ }^{32}$. A família ERM é formada pelas proteínas ezrina, radixina e moesina que fazem a ligação da membrana plasmática ao citoesqueleto de actina ${ }^{33 ; 34}$. A ezrina é encontrada em células parietais, participando da organização dos canalículos formados pela membrana plasmática, que apresenta os transportadores de íons que formarão o ácido clorídrico ${ }^{35}$. Já a moesina faz a ligação da membrana plasmática ao citoesqueleto em $\mathrm{CMC} \mathrm{CZ}^{32}$.

O grau de maturação do epitélio gástrico de ratos pode ser avaliado segundo a presença das populações celulares que formam a glândula gástrica, identificadas pelos marcadores aqui descritos, entre outros. A completa diferenciação de CMC e CZ corresponde a uma das etapas mais tardias desse processo de maturação e a detalhada caracterização da presença desses tipos celulares é de grande importância no nosso modelo.

\subsection{Desmame precoce}

É chamada de período de desmame (ou aleitamento suplementado) a etapa em que os filhotes reduzem a ingestão de leite materno e começam a consumir os mesmos alimentos ofertados aos indivíduos adultos (alimentos sólidos), é uma etapa de alimentação mista. Esta mudança de dieta é feita de maneira gradativa até que cesse completamente a ingestão de leite materno e o indivíduo é considerado desmamado. A Organização Mundial de Saúde (OMS) estabelece que o aleitamento materno exclusivo deva acontecer até que a criança complete seis meses de idade, portanto a introdução de qualquer outro alimento antes deste período pode ser considerada precoce ou antecipada ${ }^{36}$.

Os benefícios da amamentação já são bastante conhecidos. Para as mães, esta prática está associada à menor prevalência de hipertensão arterial, diabetes tipo 2, hiperlipidemia e doenças cardiovasculares durante o primeiro ano de vida do lactente ${ }^{37}$. E a alimentação dos 
bebês com fórmulas infantis, nos primeiros meses de vida, pode aumentar a vulnerabilidade ao surgimento de infecções, principalmente as que acometem o trato digestório, como as diarréias infecciosas ${ }^{38}$.

Em ratos, o período de amamentação ocorre naturalmente até o $28^{\circ}$ dia de vida pós-natal e o aleitamento materno exclusivo acontece até o $14^{\circ}$ dia. É ao redor deste dia que diversos processos fisiológicos ocorrem, como a abertura dos olhos, a regulação termogênica, o desenvolvimento do paladar, a maturação da língua e a capacidade de urinar e defecar sem o auxílio materno, o que possibilita ao filhote uma maior independência dos cuidados maternos e o reconhecimento de uma nova fonte de alimento, a ração. Para fins experimentais, no $21^{\circ}$ dia acontece o desmame em biotério. Já o desmame precoce (DP) ocorre através da abrupta interrupção do aleitamento materno, geralmente aos 15 dias de vida pós-natal ${ }^{39 ; 40}$.

Durante o desmame, a principal fonte de macro-nutrientes é modificada com a substituição da ingestão do leite materno, rico em lipídeos, pelo consumo da ração, rica em carboidratos ${ }^{40}$. O leite materno é a principal fonte de alimento do recém-nascido, e através dele é estabelecido um elo entre o organismo da mãe e da prole. A adequada ingestão do leite materno garante ao animal quantidades corretas de diversos hormônios e fatores de crescimento essenciais que são secretados pela mãe. Portanto, o aleitamento deve ocorrer até que o filhote seja capaz de produzir suas próprias moléculas biologicamente ativas, e mudanças neste padrão alimentar podem provocar perturbações fisiológicas no desenvolvimento do animal $^{41 ; 42 ; 43 ; 44 ; 45}$. O modelo de DP gera uma antecipação na maturação de vários órgãos e sistemas, como o aumento prematuro na atividade enzimática da sacaraseisomaltase e da ornitina descarboxilase no intestino ${ }^{46 ; 47}$. O desmame precoce também modifica o perfil de resposta proliferativa do epitélio gástrico frente a estímulos. Por exemplo, em filhotes desmamados precocemente, o jejum causa inibição da divisão celular, resposta normalmente encontrada em adultos, ou seja, esse padrão alimentar induz o aparecimento prematuro de características presentes em ratos adultos ${ }^{48}$.

Estudos de nosso laboratório evidenciaram que quando comparado à amamentação regular, o DP provoca aumento da proliferação celular epitelial gástrica e da diferenciação de CMC pela ação do EGFR ${ }^{49 ;}$. Além disso, animais desmamados precocemente apresentam uma modificação da distribuição do fator de crescimento transformante- $\beta 3$ e das células produtoras de ghrelina no estômago ${ }^{51 ; 52}$. Vimos também que o DP é capaz de elevar os níveis de corticosterona plasmática nos primeiros dias de tratamento, alterando a atividade desse hormônio na mucosa gástrica de filhotes ${ }^{53}$. E outros pesquisadores demonstraram que ratos desmamados precocemente apresentam disfunção e má-formação da barreira intestinal, 
redução da expressão de fosfatase alcalina no intestino, cinco vezes mais incidência de

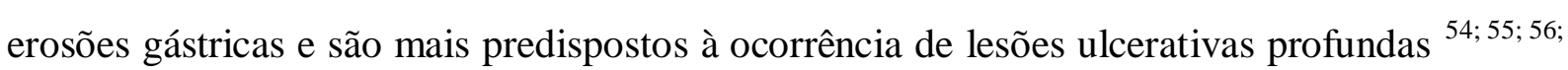
57.

Em nosso modelo, o DP é realizado por meio da separação da nutriz de sua prole, interrompendo não apenas a amamentação, mas também o constante cuidado materno ${ }^{46 ; 48}$. Vários estudos mostraram que o DP produz alterações comportamentais como o aumento da sensação de medo e vocalização precoce ${ }^{58 ; 59}$. O DP também pode modificar o cuidado que as fêmeas que foram submetidas a essa mudança de dieta irão ofertar à sua prole, já que elas mesmas vivenciaram esta privação maternal ${ }^{59}$. Sabe-se que a falta de cuidados maternos, nas primeiras semanas de vida, pode alterar a atividade do eixo hipotálamo-pituitária-adrenal (HPA), o principal sistema de resposta ao estresse ${ }^{60 ; 61}$. A separação materno-neonatal, por si só, aumenta a secreção de corticosterona ${ }^{62}$ e induz mudanças epigenéticas próximas à região promotora do gene $N r 3 c 1$, que codifica o receptor de glicocorticoides (GR) ${ }^{63}$.

Vários estudos apontam a fase de desmame como uma etapa crítica para o desenvolvimento e funcionamento de vários órgãos em indivíduos adultos, pois perturbações no período de desmame são capazes de induzir mudanças deletérias permanentes; a manutenção dessas mudanças faz parte do conceito de programação ${ }^{64 ; 65 ; 66 ; 67 ; 68}$. Entretanto, apenas recentemente, os avanços da biologia molecular puderam comprovar que o estresse neonatal induz modificações epigenéticas ${ }^{63}$, reforçando a importância de estudos desenvolvidos sobre esta fase da infância, e sobre a ontogênese de doenças, que acometem indivíduos adultos.

\subsection{Glicocorticoides}

Os hormônios glicocorticoides são esteroides produzidos e secretados pelo córtex da glândula adrenal. Esses hormônios fazem a mediação de diversos processos fisiológicos e respondem às situações de estresse ${ }^{69}$. Os glicocorticoides (GCs) (principalmente os sintéticos) são bastante utilizados como anti-inflamatórios e no tratamento de reações alérgicas devido a sua ampla atividade sobre o sistema imune ${ }^{70}$.

A elevação dos níveis de GCs ocorre em resposta à ativação do eixo HPA. Após a uma situação de estresse, o sistema nervoso simpático libera hormônios que induzem a secreção pelo hipotálamo do hormônio liberador de corticotropina na microcirculação da hipofisária, que por sua vez produz o hormônio adrenocorticotrófico (ACTH). Este último age sobre as células do córtex da adrenal, induzindo a secreção dos hormônios GCs ${ }^{71 ; 72}$. 
Em roedores, o principal glicocorticoide é a corticosterona, cuja secreção passa por variações naturais ao longo do desenvolvimento dos animais. Na etapa pré-natal, por volta do $18^{\circ}$ e $20^{\circ}$ dia gestacional, ocorre o primeiro pico de secreção hormonal, coincidindo com o final da gestação. Posteriormente, entre o $14^{\circ}$ e $24^{\circ}$ dia de vida pós-natal, os níveis de corticosterona vão aumentando gradativamente em paralelo ao quadro de maturação morfofisiológico. Como dito anteriormente, é neste período que ocorre a fase final de maturação do epitélio gástrico, a abertura dos olhos, a maturação morfológica da língua, entre outros processos ${ }^{39 ; 40 ; 73}$. Os hormônios GCs agem como reguladores do desenvolvimento ${ }^{74}$, e modificações na dieta de animais em desenvolvimento, como o jejum, DP, e separação materno- neonatal aumentam a secreção de corticosterona ${ }^{46 ; 53 ; 75 ; 76 ; 77 . ~}$

Os glicocorticoides agem nas células através da ligação com receptores citoplasmáticos de dois tipos: os receptores mineralo-corticoides (MRs) e os receptores de glicocorticoides (GRs) ${ }^{78 ; 79}$. Ambos receptores são encontrados ao longo do trato gastrintestinal, sendo a distribuição de MR muito baixa no estômago, e mais abundante no intestino, enquanto o GR é encontrado em todos os tipos celulares do epitélio gástrico ${ }^{76 ; 80 ; 81}$.

O GR inativo é encontrado no citoplasma das células ligado a um complexo multiproteico. Após a ligação da corticosterona ao receptor, o complexo multiproteico se dissocia e ocorre a formação de um dímero de GR, que transloca para o núcleo celular onde agirá como um fator de transcrição. Dentro do núcleo, o receptor se liga a sequências específicas do DNA, chamadas elementos responsivos aos glicocorticoides (GREs) e promove a transcrição dos genes-alvo. Esta é a via de ação clássica em que o GR interage com os GREs positivos. A via dos GREs negativos é ativada quando o dímero de GR, ligado ao glicocorticoide, passa para o núcleo celular e interage com outros fatores de transcrição e moléculas co-repressoras. Esta via reduz ou impede a transcrição de moléculas envolvidas em processos inflamatórios e componentes de ativação do eixo $\mathrm{HPA}^{79 ; 82}$. As vias de atividade do GR estão representadas na Figura ${ }^{83}$. 


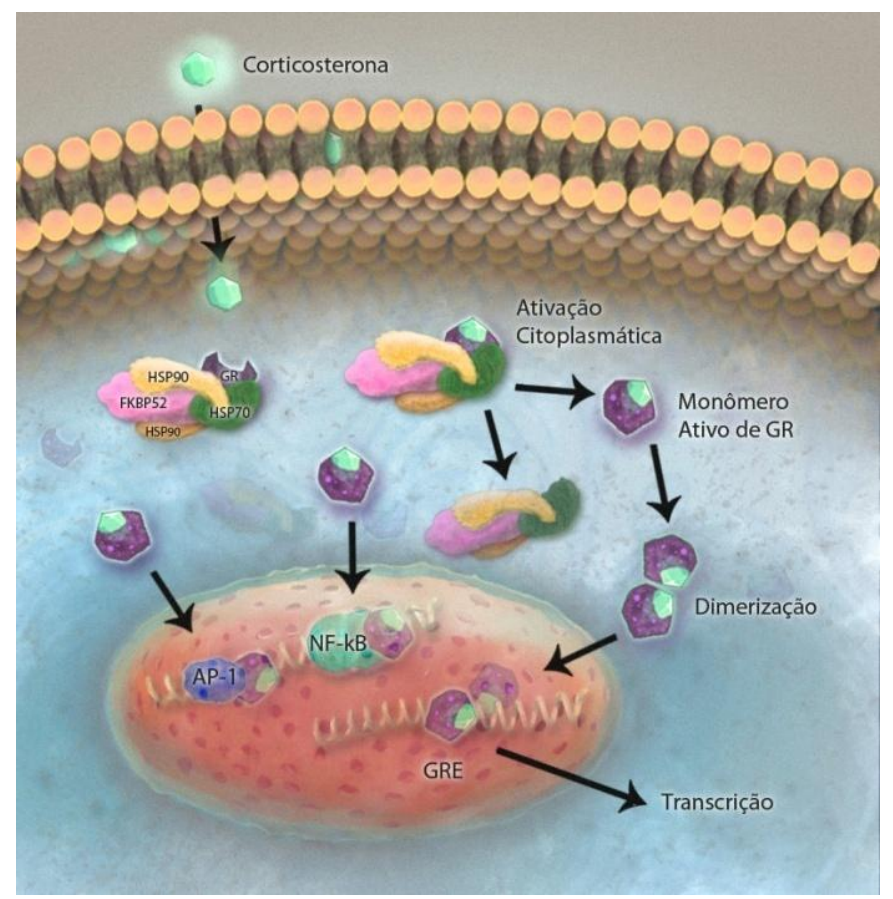

Figura 4 - Esquema da ação do GR nos compartimentos intracelulares. Fonte: Figueiredo (2010).

Umas das ferramentas mais utilizadas para a avaliação dos efeitos dos GC é o tratamento com o antagonista de GR, RU486 (ou mifepristona). Trata-se de um esteroide análogo desenvolvido pela companhia farmacêutica Roussel-Uclaf (Romainville, França), em meados de 1980, como parte de um projeto de pesquisa para a concepção de compostos antiglicocorticoides ${ }^{84 ; 85}$. Secundariamente, descobriu-se que o RU486 também possuía uma ação antiprogestágena. Combinado com a prostaglandina E1, como no sintético misoprostol, resulta em aborto com uma taxa de sucesso próxima a 100\%. A mifepristona apresenta três principais efeitos farmacológicos: o endometrial, o gonadotrófico e o adrenocortical. O RU486 tem sido testado no tratamento de casos clínicos, como o câncer de mama e próstata, endometriose, leiomiomatose e a síndrome de Cushing ${ }^{86}$.

O antagonista inibe ação dos glicocorticóides em três etapas: No meio extracelular, o RU486 compete com a corticosterona pela ligação ao GR, com uma afinidade de três a quatro vezes maior que a da dexametasona. Ao ligar-se ao GR, a mifepristona estabiliza a interação entre o receptor e o complexo multiproteico, impedindo sua dissociação e evitando a translocação do GR para o núcleo. Embora alguns receptores, mesmo complexados ainda possam se translocar para o núcleo da célula, o GR ligado ao antagonista apresenta baixa afinidade pelo DNA ${ }^{85 ; 87}$. O RU486 possui uma meia-vida plasmática longa, podendo atingir 
90 horas, e desencadeia um efeito dose-dependente, ${ }^{84}$. A mifepristona é um composto com ação antiprogesterona e antiglicocorticoides. No entanto, a presença de receptores de progesterona no epitélio gástrico é baixa, o que assegura que os efeitos desencadeados pela droga sejam majoritariamente devido a sua ação efeito antiglicocorticoide ${ }^{85}$.

O RU486 apresenta ação central e periférica. No sistema nervoso central, o RU486 bloqueia os receptores de GCs presentes no hipotálamo, interferindo no mecanismo de feedback negativo que regula a secreção hormonal. Como consequência, ocorre um aumento dos níveis plasmáticos de ACTH e de corticosterona ${ }^{86}$. No estômago, o efeito da mifepristona é específico, uma vez que o antagonista não se liga aos receptores de mineralocorticoides (MR) ${ }^{88 ; 89}$, e os GRs são preferencialmente ocupados pelo RU486 ${ }^{90}$.

Como já mencionamos, são muitas as funções exercidas pelos hormônios GCs, o que os torna objeto de vários estudos. Ao longo dos anos, fez-se necessário o conhecimento de moléculas capazes de validar os efeitos dos GCs, moléculas alvo. Um deles é a enzima serina/treonina- quinase induzida por soro e glicocorticoides 1 (SGK1). Esta enzima é conhecida por mediar a ação de GC em vários tecidos ${ }^{91}$, e tem alta expressão no estômago ${ }^{92}$. Originalmente, o gene Sgk1 foi clonado em resposta precoce aos GCs ${ }^{93}$, e sua expressão no estômago e intestino aumenta sob efeito desses hormônios ${ }^{92 ; 94 ; 95}$. Sabe-se, por exemplo, que o tratamento de células derivadas de tumor de intestino com dexametasona induz a expressão de Sgk1 após 30 min e a mantém elevada por até 24 hs, entretanto este efeito é abolido pela ação do RU486 ${ }^{94}$.

No estômago, somado aos efeitos sobre a SGK1, os GC aceleram a diferenciação das células zimogênicas. O tratamento com hidrocortisona provoca o aparecimento precoce do pepsinogênio, além de aumentar a sua atividade ${ }^{96 ; 97}$.

Os GCs também exercem importante papel sobre as glicoproteínas formadoras do

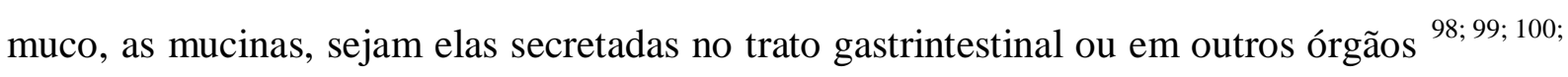
101. Entretanto, a ação dos GCs sobre essa classe de proteínas é bastante controversa: em células epiteliais nasais, o tratamento com dexametasona aumenta a expressão das mucinas 1 e 8 , enquanto reduz a expressão de $M u c 5 b^{98}$. Os GCs também elevam expressão e atividade de enzimas de glicosilação no intestino ${ }^{102}$.

Estudos de nosso laboratório sobre os efeitos dos GCs no epitélio gástrico de ratos em amamentação mostraram que o aumento dos níveis endógenos de corticosterona causado pelo estresse pode desencadear respostas diferentes da administração de hormônios exógenos, indicando que a atividade esteroidal é diferente, dependendo da fonte de GCs. Assim, enquanto o jejum alimentar (condição que provoca aumento da secreção de corticosterona) 
induz a proliferação da mucosa gástrica, o tratamento com hidrocortisona inibe a mesma resposta $^{48 ; 75 ; 103}$. Esses trabalhos nos ajudam a reforçar a importância sobre a avaliação dos efeitos do estresse sobre animais que ainda estão em desenvolvimento. 


\section{JUSTIFICATIVA}

A OMS recomenda que o desmame de bebês seja realizado de maneira gradativa após os seis meses de idade ${ }^{36}$. Assim, o período de amamentação e a fase de desmame são críticos para o desenvolvimento de vários órgãos, dentre eles o estômago ${ }^{14 ; 15 ; 65 ; 67}$. Nesse órgão, os peptídeos biologicamente ativos presentes no leite materno entram em contato direto com o epitélio gástrico, e regulam sua ontogênese ${ }^{15 ; 40 ; 43 ; 49 ; 104}$. Modificações na transição do padrão de alimentação levam a mudanças importantes, dentre elas, a secreção de GCs, cujos níveis também estão relacionados com a maturação de órgãos e sistemas ${ }^{46 ; 53 ; 74}$.

Dessa forma, o desmame precoce constitui um processo, no qual todas as diferentes mudanças no padrão de crescimento podem interferir no desenvolvimento geral, caracterizando uma plasticidade. A corticosterona pode ter função preponderante neste mecanismo de regulação, e a plasticidade celular pode contribuir para que os diferentes estímulos, positivos ou negativos sejam adquiridos até de maneira irreversível, provocando modificações epigenéticas ${ }^{64 ; 65}$.

Portanto, faz-se necessário um maior conhecimento a respeito dos efeitos desencadeados pelo DP, em especial na mucosa gástrica. Além de contribuir para o melhor entendimento do crescimento gástrico ao longo do desenvolvimento pós- natal, a diferenciação da linhagem de CMC e CZ está atualmente no cerne dos estudos de lesões prétumorais, uma vez que na carcinogênese gástrica, toda a maturação celular se torna aberrante. Assim, nosso estudo visa contribuir com informações da pesquisa básica para áreas aplicadas da oncologia gástrica e pediatria. 


\section{OBJETIVO}

Nosso objetivo foi investigar a ação da corticosterona sobre o padrão de maturação do epitélio gástrico de ratos submetidos ao desmame precoce, e avaliar se os efeitos promovidos são mantidos até o início da vida adulta. Mais especificamente, utilizamos o antagonista de corticosterona RU486 durante o desmame precoce para estudar:

1) a expressão de genes envolvidos na diferenciação de células secretórias do epitélio gástrico;

2) a diferenciação e a distribuição de células mucosas do colo e células zimogênicas;

3) se os efeitos desencadeados pelo padrão alimentar associado ao hormônio são mantidos no início da vida adulta. 


\section{MATERIAL E MÉTODOS}

\subsection{Animais e desmame precoce}

Utilizamos ratos albinos de ambos os sexos (Rattus norvegicus, linhagem Wistar), mantidos com acesso ad libitum à ração e água, sob ciclo de 12/12 horas de claro/escuro, com temperatura e exaustão controladas no Biotério do Departamento de Biologia Celular e do Desenvolvimento do Instituto de Ciências Biomédicas da Universidade de São Paulo (ICB USP). Os protocolos utilizados foram aprovados pela Comissão de Ética no Uso de Animais (CEUA 86/2008; 18/2015).

Fêmeas foram acasaladas e mantidas em gaiolas individuais. $\mathrm{O}$ dia do nascimento dos filhotes foi anotado como zero, e no $2^{\circ}-3^{\circ}$ dia de vida pós-natal, as ninhadas foram reduzidas a 8-9 filhotes que permaneceram com suas mães até o $15^{\circ}$ dia. Nesta idade, dividimos os animais em 4 grupos: amamentado controle (A), amamentado tratado com RU486 (ARU), desmame precoce (DP) e desmame precoce tratado com RU486 (DPRU).

Os ratos dos grupos DP foram separados de suas mães e transferidos para outra gaiola, onde a dieta passou a ser uma pasta de ração, disponível 24 horas/dia até o $21^{\circ}$ dia de vida ${ }^{48}$. Duas vezes ao dia, esses filhotes também receberam o alimento pastoso e água através de pipeta descartável, e foram massageados na região abdominal, para facilitar a excreção de urina e fezes. Esse tratamento ocorreu até que os animais completassem 19 dias de vida pósnatal e já conseguissem se alimentar dos pellets de ração. Os animais dos grupos A e ARU permaneceram com suas mães, sendo amamentados normalmente, até o momento da eutanásia. A massa corpórea dos animais foi monitorada ao longo de todo o experimento.

\subsection{Tratamento com RU486}

Neste estudo, avaliamos o papel da corticosterona na diferenciação do epitélio gástrico através do tratamento com o RU486 (Mifepristona, Sigma-Aldrich, St. Louis, MO, EUA), que bloqueia a atividade do receptor de glicocorticoides (GR). O RU486 é um composto esteroide com ação antiprogesterona e antiglicocorticoides. Todavia, conforme mencionado anteriormente, a reduzida distribuição de receptores de progesterona no epitélio gástrico, assegura que os efeitos desencadeados pela droga são majoritariamente devido ao efeito antiglicocorticoide ${ }^{85}$. 
O RU486 apresenta uma meia-vida plasmática longa, que atinge 90 horas ${ }^{84}$. Para comprovar a eficácia deste tratamento avaliamos a expressão de $S g k 1$ em nossas amostras, conforme descrito abaixo. Cabe ressaltar que a SGK1 é uma quinase serina/treonina originalmente clonada como um gene de resposta precoce aos GCs ${ }^{93}$, porém esse efeito é abolido pela ação do RU486 ${ }^{94}$.

Os grupos que receberam o tratamento com antagonista de corticosterona foram injetados com RU486 (10 mg/Kg de massa corpórea diluído em óleo de milho na concentração de $2,5 \mathrm{mg} / \mathrm{mL}$ ) i.p. às $17: 00$ no $15^{\circ}$ dia de vida pós-natal. $\mathrm{O}$ dia e horário da injeção de RU486 foram estabelecidos com base em resultados de nosso laboratório ${ }^{53}$ e dados da literatura que mostram a ocorrência de um pico de corticosterona plasmática no entardecer do dia seguinte ao início do DP $\left(16^{\circ}\right.$ dia $){ }^{46}$. Os animais controle foram tratados no mesmo horário com o veículo.

\subsection{Coleta das amostras}

A coleta do estômago e eutanásia dos animais foram realizadas às $10 \mathrm{~h} 00$ dos dias 17 , 18 (filhotes) e 30 (adultos-jovens), sob anestesia com injeção i.p. de cloridratos de ketamina e xilazina (1:1, Anasedan e Dopalen, Vetbrands, Paulínia, SP, Brasil) em dose excessiva (0,5 $\mathrm{ml} / 100$ g de massa corpórea). O estômago foi aberto pela curvatura menor, esticado em cortiça e submetido a diferentes protocolos, de acordo com os ensaios aos quais as amostras seriam submetidas: reações de PCR quantitativo, análises morfológicas, e reações de imunohistoquímica.

\subsubsection{Coleta para as análises de PCR quantitativo}

As amostras para os ensaios de PCR quantitativo foram obtidas dentro dos parâmetros descritos acima, a partir de filhotes de 17 dias (para a avaliação da expressão gênica previamente a identificação de proteínas em cortes histológicos obtidos de animais de 18 dias) e adultos-jovens de 30 dias. O órgão, aberto pela menor curvatura e esticado em cortiça, foi lavado com água DEPC (Invitrogen, Carlsbad, CA, EUA) e submetido à raspagem para obtenção da mucosa gástrica, procedimento realizado sob microscópio estereoscópico (Zeiss, Oberkochen, Alemanha). O tecido obtido foi conservado em RNAlater (Ambion, Carlsbad, CA, EUA) e armazenado a $-80^{\circ} \mathrm{C}$ até o processo de extração do RNA. 


\subsubsection{Coleta para as análises de histoquímica e imuno-histoquímica}

O estômago coletado através do procedimento descrito acima, após ser esticado em cortiça, foi lavado com salina $0,9 \%$ e fixado por 4 horas em formaldeído $4 \%$, para avaliação da mucina 6 , ou formaldeído $10 \%$, para as outras reações imuno-histoquímicas e histoquímicas. Após este período, a amostra foi removida da cortiça e acomodada sobre papel cartão em um cassete plástico. O processo de fixação prosseguiu por mais 4 horas, quando então o cassete com o material coletado foi transferido para álcool $70^{\circ}$ até ser incluído em parafina. No momento da inclusão, o estômago coletado foi seccionado em três fragmentos, cada um contendo as três regiões do epitélio gástrico de roedores: córnea, corpo e antro.

Os cortes histológicos foram corados com hematoxilina e eosina (HE), previamente à realização das análises citadas, para controle da qualidade do material. Para as reações de histoquímica, utilizamos material obtido de animais de 17, 18 e 30 dias de vida pós-natal. Em estudos prévios as avaliações foram feitas na mucosa gástrica de ratos de 17 e 18 dias ${ }^{49}$, porém como nossos resultados preliminares não indicaram variação entre essas idades, as análises de imuno-histoquímica foram feitas a partir de ratos de 18 e 30 dias.

\subsection{RT-PCRq}

\subsubsection{Extração de RNA}

A extração do RNA, das amostras obtidas após raspagem da mucosa gástrica, ocorreu pelo método de TRIzol® (Ambion) combinado com PureLink® RNA Mini Kit (Ambion).

Conforme as especificações do fabricante, o raspado da mucosa gástrica conservado em RNAlater (Ambion) a $-80{ }^{\circ} \mathrm{C}$ foi transferido para um tubo de fundo chato contendo $1 \mathrm{~mL}$ de TRIzol® (Ambion) gelado. Realizou-se a homogeneização com auxílio de homogeneizador elétrico ULTRA-TURRAX® T10 (IKA, Staufen, Alemanha). Em seguida, acrescentou-se $200 \mu \mathrm{L}$ de clorofórmio (Merck, Darmstadt, Alemanha). Após agitação manual e incubação ( 3 min, TA), os tubos foram centrifugados a $12.000 \mathrm{~g}\left(15 \mathrm{~min}, 4{ }^{\circ} \mathrm{C}\right)$. Com a formação de três fases, foram transferidos $350 \mu \mathrm{L}$ da fase aquosa superior para um tubo de fundo cônico, e acrescidos $350 \mu \mathrm{L}$ de etanol (Merck, Darmstadt, Alemanha) $70^{\circ}$ livre de RNAse. Após agitação em vórtex, os $700 \mu \mathrm{L}$ (etanol e fase aquosa) foram colocados em um conjunto Spin (tubo Spin e tubo coletor) e centrifugados a $12.000 \mathrm{~g}$ (30 s, TA). O tubo coletor foi esvaziado, acrescentamos $700 \mu \mathrm{L}$ de tampão de lavagem I e centrifugamos a $12.000 \mathrm{~g}$ (30 
s, TA). Em seguida, trocamos o tubo coletor. Foram adicionados $500 \mu \mathrm{L}$ de tampão de lavagem II com etanol (Merck, Darmstadt, Alemanha), e esse passo foi seguido de centrifugação a $12.000 \mathrm{~g}$ (30 s, TA) e esvaziamento do tubo coletor por duas vezes. Após mais uma etapa de centrifugação a $12.000 \mathrm{~g}$ (1 min, TA), o tubo coletor foi descartado e o tubo Spin foi colocado em um tubo de recuperação. Adicionamos $30 \mu \mathrm{L}$ de água livre de RNAse e incubamos (1 min, TA). Posteriormente, centrifugamos a $12.000 \mathrm{~g}$ (2 min, TA). Oito $\mu \mathrm{L}$ da amostra restante foram então transferidos para um tubo contendo $8 \mu \mathrm{L}$ de água livre de RNAse, $1 \mu \mathrm{L}$ de tampão de DNase I 10 x e $1 \mu \mathrm{L}$ de DNase I (1Invitrogen, Carlsberg, CA, EUA). Incubamos (15 min, TA), acrescentamos $1 \mu \mathrm{L}$ de EDTA $25 \mathrm{mM}$ (Invitrogen) e aquecemos a $65^{\circ} \mathrm{C}(10 \mathrm{~min})$.

A quantificação do RNA foi realizada por espectrofotometria com caminho óptico de $0,1 \mathrm{~mm}$ e a análise da pureza das amostras extraídas ocorreu pela avaliação das razões entre as absorbâncias medidas a 260 e $280 \mathrm{~nm}$, e medidas a 260 e $230 \mathrm{~nm}$ (NanoDrop - Thermo Fisher Scientific, Waltham, MA USA) (Laboratório de Biologia Celular e Molecular - Prof ${ }^{a}$. Dra . Gláucia M. Machado-Santelli). A integridade do RNA foi testada em gel de agarose $1 \%$ com brometo de etídeo em tampão Tris acetato $40 \mathrm{mM}$ - EDTA $1 \mathrm{mM}$ (TAE) através da observação das bandas correspondentes às subunidades $30 \mathrm{~S}$ e $50 \mathrm{~S}$ do RNA ribossomal.

\subsubsection{Síntese de cDNA - reação da Transcriptase Reversa (RT)}

Para a síntese do cDNA, $3 \mu \mathrm{g}$ de RNA total, previamente tratados com DNase I, foram adicionados a $1 \mu \mathrm{L}$ de Oligo (dT) Primer com $2 \mu \mathrm{L}$ de água DEPC, seguido de incubação a 70 ${ }^{\circ} \mathrm{C}$ (10 min). Posteriormente, acrescentou-se $6 \mu \mathrm{L}$ de mistura contendo $3 \mu \mathrm{L}$ de Tampão FirstStrand $5 \mathrm{X}, 2 \mu \mathrm{L}$ de DTT $0,1 \mathrm{M}$ e $1 \mu \mathrm{L}$ de dNTP $10 \mathrm{mM}$, e incubou-se a $42{ }^{\circ} \mathrm{C}$ (5 min). Em seguida, adicionou-se $1 \mu \mathrm{L}$ de enzima SuperScript III RT $200 \mathrm{U} / \mu \mathrm{L}$ e a reação prosseguiu sob incubação a $42{ }^{\circ} \mathrm{C}(50 \mathrm{~min})$ e a $70{ }^{\circ} \mathrm{C}(15 \mathrm{~min})$. Por fim, foi adicionado1 $\mu \mathrm{L}$ de RNase H 2 $\mathrm{U} / \mu \mathrm{L}$ com incubação a $37{ }^{\circ} \mathrm{C}$ (20 min). Todos os reagentes utilizados nas etapas descritas eram da marca Invitrogen.

\subsubsection{Amplificação do DNA - Reação em cadeia da polimerase (PCR)}

As reações de PCR quantitativo foram conduzidas em termociclador StepOne Plus (Applied Biosystems, Carlsberg, CA, EUA) e os genes listados foram avaliados com oligonucleotídeos desenhados (Tabela 1) e usados em reação com Power SYBR® Green PCR 
Master Mix (Applied Biosystems) para 6ng de amostra em um volume final de $25 \mu \mathrm{L}$, ou com uso de ensaios TaqMan® probe (Applied Biosystems) (Tabela 2) para 40 ng de amostra em um volume final $20 \mu \mathrm{L}$ de ensaio.

Brevemente, o cDNA foi amplificado sob as seguintes condições de temperatura e tempo: a) para as reações utilizando Power SYBR® Green: $95{ }^{\circ} \mathrm{C}$ por $10 \mathrm{~min}, 40$ ciclos de 95 ${ }^{\circ} \mathrm{C}$ por $15 \mathrm{~s}$, seguidos por $60{ }^{\circ} \mathrm{C}$ por $1 \mathrm{~min}$, seguido da curva de dissociação $\left(95^{\circ} \mathrm{C}\right.$ por $15 \mathrm{~s}$ seguido de $60{ }^{\circ} \mathrm{C}$ por 1 min e $95^{\circ} \mathrm{C}$ por $15 \mathrm{~s}$ ); b) para ensaios TaqMan®: $50{ }^{\circ} \mathrm{C}$ por 2 min, 95 ${ }^{\circ}$ por $10 \mathrm{~min}, 40$ ciclos de $95{ }^{\circ} \mathrm{C}$ por $15 \mathrm{~s}$, seguidos por $60{ }^{\circ} \mathrm{C}$ por $1 \mathrm{~min}$. A fluorescência emitida pelo anelamento das amostras aos iniciadores foi medida em comprimento de onda de $470 \mathrm{~nm}$, e as quantidades relativas foram calculadas utilizando o método do $2^{-\Delta \Delta \mathrm{Ct}} 105$.

As concentrações de oligonucleotídeos iniciadores (para os ensaios com Power SYBR ${ }^{\circledR}$ Green) e os ensaios TaqMan® utilizados nas análises de expressão gênica estão especificados nas Tabelas 1 e 2, respectivamente.

Tabela 1 - Sequência de oligonucleotídeos iniciadores utilizados nos ensaios com Power SYBR® Green.

\begin{tabular}{cccc} 
Gene/proteína* & Sense & Anti-sense & $\begin{array}{c}\text { Concentração de } \\
\text { oligonucleotídeos }\end{array}$ \\
\hline Gapdh/GAPDH & AGTGCCAGCCTCGTCTCATAG & TAACCAGGCGTCCGATACG & $100 \mathrm{nM}$ \\
Sgk1/SGK1 & TATGGCCTGCCTCCGTTCT & GTGCCTTGCTGAGTTGGTGAT & $150 \mathrm{nM}$ \\
Bhlhals/Mist & GAACTTGTGCTTGGTCCATCCT & TCCCTATCCTGCGTTCACAAC & $150 \mathrm{nM}$ \\
& & & \\
\hline
\end{tabular}

* a proteína codificada está indicada para facilitar a interpretação dos resultados

Fonte: Zulian (2016). 
Tabela 2 - Ensaios TaqMan® usados para análises de expressão gênica.

\begin{tabular}{lll}
\hline Gene & ID do ensaio & Proteína codificada \\
\hline Actb & Rn00667869_m1 & $\beta$-actina \\
Nr3c1 & Rn00561369_m1 & Receptor de glicocorticoides \\
Muc6 & Rn1759814_m1 & Mucina 6 \\
Muc5ac & Rn01451270_g1 & Mucina 5AC \\
Fut1 & Rn00579894_m1 & $\alpha$-1,2-fucosil-transferase \\
Msn & Rn00675568_m1 & Moesina \\
Gif & Rn00567702_m1 & Fator intrínseco gástrico \\
$\boldsymbol{P g a 5}$ & Rn00572739_m1 & Pepsinogênio 5, grupo 1 \\
$\boldsymbol{P g} \boldsymbol{c}$ & Rn00590984_m1 & Pepsinogênio C \\
& & \\
\hline
\end{tabular}

Fonte: Zulian (2016).

\subsection{Histoquímica para detecção de glicoproteínas}

\subsection{1 Ácido periódico Reativo de Schiff e Alcian Blue (PASAB)}

Cortes não-seriados de $6 \mu \mathrm{m}$ da mucosa gástrica foram colocados em lâminas, desparafinizados, e então mantidos em ácido periódico (10 min). Após lavagem em água corrente, as lâminas foram imersas em Reativo de Schiff (30 min) e novamente lavadas. Depois de permanecerem em Alcian Blue (AB) (45 min), os cortes foram lavados, corados com Hematoxilina de Harris e montados em Goma de Damar.

As CMC foram identificadas pela reação com AB. Realizamos a quantificação sob microscópio de luz (Nikon, Japão) com o uso de uma ocular integradora com retículo (8 X, tipo Kpl2, Zeiss, Alemanha) e objetiva de imersão (100X). Esse retículo foi cuidadosamente deslocado em direção à base da glândula para observação de toda sua extensão. Utilizamos um total de 10 a 15 campos por animal e os resultados foram expressos em número de células reagentes para $\mathrm{AB}$ por campo/animal.

\subsubsection{Lectina Griffonia simplicifolia II (GSII)}


Cortes não-seriados de $6 \mu \mathrm{m}$ foram colocados em lâminas cobertas com poli-L-lisina (Sigma), desparafinizados, e então hidratados e permeabilizados com solução salina tamponada com fosfato (PBS) + Triton 0,3\% (PBS-Triton) (10 min). Em seguida, adicionamos lectina GSII conjugada a isotiocianato de fluoresceína (FITC, Vector, Burlingame, CA, EUA) $20 \mu \mathrm{g} / \mathrm{mL}$ (4 horas, TA). Após duas lavagens (5 min cada) com PBS 0,05 M, os cortes foram incubados com RNAse A (10 min, $5 \mathrm{mg} / \mathrm{mL}$, Calbiochem, San Diego, CA, EUA) e em seguida com brometo de etídio ( $3 \mathrm{~min}, 10 \mu \mathrm{g} / \mathrm{mL}$, Invitrogen) para identificação dos núcleos. Finalmente, as lâminas foram montadas em Mowiol (Calbiochem) e observadas em microscópio de fluorescência (Axioscope 2, software Zen, Zeiss, Alemanha).

A quantificação de células mucosas do colo ocorreu com o auxílio de uma marcação na ocular do microscópio que delimita uma área retangular. O número de células identificadas pela lectina GSII-FITC por campo foi contado sob objetiva de $40 \mathrm{X}$. Como esta lectina evidencia não somente as células mucosas do colo, mas também os precursores das células zimogênicas $(\mathrm{CZ})$ na base da glândula de animais em desenvolvimento ${ }^{15}$, foram anotadas somente as células reagentes localizadas no terço médio da glândula gástrica. Utilizamos um total de 5 a 10 campos por animal e os resultados também foram expressos em número de células marcadas por campo/animal.

\subsection{Imuno-histoquímica e quantificação das células imunomarcadas}

\subsubsection{Mucina 6}

Cortes não-seriados de $6 \mu \mathrm{m}$ foram desparafinizados e hidratados em PBS 0,05M pH 7,4 por 10 min. A peroxidase endógena foi inativada com solução de metanol (Merck) e $\mathrm{H}_{2} \mathrm{O}_{2}$ 3\% (10 min, Merck) e, após lavagens em água e PBS, seguiu-se a etapa de recuperação antigênica com proteinase $\mathrm{K}(20 \mu \mathrm{g} / \mathrm{mL}, 1 \mathrm{~h}$ a TA) (Gibco, Carlsberg, CA, EUA). Os cortes foram incubados com anticorpo policlonal de coelho contra mucina $6\left(8 \mu \mathrm{g} / \mathrm{mL}\right.$, overnight, $4^{\circ}$ C, Santa Cruz Biotechnology, Santa Cruz, CA, EUA). Após lavagem com PBS, os cortes foram expostos ao anticorpo secundário de cabra anti-coelho conjugado com biotina $(5,5$ $\mu \mathrm{g} / \mathrm{mL}, 2 \mathrm{~h}$ a TA) (Jackson ImmunoResearch Laboratories, PA, EUA) seguido de complexo estreptavidina-peroxidase $(5 \mu \mathrm{g} / \mathrm{mL}, 2$ h,a TA). A revelação foi realizada com o sistema de substrato-cromógeno 3,3'-diaminobenzidina (DAB), Liquid DAB+ e $\mathrm{H}_{2} \mathrm{O}_{2}$ (Dako, Carpinteria, CA, EUA), seguida de contracoloração com Hematoxilina de Mayer $0,1 \%$ e 
diferenciação em solução saturada de carbonato de lítio. O controle negativo foi obtido pela omissão do anticorpo primário.

A quantificação das células positivas para mucina 6 ocorreu sob microscópio de luz, após a observação das lâminas com o uso de uma ocular integradora com retículo ( 8 X, Kpl2, Zeiss) e objetiva de imersão $(100 \mathrm{X})$. Foram quantificadas as células marcadas e nãomarcadas, em um total de 1.000 células observadas em secções bem orientadas das regiões de colo e início da base da glândula gástrica. O resultado foi analisado como número de células marcadas/total de células epiteliais observadas X 100, e expresso como índice de marcação $(\%) /$ animal.

\subsubsection{Mist1}

Cortes não-seriados de $6 \mu \mathrm{m}$ foram desparafinizados e hidratados em PBS 0,05 M pH 7,4 (10 min). Em seguida, as lâminas passaram por um pré-tratamento com Tris- $\mathrm{HCl}$ 0,05 M pH 9,0 (5 min, 600 watts e 10 min, 300 watts) em microondas para resgate de antígeno. Após o resfriamento, e lavagem com PBS, os cortes foram incubados com o anticorpo monoclonal de camundongo para Mist1 ( $8 \mu \mathrm{g} / \mathrm{mL}$, overnight, $4{ }^{\circ} \mathrm{C}$ ) (Santa Cruz Biotechnology). Após outra lavagem com PBS, os cortes foram incubados com o anticorpo secundário de burro anticamundongo conjugado com Cy3 (26 $\mu \mathrm{g} / \mathrm{mL}$ em PBS, 2 h) (Jackson ImmunoResearch Laboratories). Após duas lavagens (5 min cada) com PBS 0,05 M, as lâminas foram montadas em Mowiol (Calbiochem). O controle negativo da reação foi obtido pela omissão do anticorpo primário. Para aquisição de imagens representativas dos resultados, as lâminas foram submetidas à mesma técnica descrita acima e montadas com Mowiol (Calbiochem) acrescido de 4',6-diamidino-2-fenilindol (DAPI, 0,5 $\mu \mathrm{g} / \mathrm{mL}$ Invitrogen).

A quantificação dos núcleos imuno-marcados ocorreu sob microscópio de fluorescência (Zeiss), como descrito acima para GSII-FITC. Assim, com o auxílio de uma marcação na ocular do microscópio que delimita uma área retangular e objetiva de imersão (100 X), contamos um total de 10 a 15 campos por animal. Os resultados foram expressos em número de células imuno-marcadas por campo/animal.

\subsubsection{Pepsinogênio C $(P G C)$}


Cortes não-seriados de $3 \mu \mathrm{m}$ foram desparafinizados e hidratados em PBS $0,05 \mathrm{M} \mathrm{pH}$ 7,4 por 10 min. A peroxidase endógena foi inativada com metanol- $\mathrm{H}_{2} \mathrm{O}_{2} 3 \%$ (10 min) e, após lavagens em água e PBS, os cortes foram incubados com anticorpo de cabra contra PGC (2 $\mu \mathrm{g} / \mathrm{mL}$, overnight, $4{ }^{\circ} \mathrm{C}$ ) (Santa Cruz Biotechnology). Após outra lavagem com PBS, os cortes foram incubados com anticorpo secundário de coelho anti-cabra conjugado com peroxidase (3,2 $\mu \mathrm{g} / \mathrm{mL}, 2$ h, TA) (Jackson ImmunoResearch Laboratories).

A revelação foi realizada com o sistema de substrato-cromógeno 3,3'diaminobenzidina (DAB), Liquid DAB+ e $\mathrm{H}_{2} \mathrm{O}_{2}$ (Dako), seguida de contracoloração com Hematoxilina de Mayer $0,1 \%$ e diferenciação em solução saturada de carbonato de lítio. $\mathrm{O}$ controle negativo foi obtido pela omissão do anticorpo primário.

A quantificação de CZ imuno-positivas foi realizada considerando-se a morfologia da célula e a presença de reação positiva no citoplasma. Utilizamos microscópio de luz com ocular integradora com retículo ( 8 X, tipo Kpl2, Zeiss) e objetiva de imersão (100 X). Foram quantificadas as células marcadas e não- marcadas, em um total de 1.000 células observadas em secções bem orientadas da base da glândula gástrica. O resultado foi analisado como número de $\mathrm{CZ}$ marcadas/total de células epiteliais observadas X 100, e expresso como índice de marcação (\%)/animal.

\subsection{Registro de imagens}

As reações estudadas sob microscópio de luz (Nikon, Japão) foram registradas com o uso do software Image ProPlus v.5.2 (Media Cybernetics, Bethesda, USA) em microscópio de luz (Olympus, Montreal, Canada). As reações avaliadas em microscopia de fluorescência (Axioscope 2, Zeiss) foram registradas e as imagens capturadas com o software Zen 22011 (edição azul, Zeiss). Para as reações com lectina GSII, as fotomicrografias foram obtidas no mesmo microscópio utilizado para as análises, já para as reações de imuno-histoquímica para Mist1, as imagens foram capturadas no microscópio confocal de varredura a laser (LSM 780NLO, Zeiss) com o auxílio do software ZEN (2010B SP1, Zeiss) (CEFAP-ICB/USP, São Paulo, Brasil).

\subsection{Análise estatística}


Os resultados foram agrupados de acordo com o tratamento e expressos como média \pm desvio padrão. Para avaliar a interação entre padrão alimentar (dieta) e ação da corticosterna (por meio do antagonista RU486) utilizamos ANOVA a dois critérios. Para analisar os resultados obtidos para os diferentes grupos em uma mesma idade, usamos ANOVA seguida de teste de Tukey ou teste $t$ de Student, dependendo da comparação necessária. Os resultados foram considerados significativos quando $\mathrm{p}<0,05$. 


\section{RESULTADOS}

\subsection{Massa corpórea dos animais}

A massa corpórea dos animais foi monitorada ao longo de todos os experimentos, visto que a mudança do padrão alimentar pode induzir um retardo no ganho de massa dos filhotes $46 ; 48 ; 106$.

Os animais dos grupos amamentados (A e ARU) apresentaram variação positiva da massa corpórea ao longo do período experimental, embora as diferenças, quando comparadas diariamente, não sejam significativas (Figura 5). Já os animais desmamados precocemente (DP e DPRU) apresentaram redução na massa corpórea aos 17 dias de vida pós-natal ( $\mathrm{p}<0,01)$ que se manteve até o $19^{\circ}$ dia. Do $20^{\circ}$ ao $27^{\circ}$ dia de experimentação, todos os grupos ganharam peso de forma semelhante, independente do tratamento. Entretanto, no $28^{\circ}$ dia, pudemos observar, novamente, menor massa corpórea nos animais dos grupos DP e DPRU ( $<<0,05)$, sendo este resultado mantido até o final das análises. 


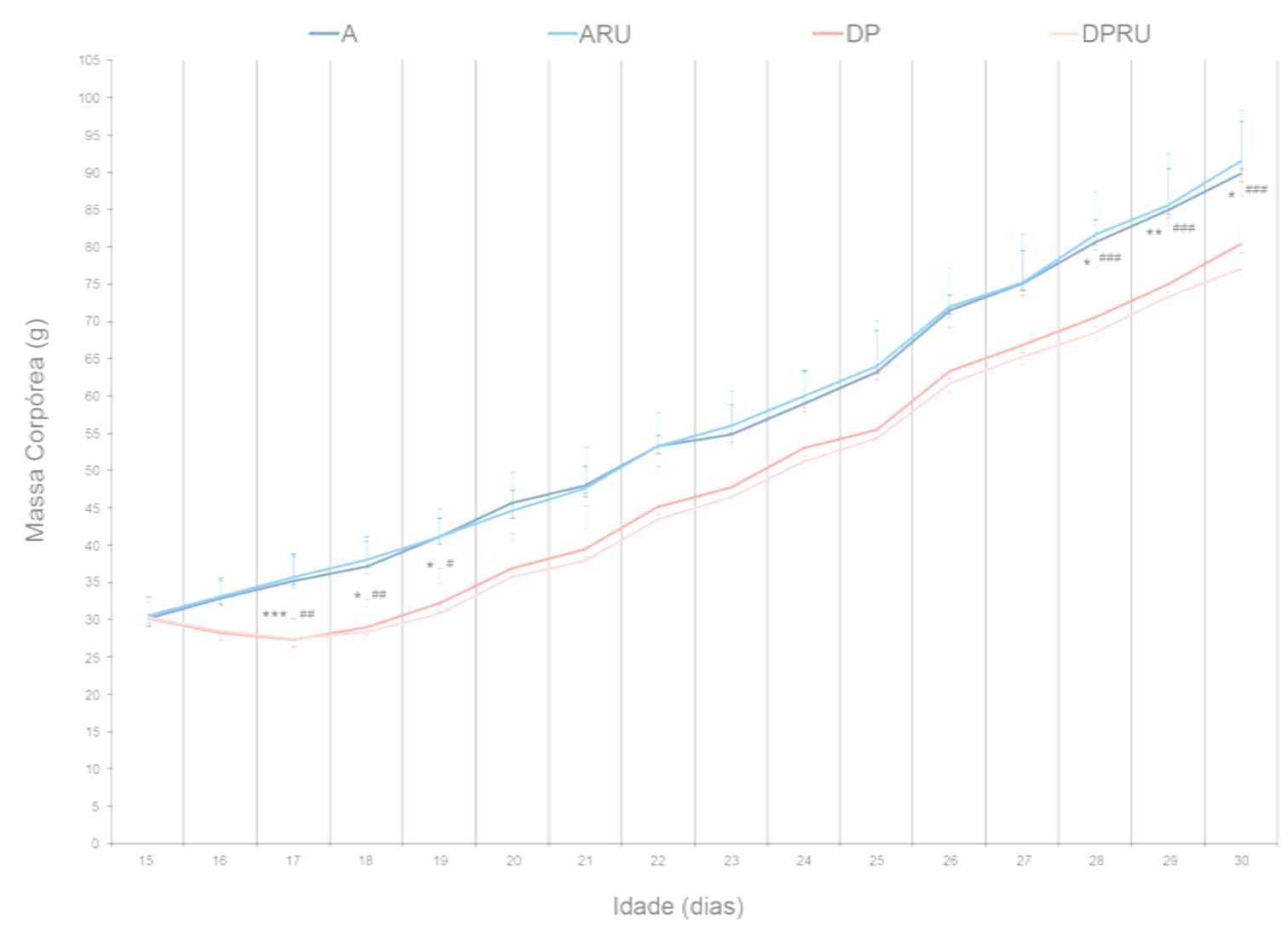

Figura 5 - Massa corpórea de ratos ao longo do período experimental (do $15^{\circ}$ ao $30^{\circ}$ dia) submetidos ou não ao desmame precoce e/ou tratados com RU486 ou veículo. Cada ponto representa média \pm desvio padrão. Foram considerados todos os animais utilizados nos diversos experimentos ( $\mathrm{n}=7-27$ animais/grupo/idade). Os resultados foram analisados por ANOVA seguido de teste de Tukey e observamos em relação ao grupo A da mesma idade: ${ }^{*} \mathrm{p}<0,05 ; * * \mathrm{p}<0,01 \mathrm{e} * * * \mathrm{p}<0,0001$; em relação ao grupo ARU de mesma idade: $\# \mathrm{p}<0,05$; $\# \# \mathrm{p}<0,01$ e \#\#\#p<0,0001.

Além do acompanhamento diário, os animais também foram pesados no momento da coleta de amostras e as médias de massa corpórea aos 17, 18 e 30 dias (pontos de estudo) estão apresentadas na Tabela 3.

Tabela 3 - Massa corpórea (g) dos animais por grupo de estudo no momento da eutanásia.

\begin{tabular}{lllll}
\hline Idade (dias) & A & ARU & DP & DPRU \\
\hline 17 & $34,55 \pm 3,88$ & $34,03 \pm 4,26$ & $27,99 \pm 2,70^{* * *}$ & $27,71 \pm 3,31 \# \# \#$ \\
18 & $36,75 \pm 4,79$ & $36,00 \pm 5,21$ & $28,87 \pm 3,27 * *$ & $29,62 \pm 4,53 \# \# \#$ \\
30 & $90,00 \pm 8,96$ & $92,08 \pm 5,20$ & $80,89 \pm 9,79 *$ & $76,35 \pm 3,85 \# \# \#$ \\
\hline
\end{tabular}

Os resultados foram analisados por teste $t$ de Student e observamos em relação ao grupo A da mesma idade: ${ }^{*} \mathrm{p}<0,05 ; * * \mathrm{p}<0,01 \mathrm{e} * * * \mathrm{p}<0,0001$; em relação ao grupo ARU de mesma idade: \#\#\# $<0,0001$.

Fonte: Zulian (2016). 


\subsection{Avaliação de genes ligados à diferenciação do epitélio gástrico e à ação da corticosterona}

Reações de PCR quantitativo foram conduzidas para avaliarmos a expressão de genes marcadores da maturação e das funções da glândula gástrica em animais amamentados ou submetidos ao desmame precoce, e tratados ou não com RU486.

Ao analisarmos como o DP influencia a expressão de genes relacionados à maturação do epitélio gástrico, observamos que, em filhotes de 17 dias, os genes Muc5ac (célula mucosa superficial), Muc6 (célula mucosa do colo) (Figura 7), Bhlhal5 (célula zimogênica em diferenciação) e $P g c$ (célula zimogênica madura) (Figura 6) tiveram expressão aumentada, quando comparados aos grupos amamentados (A e ARU) (p<0,05) (Figuras 6 e 7), enquanto os níveis de Gif e Msn (ambos marcadores de célula zimogênica) foram reduzidos quando comparamos ARU e DPRU (p<0,05) (Figura 6). Já o gene Pga5, que codifica um tipo imaturo de pepsinogênio, teve sua expressão reduzida em filhotes submetidos ao desmame precoce, independente da ação do antagonista $(\mathrm{p}<0,05)$ (Figura 6).

Em ratos de 30 dias, apenas a resposta de $P g c$ foi mantida, ou seja, o grupo DP apresentou expressão significativamente mais alta desse gene quando comparado ao grupo A $(\mathrm{p}<0,05)$ (Figura 6). Para o pepsinogênio imaturo (Pga5), o desmame precoce provocou redução na expressão gênica (comparados os grupos ARU e DPRU) (p<0,05), enquanto que para o gene $M s n$, observamos redução de expressão em relação ao grupo A $(\mathrm{p}<0,05)$ e aumento de expressão em relação ao ARU $(\mathrm{p}<0,05)$ quando analisamos os efeitos do DP em ratos adultos-jovens. Todos os resultados estão resumidos na Tabela 3.

Já é sabido que o DP promove a elevação da corticosterona plasmática durante o início do tratamento ${ }^{46 ; 53} \mathrm{e}$, para avaliar o papel deste hormônio na mucosa gástrica, reduzimos sua atividade por meio do bloqueio de GR com a administração de RU486. Como mencionado anteriormente, a eficácia deste tratamento pode ser atestada pela expressão de $S g k l$.

Observamos que, em animais de 17 dias, o RNAm desta quinase serina/treonina foi aumentado pelo DP $(\mathrm{p}<0,05)$ (Figura 7) e o tratamento com RU486 reduziu significativamente sua expressão $(\mathrm{p}<0,01)$, comprovando a eficiência do tratamento e a relação entre a resposta ao fármaco e o padrão alimentar $(\mathrm{p}<0,01)$. Em ratos de 30 dias, não observamos variações significativas. O RNAm que codifica o GR (Nr3cl) também foi avaliado e os resultados mostraram que os tratamentos utilizados não mudaram os níveis de expressão gênica nas duas idades testadas (Figura 7). 
Em relação aos genes marcadores da maturação da mucosa gástrica, $M u c 5 a c$ e $P g c$, o bloqueio da corticosterona reduziu a expressão dos mesmos em ratos de 17 dias desmamados precocemente $(\mathrm{p}<0,05)$. Quando ANOVA a dois critérios foi utilizada para testar os efeitos sobre esses genes, observamos interação significativa, ou seja, o efeito da corticosterona foi dependente da dieta. Ainda em filhotes, para o RNAm da mucina 6, o antagonista aumentou a expressão gênica, quando os grupos A e ARU foram comparados e não causou efeito no grupo DP $(\mathrm{p}<0,01)$ (Figura 7).

Já em ratos de 30 dias submetidos ao DP, o bloqueio da corticosterona diminuiu a expressão do gene Pga5 (p<0,05) e manteve a resposta (já observada em filhotes) para o gene do pepsinogênio C. Ou seja, o tratamento com RU486 reduziu a expressão de $P g c$ em adultosjovens que passaram pelo DP $(\mathrm{p}<0,01)$ (Figura 6). Esse resultado novamente a interação entre a dieta e a resposta à corticosterona (ANOVA a dois critérios, $\mathrm{p}<0,05$ ).

Pudemos constatar também que, em ratos de 30 dias, o gene codificador da moesina (Msn) apresentou uma redução no RNAm do grupo ARU em relação ao grupo A $(\mathrm{p}<0,05)$, e um aumento significativo para os animais DPRU comparados aos DP ( $\mathrm{p}<0,05)$ (Figura 6). Esses efeitos contrários mostram que a expressão deste gene pode ser controlada diferentemente pela corticosterona (resposta ao RU486) de acordo com o padrão alimentar $(\mathrm{p}<0,01)$. 

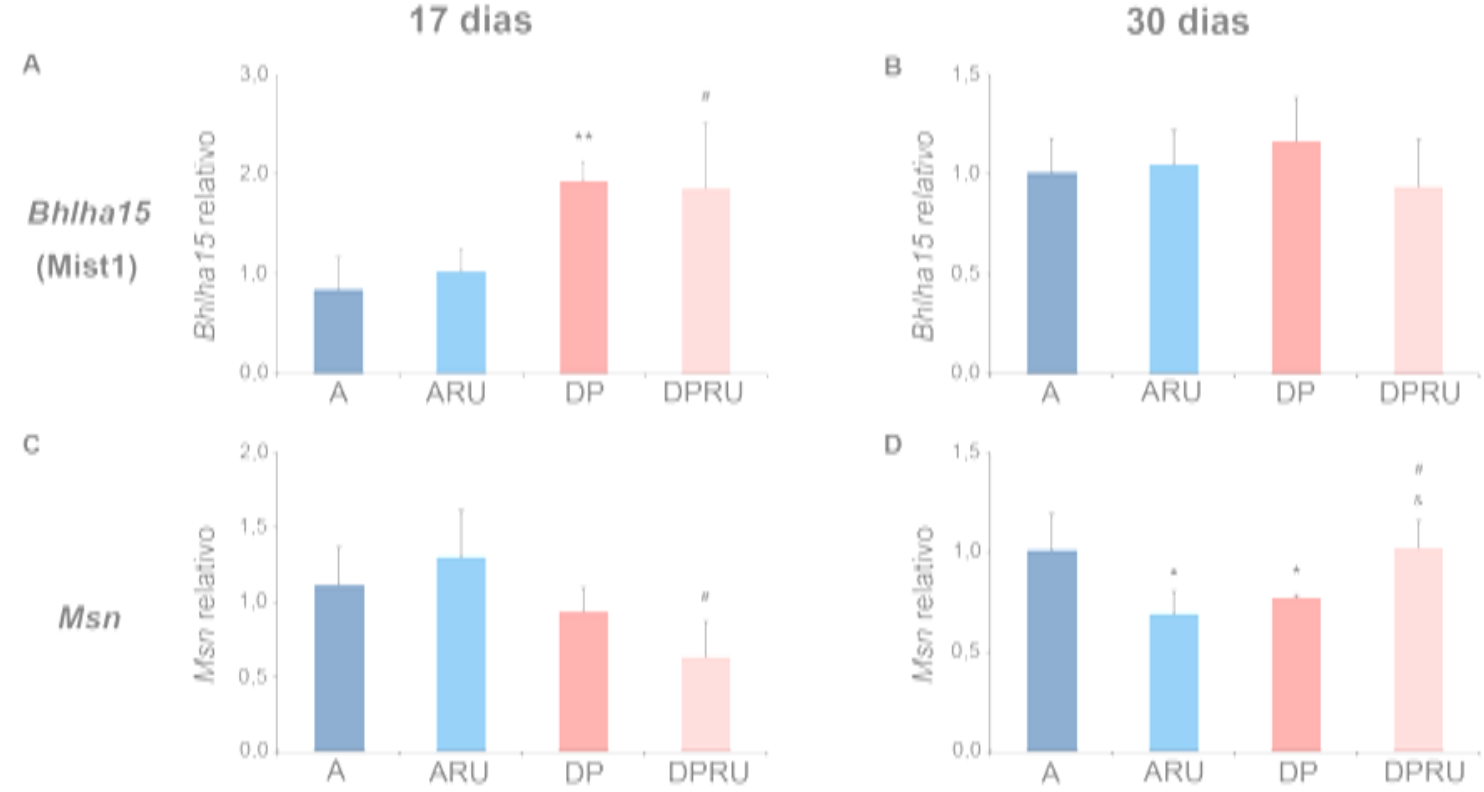

E
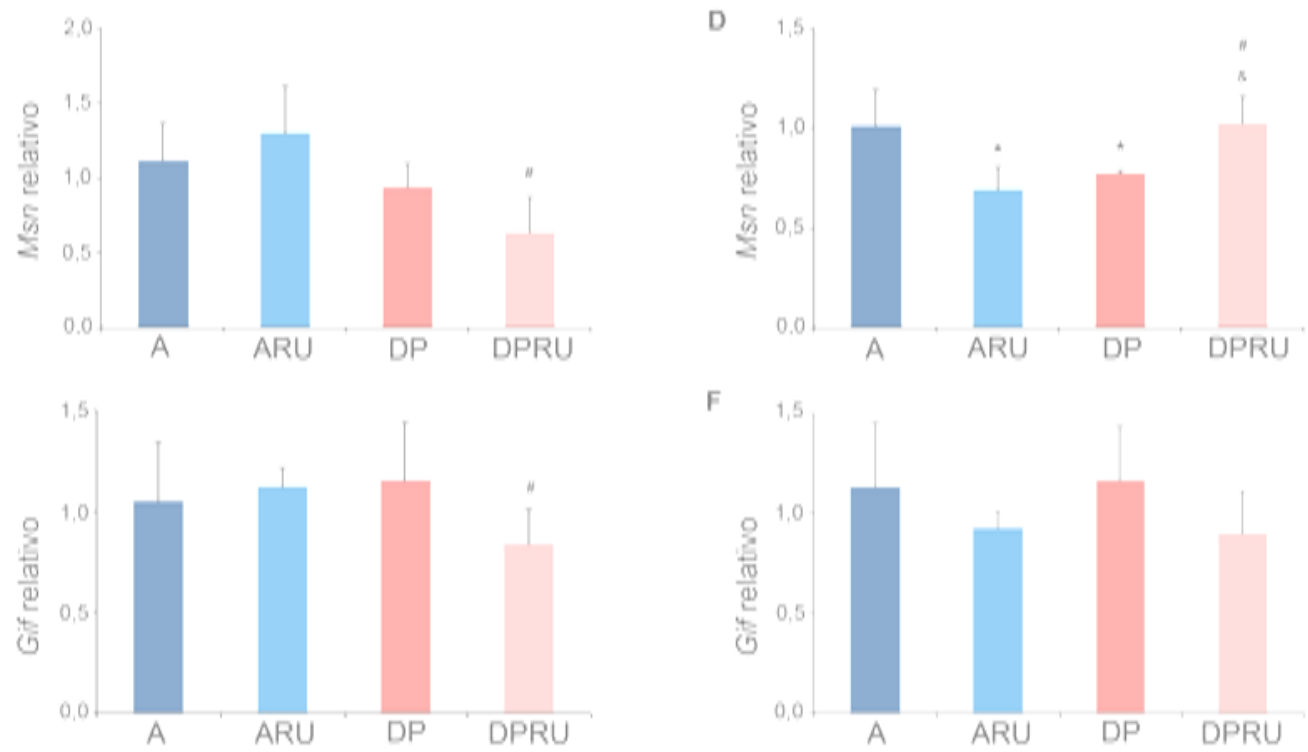

G
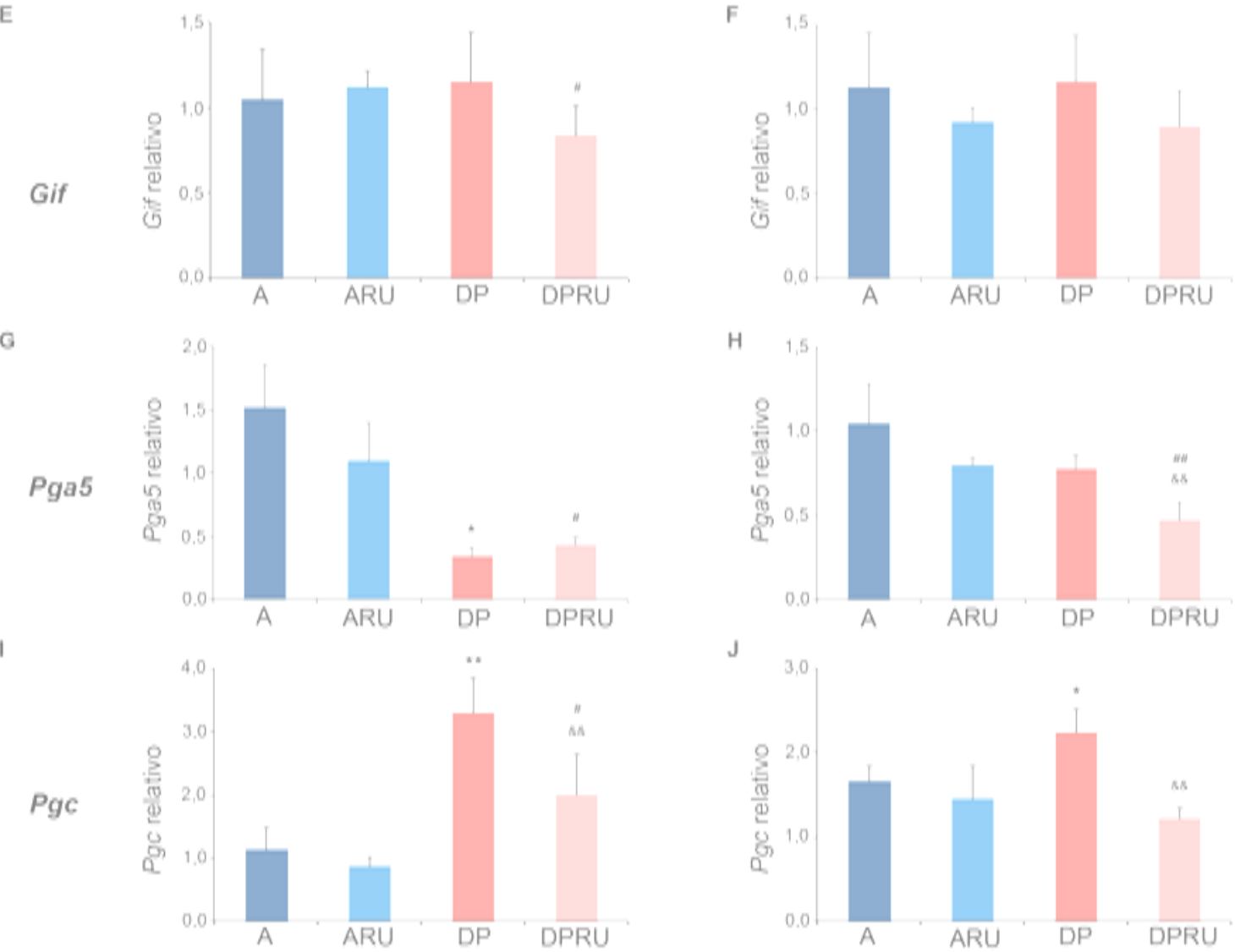

Figura 6 - Expressão de genes do epitélio gástrico de ratos submetidos ou não ao desmame precoce e/ou tratados com RU486 ou veículo. RT-PCRq para Bhlha15 (A e B), Msn (C e D), Gif (E e F), $P g a 5(\mathrm{G} \mathrm{e} \mathrm{H})$ e $P g c$ (I e J) em animais de 17 (A, C, E, G e I) e 30 dias (B, D, F, H e J). A quantidade relativa foi calculada considerando o grupo A como referência e cada barra representa média \pm desvio padrão. $(\mathrm{n})=3-5$ animais por grupo por idade para cada gene. Em relação ao grupo $A$ : ${ }^{*} \mathrm{p}<0,05 ; * * \mathrm{p}<0,01$; em relação ao grupo ARU: $\# \mathrm{p}<0,05$; \#\#p<0,01; em relação ao grupo DP: \&p<0,05; \&\&p<0,01. 
17 dias

A

Nr3c1

(GR)

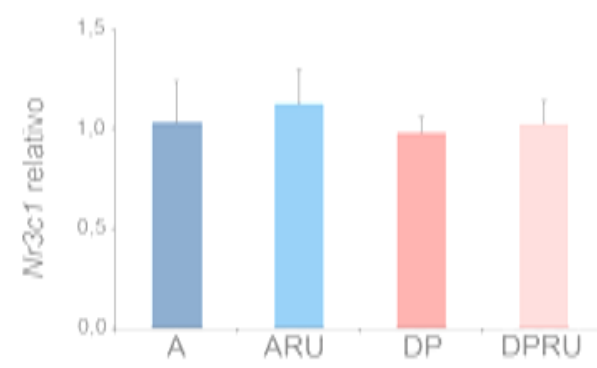

C

Sgk1

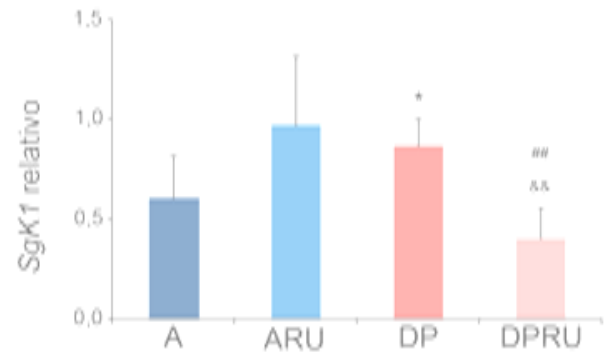

E

Muc5ac

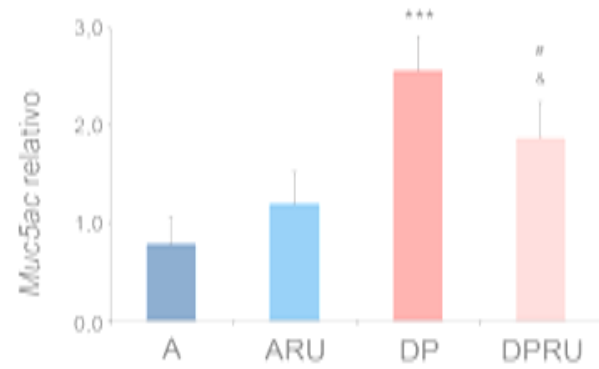

G

Muc6

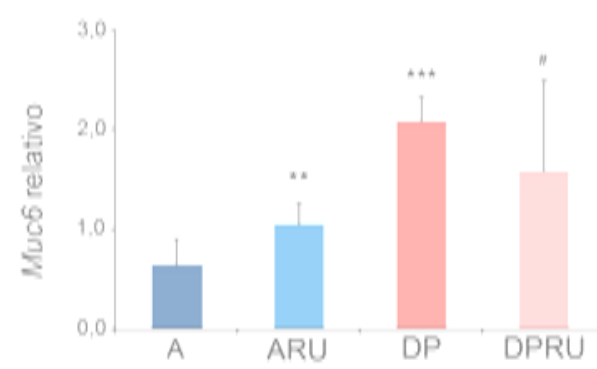

I

Fut1

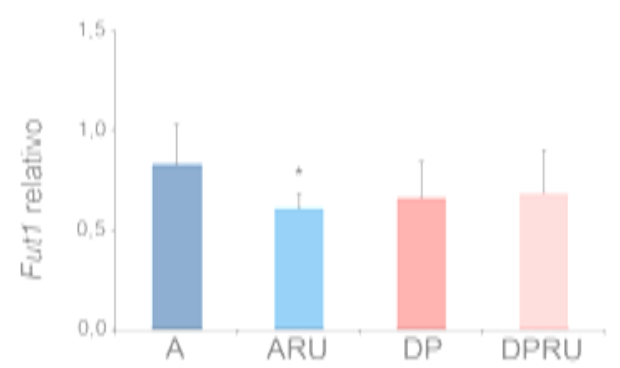

30 dias
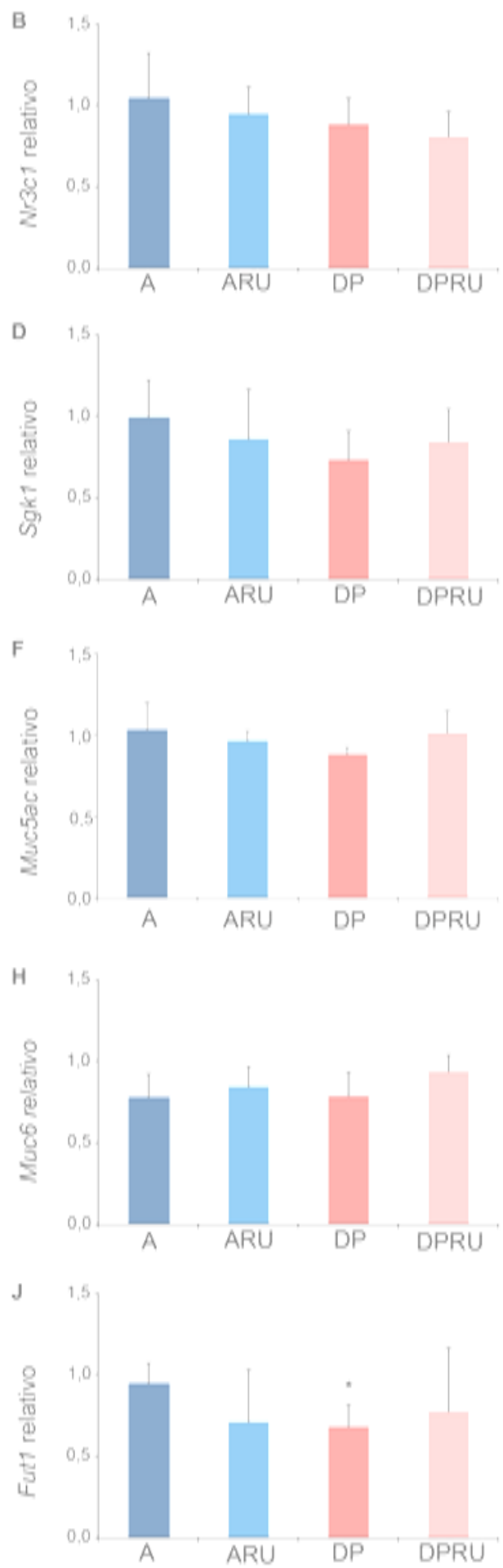

Figura 7 - Expressão de genes do epitélio gástrico de ratos submetidos ou não ao desmame precoce e/ou tratados com RU486 ou veículo. RT-PCRq para $N r 3 c l(\mathrm{~A}$ e B), $S g k l(\mathrm{C}$ e D), Muc5ac (E e F), Muc6 (G e H) e Fut1 (I e J) em animais de 17 (A, C, E, G e I) e 30 dias (B, D, F, H e J). A quantidade relativa foi calculada considerando o grupo A como referência e cada barra representa média \pm desvio padrão. $(n)=3-5$ animais por grupo por idade para cada gene. Em relação ao grupo A: ${ }^{*} \mathrm{p}<0,05 ; * * \mathrm{p}<0,01$ e $* * * \mathrm{p}<0,0001$; em relação ao grupo ARU: \#p<0,05; \#\#p<0,01; em relação ao grupo DP: \&p<0,05; \&\&p<0,01. 
A mucosa gástrica é recoberta pelo muco produzido pelas células mucosas superficiais (CMS) e células mucosas do colo (CMC) ${ }^{107 ;} 108$, sendo as mucinas, glicoproteínas de alto peso molecular ${ }^{18 ; 109}$ um dos principais componentes deste muco ${ }^{110}$. Para avaliar se o DP e a corticosterona poderiam alterar elementos responsáveis pela glicosilação da mucina 6 , o gene Fut1 também foi estudado por PCRq. Fut1 codifica a enzima de glicosilação $\alpha$-1,2-fucosiltransferase ${ }^{111}$ e é encontrado apenas na porção glandular da mucosa gástrica, não sendo expresso na fosseta ${ }^{112}$. Nossos resultados mostraram que o DP não alterou sua expressão aos 17 dias, porém quando este grupo foi estudado aos 30 dias, notamos uma redução do nível de Fut1 (p<0,05) (Figura 7). Já o tratamento com o antagonista influenciou a expressão desse gene somente na mucosa gástrica de filhotes amamentados (ARU), reduzindo o RNAm em relação ao grupo controle $(\mathrm{A})(\mathrm{p}<0,05)$.

A Tabela 4 resume os resultados obtidos pela técnica de RT-PCRq nos grupos avaliados para comparação do efeito do desmame precoce com amamentação, e do efeito da administração de RU486 de acordo com o padrão alimentar.

Tabela 4 - Resumo dos resultados obtidos pela técnica de RT-PCRq mostrando os efeitos do DP e do bloqueio da ação da corticosterona com RU486 para os grupos do estudo.

\begin{tabular}{|c|c|c|c|c|c|c|c|c|c|c|}
\hline \multirow[b]{2}{*}{ Gene } & Idade & \multicolumn{2}{|c|}{17 dias } & \multicolumn{2}{|c|}{30 dias } & Idade & \multicolumn{2}{|c|}{$\begin{array}{c}17 \\
\text { dias }\end{array}$} & \multicolumn{2}{|c|}{$\begin{array}{c}\text { 30 } \\
\text { dias }\end{array}$} \\
\hline & $\begin{array}{c}\text { Tratamento(condição } \\
\text { alimentar) }\end{array}$ & $\mathbf{A}$ & ARU & & ARU & $\begin{array}{c}\text { Tratamento } \\
\text { (bloqueio } \\
\text { CORT) }\end{array}$ & $\mathbf{A}$ & DP & $\mathbf{A}$ & DP \\
\hline Bhlha15 & \multirow{10}{*}{ DP/DPRU } & $\uparrow$ & $\uparrow$ & - & - & \multirow{10}{*}{ RU486 } & - & - & - & - \\
\hline$M s n$ & & - & $\downarrow$ & $\downarrow$ & $\uparrow$ & & - & - & $\downarrow$ & $\uparrow$ \\
\hline Gif & & - & - & - & - & & - & $\downarrow$ & - & - \\
\hline Pga5 & & $\downarrow$ & $\downarrow$ & - & $\downarrow$ & & - & - & - & $\downarrow$ \\
\hline$P g c$ & & $\uparrow$ & $\uparrow$ & $\uparrow$ & $\uparrow$ & & - & $\downarrow$ & - & $\downarrow$ \\
\hline $\mathrm{Nr} 3 \mathrm{cl}$ & & - & - & - & - & & - & - & - & - \\
\hline Sgk1 & & $\uparrow$ & $\downarrow$ & - & - & & - & $\downarrow$ & - & - \\
\hline Muc5ac & & $\uparrow$ & $\uparrow$ & - & - & & - & $\downarrow$ & - & - \\
\hline Мuc6 & & $\uparrow$ & $\uparrow$ & - & - & & $\uparrow$ & - & - & - \\
\hline Futl & & - & - & $\downarrow$ & - & & $\downarrow$ & - & - & - \\
\hline
\end{tabular}

Comparações relativas entre tratamento e respectivo controle: $\uparrow$ indica o aumento de expressão; $\downarrow$ indica diminuição de expressão; - indica ausência de resposta

\subsection{Avaliação da população de células mucosas do colo (CMC)}


Sabe-se que animais submetidos ao DP apresentam um aumento significativo na população de $\mathrm{CMC}$, a partir do $17^{\circ}$ dia de vida pós-natal, quando comparados a animais em amamentação ${ }^{49}$. Para verificar o efeito da corticosterona na aceleração da diferenciação dessas células na mucosa gástrica, utilizamos o antagonista da ação hormonal (RU486) e realizamos duas reações histoquímicas (PASAB e lectina GSII-FITC), que evidenciam o muco produzido pelas CMC, em animais de 17, 18 e 30 dias de vida pós-natal. Também avaliamos as $\mathrm{CMC}$ através da técnica de imuno-histoquímica para mucina 6 nos quatro grupos experimentais aos 18 e 30 dias.

Por meio da técnica de PASAB, observamos células mucosas superficiais coradas em azul escuro e púrpura, enquanto que as CMC aparecem em azul ciano na região média da glândula. O DP aumentou o número de células positivas no epitélio gástrico quando comparado com o grupo A aos 17 e 18 dias $(\mathrm{p}<0,01)$ (Figura 8), corroborando resultados anteriores ${ }^{49}$. Aumento este que foi de $150 \%$ quando comparamos os filhotes A e DP aos 17 dias, e de $90 \%$ aos 18 dias de idade. Observamos também a interação significativa entre o padrão alimentar e a ação da corticosterona (ANOVA a dois critérios), uma vez que o padrão alimentar (A ou DP) influenciou a resposta ao antagonista (RU486 não induziu alterações no grupo ARU, mas reduziu significativamente o número de células/campo em filhotes desmamados precocemente) $(\mathrm{p}<0,01)$ (Figura 8). Esse efeito foi mais proeminente em 17 dias $(\mathrm{p}<0,01)$. Assim, registramos uma diminuição de 45 e 30\%, aos 17 e 18 dias respectivamente após o tratamento com RU486. 

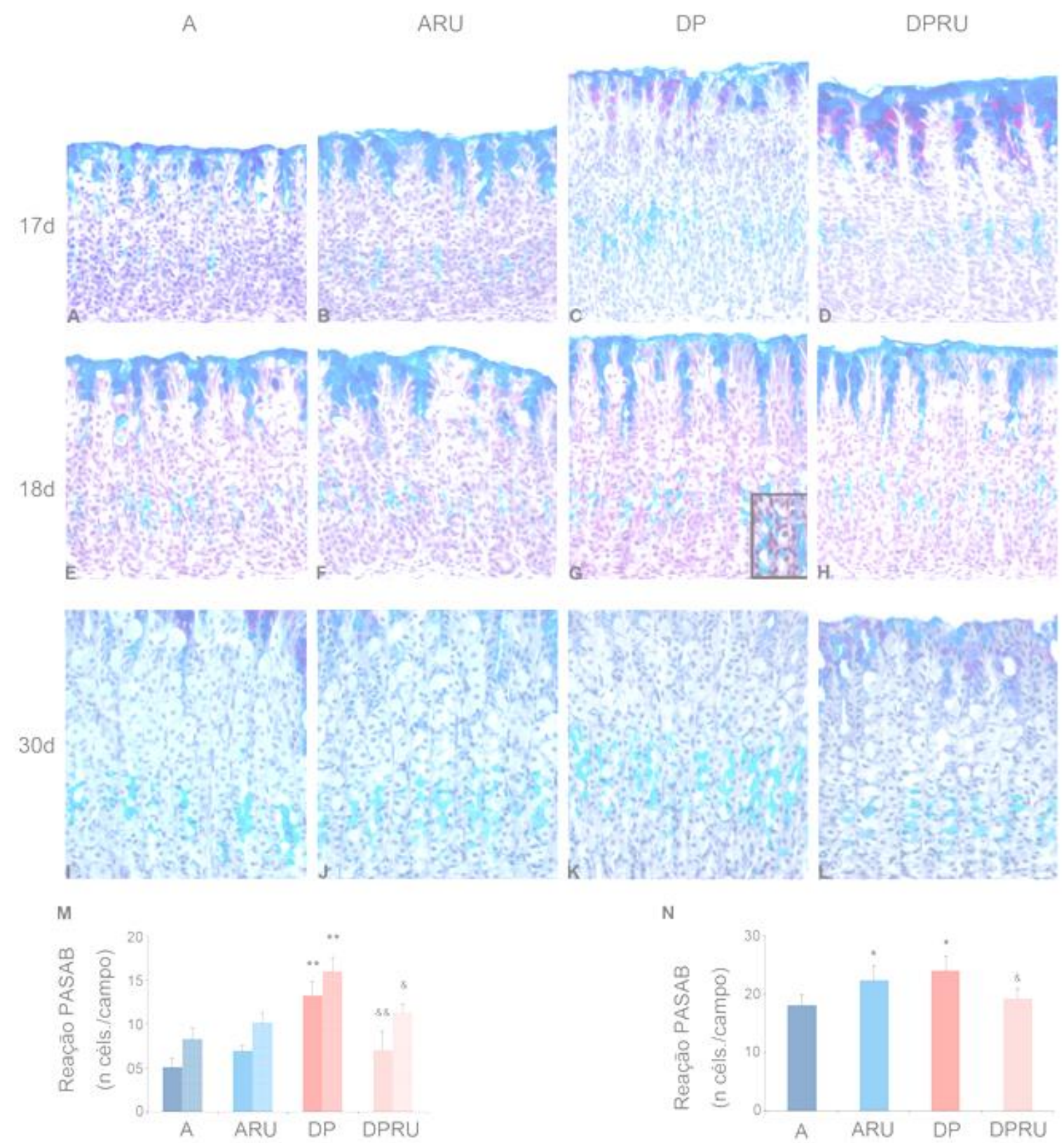

Figura 8 - Avaliação da distribuição das células mucosas do colo no epitélio gástrico de ratos submetidos ou não ao desmame precoce e/ou tratados com RU486 ou veículo. Fotomicrografias representativas de reações histoquímicas de PASAB em animais amamentados e injetados com veículo (A, E e I) ou RU486 (B, F e J) e animais submetidos ao desmame precoce e injetados com veículo (C, G e K) ou RU486 (D, H e L) aos 17 (AD), 18 (E-H) e 30 (I-L) dias de vida pós-natal. Aumentos originais: 40 x (A-L) e 100x (detalhe na figura C). Quantificação de células /campo positivas para PASAB em animais de 17 (barra da esquerda) 18 (barra da direita) (M) e 30 dias (N). Cada barra representa a média \pm desvio. $n$ de 3-4 animais por grupo por idade. Em relação ao grupo A: ${ }^{*} \mathrm{p}<0,05$ e $* * \mathrm{p}<0,01 ;$ em relação ao grupo DP: $\& \mathrm{p}<0,05 ; \& \& \mathrm{p}<0,01$.

A reação histoquímica com GSII-FITC foi utilizada para comparar e validar os resultados acima, e como este método evidencia CMC e células pré-zimogênicas, as células reagentes ficaram concentradas nas regiões de colo e início da base da glândula gástrica aos 
17 e 18 dias. Entretanto, como mencionado anteriormente, a fim de obter o número de CMC/campo, consideramos exclusivamente as células marcadas na região de colo da glândula. Conforme descrito ${ }^{49}$, aos 17 e 18 dias, o DP aumentou a população de células GSIIpositivas em mais de $45 \%$ quando comparado ao grupo A (p<0,01) (Figura 9). Além disso, como detectado pela reação PASAB, observou-se que o padrão alimentar (A ou DP) influenciou significativamente a resposta ao antagonista $(\mathrm{p}<0,0001)$, e verificamos que em filhotes desmamados precocemente, o tratamento com RU486 reduziu a população de células evidenciadas pela GSII-FITC em 30\% em 17 dias ( $<<0,01)$, e em 14\% aos 18 dias ( $<<0,05)$ (Figura 9).

A fim de avaliar se os efeitos do DP e da corticosterona sobre a maturação das CMC iriam persistir até a idade adulta, realizamos as mesmas reações histoquímicas em seções gástricas obtidas de animais de 30 dias. Por meio da técnica de PASAB, notamos que os efeitos induzidos pelo DP prevaleceram, de forma que a população de CMC nesse grupo é maior do que a observada no A $(\mathrm{p}<0,05)$ (Figura 8). Verificamos também que o RU486 diminuiu o número de CMC/campo durante o DP (DPRU) quando comparado ao respectivo controle $(\mathrm{p}<0,05)$, porém nessa idade, notamos também que o grupo ARU apresentou um maior número de células marcadas do que o grupo $\mathrm{A}(\mathrm{p}<0,05)$ (Figura 8$)$, resultado este que não havia sido detectado nos filhotes. Por meio da reação histoquímica com GSII-FITC, obtivemos resultados semelhantes, embora sem diferença significativa entre os grupos (Figura 9).

Cabe destacar que, quando comparamos amostras de 18 e de 30 dias de idade, constatamos que a população de CMC aumentou quase três vezes nos grupos amamentados. Comparativamente, quando os animais desmamados precocemente foram considerados, o aumento do número de CMC foi menos pronunciado (duas vezes menor), em virtude da amplificação precoce e anterior induzida pela mudança de dieta em filhotes de 18 dias $(\mathrm{p}<0,01)$. Pudemos observar também, que o padrão de distribuição das CMC na glândula gástrica não foi afetado pelo DP ou bloqueio da corticosterona em nenhuma das idades consideradas no estudo. 

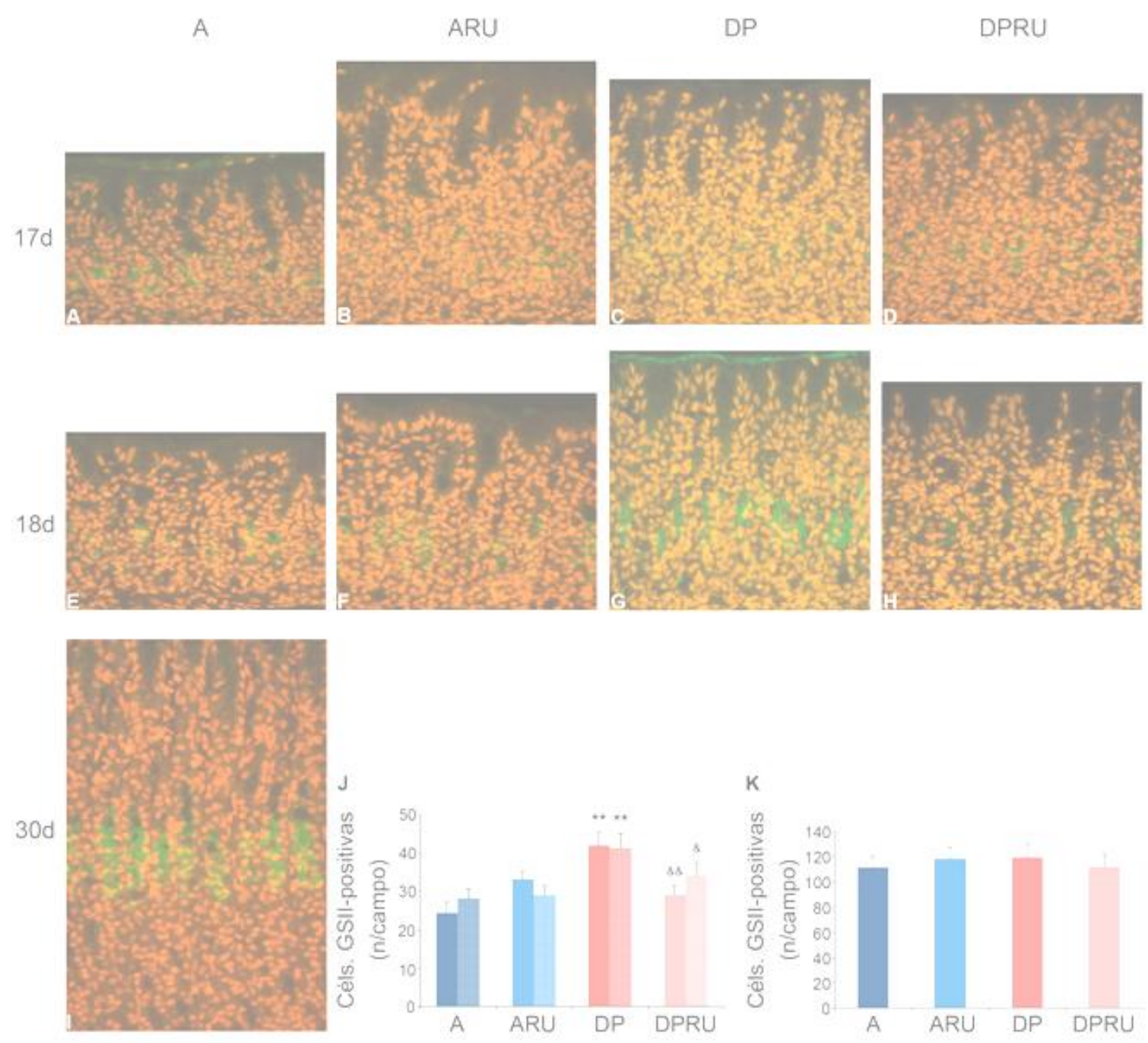

Figura 9 - Avaliação da distribuição das células mucosas do colo no epitélio gástrico de ratos submetidos ou não ao desmame precoce e/ou tratados com RU486 ou veículo. Fotomicrografias representativas de reações histoquímicas de lectina GSII-FITC em animais amamentados e injetados com veículo (A, E e I) ou RU486 (B e F) e animais submetidos ao desmame precoce e injetados com veículo (C e G) ou RU486 (D e H) aos 17 (A-D), 18 (E-H) e 30 (I) dias de vida pós-natal. Aumento original de 40 x. GSII-FITC contra- corado com brometo de etídio. Contagem de células GSII-positivas /campo em animais de 17 (barra da esquerda) 18 (barra da direita) (J) e 30 dias (K). Cada barra representa a média \pm desvio padrão. $(\mathrm{n})=3-4$ animais por grupo por idade. Em relação ao grupo A: **p<0,01; em relação ao grupo DP: \& p<0,05; \&\&p<0,01.

A reação imuno-histoquímica para mucina 6 foi testada com anticorpos de diversas procedências e padronizada no presente estudo com o anticopo comercial indicado acima. Em filhotes (18 dias), notamos que nos grupos amamentados (A e ARU), a reação foi muito rara (Figura 10A e 7I), enquanto durante o desmame precoce (DP e DPRU), foi identificada na região média da glândula de forma mais ampla (Figura 10B e 7I). Em ratos adultos- jovens 
(30 dias), observamos a marcação para a glicoproteína no citoplasma de células localizadas na interface colo-base da glândula gástrica, indicando CMC e células pré-zimogênicas (Figura 7D- G), e para as nossas análises, consideramos as células na região de colo e no terço inicial da base da glândula (Figura 10).

Os resultados mostraram que o DP promoveu um aumento na distribuição das células secretoras de mucina 6 em filhotes, e este efeito permaneceu em ratos de 30 dias de vida pósnatal $(\mathrm{p}<0,05)$. Em animais de 18 dias, o DP mais que triplicou o número de células, e em animais adultos-jovens, ainda encontramos o dobro de células no grupo DP em relação ao grupo A (Figura 10). Também em animais adultos-jovens, observamos que o tratamento com o antagonista (RU486) diminuiu o número de células imuno-positivas para mucina 6 nos ratos submetidos ao DP $(\mathrm{p}<0,05)$, redução esta de aproximadamente $22 \%$.

Quando confrontamos resultados em filhotes e animais de 30 dias, constatamos, novamente, que a mudança brusca da dieta gerou a antecipação do crescimento do epitélio, uma vez que, comparando índices de marcação para mucina 6 aos 18 e 30 dias, verificamos que nos ratos do grupo A houve um aumentou em $220 \%$, enquanto no grupo DP a variação foi de $30 \%$ (Figura 10I e J). 


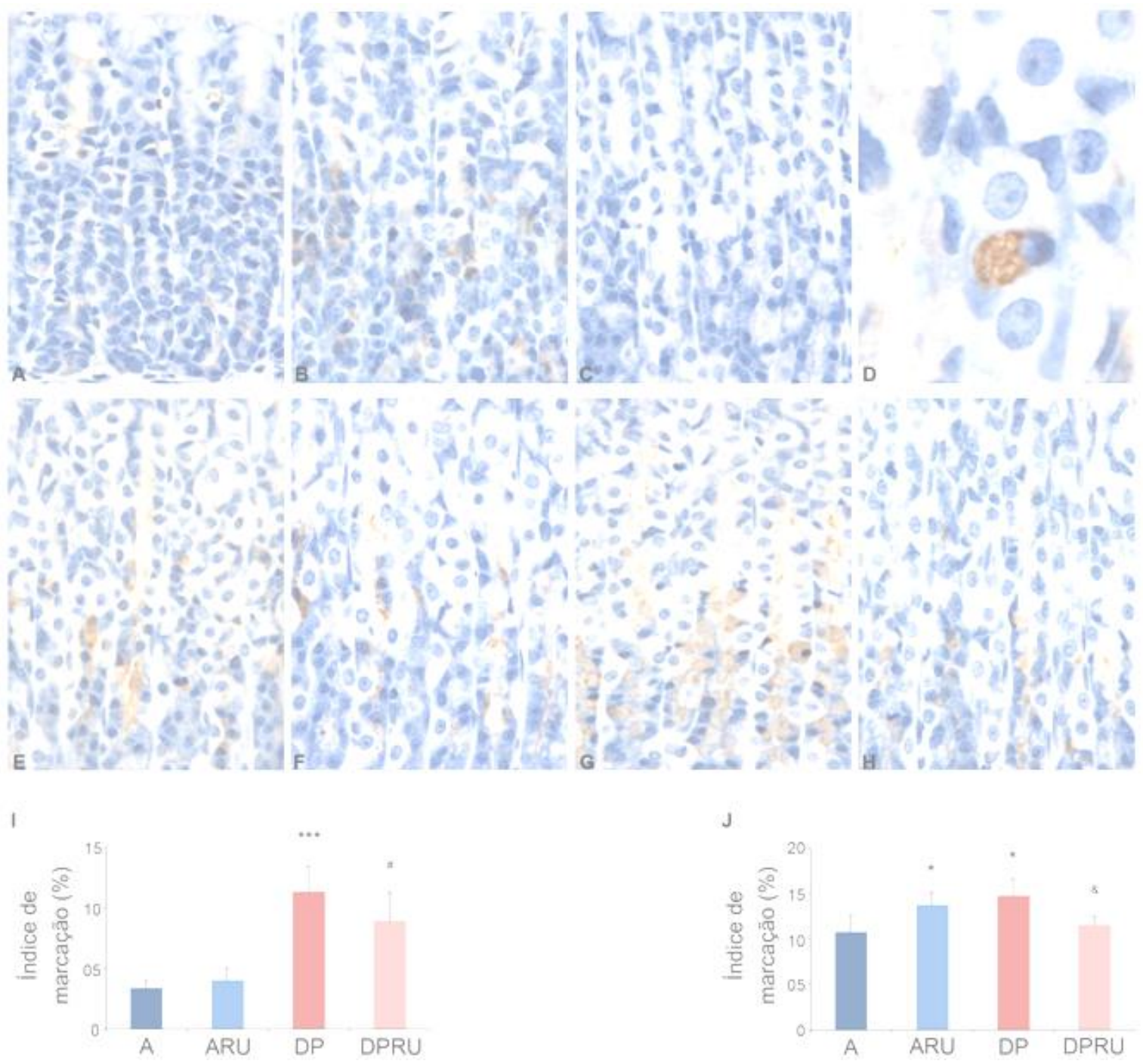

Figura 10 - Avaliação da distribuição de células imuno-marcadas para mucina 6 no epitélio gástrico de ratos submetidos ou não ao desmame precoce e/ou tratados com RU486 ou veículo. Fotomicrografias representativas de reações imuno-histoquímicas para mucina $6 \mathrm{em}$ animais amamentados e injetados com veículo (A, C-E) ou RU486 (F) e animais submetidos ao desmame precoce e injetados com veículo (B e G) ou RU486 (H) aos 18 (AB) e $30(\mathrm{C}-\mathrm{H})$ dias de vida pós-natal. A reação de imuno-histoquímica foi revelada com Liquid DAB+e $\mathrm{H}_{2} \mathrm{O}_{2}$ e contra-corada com Hematoxilina de Mayer. (C) controle negativo da reação. (D) Ampliação digital da região de colo da glândula gástrica evidenciando uma célula mucosa do colo imuno-positiva. Aumento original de 100 x. Índice de marcação (\%) em filhotes (I) e adultos-jovens (J). Cada barra representa a média \pm desvio padrão. (n) $=3$ 4 animais por grupo por idade. Em relação ao grupo A: ${ }^{*} \mathrm{p}<0,05$ e $* * * p<0,0001$; em relação ao grupo ARU: \#p<0,05; em relação ao grupo DP: \&p<0,05.

\subsection{Avaliação da população de células imuno-marcadas para Mist1}

Nos ratos, as células da glândula gástrica atingem completo amadurecimento morfofuncional durante a terceira semana de vida pós-natal, que coincide com o período de transição alimentar ${ }^{15 ; 4}$. As células zimogênicas (CZ) são formadas a partir da diferenciação 
de parte da população de $\mathrm{CMC}^{8 ; 10 ; 11 ; 12}$, pela ação do fator de transcrição Mist1 ${ }^{8 ; 25 ; 26}$. Esse fator regula genes necessários para a diferenciação do aparato secretor de mucinas das CMC para o aparato de secreção serosa, o que identifica as $\mathrm{CZ}^{25 ; 27}$. Para verificar se o DP e/ ou a corticosterona interferem na maturação das $\mathrm{CZ}$, realizamos a contagem das células imunopositivas para Mist1, em animais de 18 e 30 dias, após o DP e o tratamento com o antagonista de corticosterona, o RU486.

Encontramos imuno-marcação para Mist1, em ambas as idades, nos núcleos de células na base da glândula gástrica, caracterizando a população de CZ (Figura 11A-F). Aos 18 dias, o DP gerou um aumento na diferenciação das CZ, uma vez que os filhotes desmamados precocemente apresentaram um número maior de células positivas para Mist1 quando comparados aos animais em amamentação (p<0,0001) (Figura 11J). Contudo, o bloqueio da corticosterona não provocou efeitos sobre a distribuição das células imuno- marcadas para Mist1. 

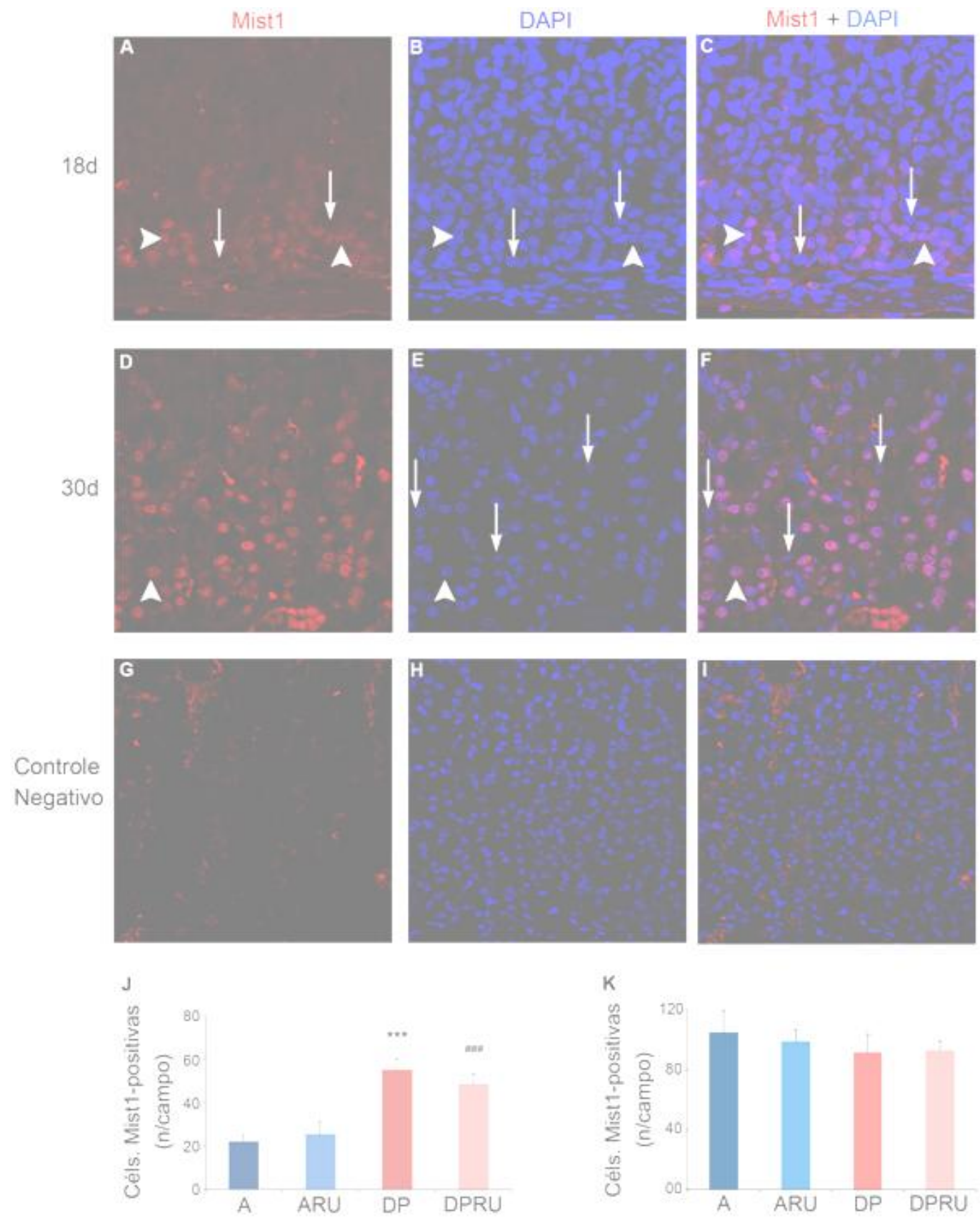

Figura 11 - Avaliação da distribuição das células imuno-marcadas para Mist1 no epitélio gástrico de ratos submetidos ou não ao desmame precoce e/ou tratados com RU486 ou veículo. Fotomicrografias representativas de reações imuno-histoquímicas para Mist1 (A-I) em animais amamentados e injetados com veículo aos 18 (A-C) e 30 (D-I) dias de vida pósnatal. A reação de imuno-histoquímica para Mist1 foi revelada com anticorpo conjungado a Cy3 (A, D e G) e contra- corada com DAPI (B, E e H). (C, F e I) sobreposição das imagens da primeira e segunda coluna. (G-I) Controle negativo da reação. (A-F) As setas apontam células epiteliais não-marcadas e as cabeças de seta, células epiteliais imuno-marcadas. Aumentos originais: 40 x (G-I) e 63x (A-F). Células imuno- marcadas para Mist1/campo em filhotes $(\mathrm{J})$ e adultos-jovens $(\mathrm{K})$. Cada barra representa a média \pm desvio padrão. $(\mathrm{n})=$ 3-4 animais por grupo por idade. Em relação ao grupo A: ***p<0,0001; em relação ao grupo ARU: \#\#\#p<0,0001. 
Dos 18 aos 30 dias de vida pós-natal, registramos uma ampliação importante no número de células imuno-positivas/campo ( $\mathrm{p}<0,0001)$ (Figura 11J e K), sendo que, para os animais amamentados, o aumento foi três vezes maior que o observado em ratos em DP. Este resultado corrobora o importante papel da mudança da dieta na maturação precoce da glândula gástrica, já constatado no estudo da população de $\mathrm{CMC}^{49}$. Todavia, para as amostras de 30 dias, não detectamos diferenças significativas entre os diferentes tratamentos.

\subsection{Avaliação da população de células imuno-marcadas para PGC}

Como mencionado anteriormente, as CZ são secretoras de proteínas, sendo um dos principais produtos o pepsinogênio. Diferentes tipos e quantidades de pepsinogênio são produzidos de acordo com o estado de maturação da mucosa gástrica ${ }^{30 ; 31} \mathrm{e}$, em ratos, o PGC é considerado marcador do desenvolvimento deste epitélio ${ }^{113}$. Então, para verificarmos se o DP e/ou a corticosterona afetam a população de $\mathrm{CZ}$, realizamos reação de imuno-histoquímica para pepsinogênio e pepsina $\mathrm{C}$, em amostras de animais de 18 e 30 dias, após o DP e o bloqueio da corticosterona com o RU486, e avaliamos o número de células positivas.

A reação de imuno-histoquímica nos permitiu evidenciar tanto as $\mathrm{CZ}$ produtoras de PGC na base da glândula gástrica quanto a pepsina C (forma ativa da molécula) encontrada no lúmen do estômago, e sobre a membrana das células parietais (Figura 12A- H). Porém, para a avaliação dos efeitos do DP e da corticosterona sobre o desenvolvimento do estômago, apenas a reação citoplasmática e de membrana nas $\mathrm{CZ}$ foi considerada. 


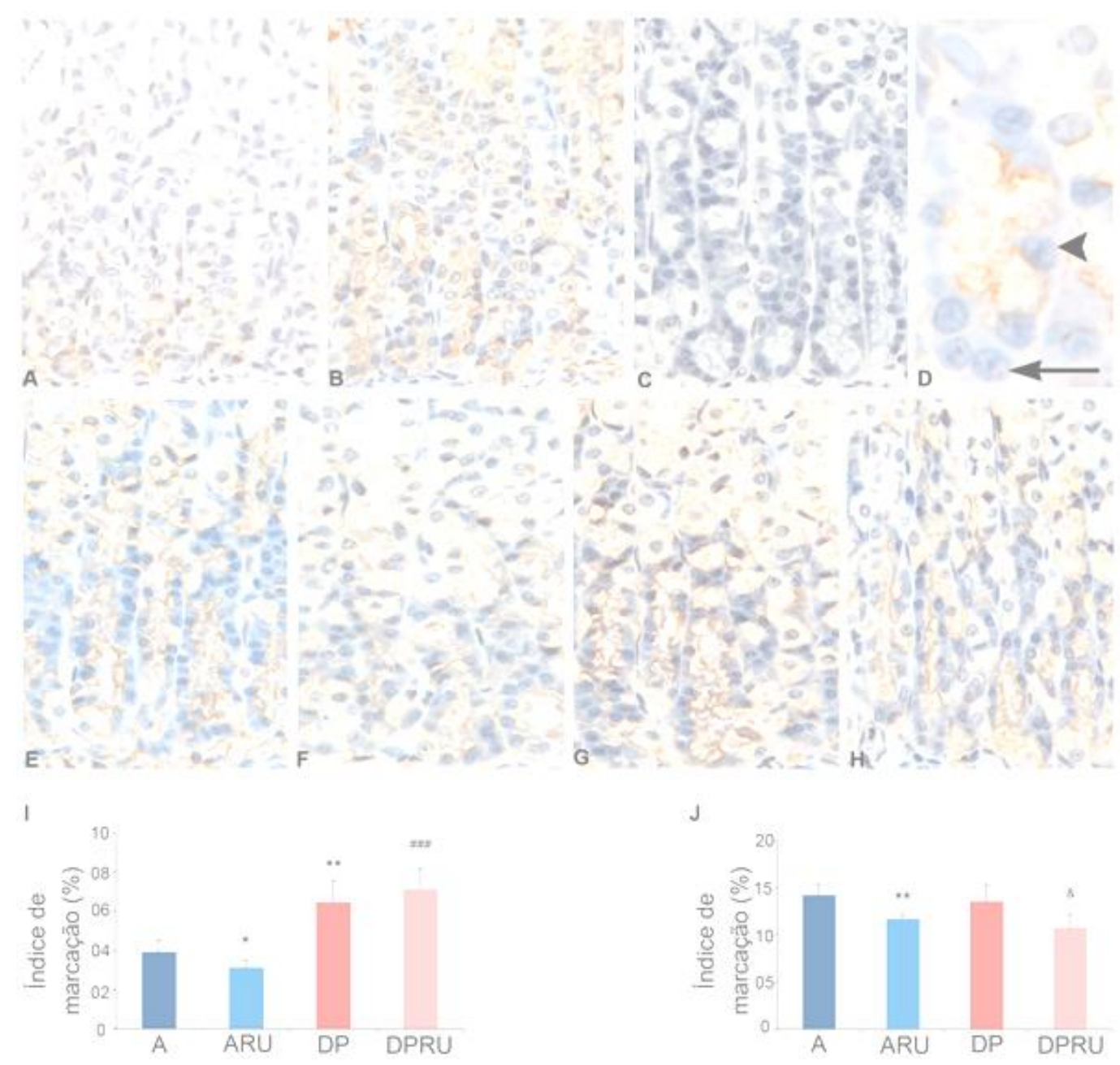

Figura 12 - Avaliação da distribuição das células imuno-marcadas para pepsinogenio C no epitélio gástrico de ratos submetidos ou não ao desmame precoce e/ou tratados com RU486 ou veículo. Fotomicrografias representativas de reações imuno-histoquímicas para pepsinogênio $\mathrm{C}(\mathrm{A}-\mathrm{H})$ em animais amamentados e injetados com veículo (A, C-E) ou RU486 (F) e animais submetidos ao desmame precoce e injetados com veículo (B e G) ou RU486 $(\mathrm{H})$ aos $18(\mathrm{~A}-\mathrm{B})$ e $30(\mathrm{C}-\mathrm{H})$ dias de vida pós-natal. A reação de imunohistoquímica foi revelada com Liquid DAB+e $\mathrm{H}_{2} \mathrm{O}_{2}$ e contra- corada com Hematoxilina de Mayer. (C) controle negativo da reação. (D) Na ampliação digital da base da glândula gástrica, a cabeça de seta aponta uma célula zimogênica imuno-marcada para pepsinogenio $\mathrm{C}$ e a seta indica uma célula zimogênica não marcada. Aumento original: 100 x. Índice de marcação (\%) para pepsinogênio $\mathrm{C}$ em filhotes (I) e adultos-jovens (J). Cada barra representa a média \pm desvio padrão. $(\mathrm{n})=3-4$ animais por grupo por idade. Em relação ao grupo A: ${ }^{*} \mathrm{p}<0,05$ e ${ }^{* *} \mathrm{p}<0,01$; em relação ao grupo ARU: \#\#\#p<0,0001; em relação ao grupo DP: \& $\mathrm{p}<0,05$.

Em filhotes, o DP aumentou o número de CZ imuno- marcadas para PGC em 65\% quando comparado ao grupo A ( $\mathrm{p}<0,01)$ (Figura 8I). Observamos também, que o antagonista RU486 reduziu de maneira significativa em aproximadamente $20 \%$, o número de CZ positivas apenas nos animais amamentados $(\mathrm{p}<0,05)$, e não induziu alterações no grupo DPRU (Figura 12I). 
Nos animais de 30 dias, verificamos que o efeito provocado pelo DP não prevaleceu, porém a redução no número de CZ positivas, ocorrida pela ação do RU486, se manteve no grupo ARU $(\mathrm{p}<0,01)$ (Figura 9J) e, além disso, pudemos notar que o bloqueio da corticosterona diminuiu também a população de CZ imuno-marcadas nos animais DPRU $(\mathrm{p}<0,05)$ (Figura 12J). Quando comparamos os grupos A e ARU, DP e DPRU, aos 30 dias, verificamos que a redução no número de $\mathrm{CZ}$ imuno-positivas ocasionada pelo antagonista foi de aproximadamente $20 \%$, em ambos os casos. 


\section{DISCUSSÃO}

A mucosa gástrica do rato atinge seu estágio final de diferenciação celular durante a terceira semana de vida pós-natal. É neste período que também ocorre a transição alimentar, em que a dieta muda gradativamente do leite materno para a ingestão de ração ${ }^{14 ; 15}$. O modelo de desmame precoce consiste na abrupta interrupção da amamentação e substituição desta pelo consumo da ração ${ }^{47 ;} 48$, o que pode ocasionar efeitos sobre a maturação de diversos órgãos e sistemas ${ }^{47 ;} 58$ além de elevação imediata dos níveis de corticosterona ${ }^{46 ; 53}$. No estômago, o DP está relacionado com o aumento da diferenciação de $\mathrm{CMC}^{49}$ e $\mathrm{CZ}^{46}$. No presente estudo, o objetivo foi avaliar o papel da corticosterona sobre a maturação da mucosa gástrica durante o desmame precoce, e verificar se os efeitos da mudança de padrão alimentar e da corticosterona são mantidos em animais adultos-jovens.

O leite materno não é apenas uma fonte de macro- nutrientes para o recém-nascido. É por meio deste alimento que o filhote deve receber moléculas biologicamente ativas até atingir a adequada maturação para produzir seus próprios hormônios e fatores de crescimento 42; 45; 114 . Um estudo recente mostrou que os anticorpos secretados no leite no período de amamentação regulam a expressão gênica, e a microbiota do intestino de animais adultos ${ }^{43}$, ou seja, efeitos da fase de amamentação são mantidos tardiamente. Como já mencionado, sabe-se que durante a amamentação, alterações no padrão alimentar podem induzir perturbações no desenvolvimento do organismo, incluindo o trato gastrintestinal. Dentre essas alterações, as mais comuns são separação materno- neonatal, desmame precoce e desnutrição. A separação materno- neonatal pode provocar efeitos deletérios de longa duração na motilidade intestinal ${ }^{115 ;}{ }^{116}$. Resultados de nosso laboratório mostraram que filhotes submetidos à separação materno- neonatal também apresentam aumento da secreção de corticosterona e de seu binding ao GR nuclear na mucosa gástrica ${ }^{77}$, enquanto outro estudo mostrou que há hiper-metilação próxima à região promotora do gene codificante de GR $(\mathrm{Nr} 3 \mathrm{cl})$, comprovando o efeito epigenético ${ }^{63}$. Cabe ressaltar que essas alterações persistem até a idade adulta, indicando que a perturbação do padrão alimentar e comportamental induzida pela separação materno-neonatal reprograma funções durante o crescimento ${ }^{63 ; 77}$.

Em nosso presente modelo, temos a retirada brusca do leite e a separação do filhote de sua mãe, que associados constituem o desmame precoce, e diferentes estudos mostram que animais submetidos a esse tratamento exibem uma maturação prematura de diversos órgãos e sistemas biológicos $46 ; 47 ; 58 ; 106$. Filhotes de porcos vocalizam, permanecem de pé e exploraram o ambiente mais cedo que os lactentes ${ }^{58}$, enquanto filhotes de coelho apresentam maior peso 
dos órgãos que formam o aparelho digestório ${ }^{117}$. Observamos que os filhotes de rato em DP exploram o ambiente rapidamente aos 17 dias de vida pós- natal e já seguram o pellet de ração, e nossos resultados mostram que no início da mudança da dieta, ocorreu redução na massa corpórea total, corroborando estudos anteriores ${ }^{47 ; 48}$. No intestino, o DP provoca um aumento prematuro na atividade enzimática da sacarase ${ }^{47}$, no conteúdo de DNA e proteína ${ }^{46}$, e na densidade de linfócitos ${ }^{58}$. Estudos anteriores de nosso laboratório encontraram que no epitélio gástrico, o DP aumenta a proliferação celular ${ }^{48}$, número de células mucosas do colo 49, e modifica a distribuição de fator de crescimento transformante- $\beta 3^{51}$ e de células produtoras de ghrelina ${ }^{52}$, além de modificar a atividade da corticosterona ${ }^{53}$. Também devemos mencionar que o EGFR está envolvido tanto na diferenciação quanto na proliferação celular gástrica estimulada pelo DP ${ }^{49 ; 50}$, e que essas respostas dependem de sinalização por MAPK $^{118}$.

No presente estudo, observamos que em filhotes, o DP aumentou a expressão de alguns genes marcadores da diferenciação da mucosa gástrica como o Muc5ac (células mucosas superficiais), Muc6 (mucosas do colo), Bhlha15 e Pgc (zimogênicas). A influência do DP sobre a maturação deste epitélio já havia sido descrita observando-se a expressão de Muc6 ${ }^{49}$ e a atividade da pepsina ${ }^{106}$. Todavia, este é o primeiro estudo que demonstrou o efeito do DP na expressão de diversos genes que caracterizam distintas populações celulares formadoras da glândula gástrica, reafirmando o importante papel do período regular de amamentação sobre a maturação deste epitélio.

Dentre as secreções gástricas, diferentes tipos e quantidades de pepsinogênio são produzidos e liberados pela glândula gástrica de acordo com o seu grau de desenvolvimento 30; 31 . Pudemos observar a indução de maturação promovida pelo DP, pois em ratos de 17 dias, vimos que enquanto que o DP elevou a expressão gênica de $P g c$ (codificante do pepsinogênio C, secretado por CZ maduras), o efeito oposto foi observado em relação ao Pga5 (pepsinogênio imaturo). Assim, o estímulo imediato do DP parece ocorrer sobre o processo de diferenciação de cada tipo celular, modificando a constituição do produto de secreção dessas células que, no caso dos diferentes pepsinogênios, é correlacionada com a mudança no principal constituinte da dieta, inicialmente o leite materno, e posteriormente a ração.

Ao avaliarmos a progressão da resposta ao DP, notamos que nos animais adultosjovens, a expressão de $P g c$ se manteve alta, o que indica o caráter duradouro do efeito sobre a célula, frente à mudança da dieta ocorrida na terceira semana de vida pós- natal. Em nosso estudo, não temos observações que sugiram que as modificações encontradas na mucosa gástrica estejam diretamente relacionadas a patologias, porém mostramos que o DP provocou 
mudanças gênicas e estruturais no epitélio que perduraram até a idade adulta. Esses achados concordam com a hipótese de Barker, que relaciona estímulos ambientais ocorridos em períodos críticos do desenvolvimento com a "programação" na vida adulta 64; 65. Assim, embora análises mais detalhadas sobre aspectos fisilógicos e epigenéticos sejam necessárias, o DP parece ocasionar um processo de pré-ativação (ou priming, em inglês) do organismo em vários tecidos.

Dentre as respostas ao desmame precoce, sabe-se que esta condição leva ao aumento da corticosterona plasmática e modifica a atividade desse hormônio ${ }^{46 ; 53}$. Para analisar as possíveis implicações da elevação hormonal e da ação de seu receptor sobre o epitélio gástrico em desenvolvimento, ratos foram injetados com o RU486, que age através do bloqueio de GR ${ }^{87 ; 119}$. Embora a eficiência na mucosa gástrica já houvesse sido testada por meio da translocação de GR do citoplasma para o núcleo em células epiteliais (Ghizoni et al., 2014), fez-se necessário atestarmos a função deste antagonista em nosso modelo por meio da medida do RNAm de $S g k{ }^{63 ; 92 ; 93}$. Os glicocorticoides agem elevando a expressão de $S g k 1$ no estômago ${ }^{92}$ e em outros tecidos ${ }^{63}$. De maneira semelhante, o estresse provocado pelo DP aumentou os níveis de $S g k l$ e o uso do antagonista reduziu essa resposta. Em linhagens celulares de câncer de próstata, o tratamento com dexametasona também eleva a expressão de Sgkl e a adição concomitante de RU486 anula a ação do glicocorticoide, entretanto nenhum efeito foi observado nos níveis de $\mathrm{Nr3cl}$ (gene codificante de GR) ${ }^{120}$, dado que foi corroborado por nossas análises. Nossos resultados sugeriram que a administração de RU486 agiu sobre a expressão de $S g k 1$ na condição DP em que a atividade da corticosterona estava aumentada (Ghizoni et al., 2014), e assim, podemos considerar que a eficiência do antagonista foi maior no desmame precoce em comparação à amamentação.

Em relação ao papel da corticostserona durante o desmame precoce, verificamos que o RU486 reverteu o efeito do DP sobre $M u c 5 a c$ e $P g c$ em ratos de 17 dias, indicando a relação primordial do hormônio nesses genes. Entretanto, houve aumento de Muc6 nos filhotes amamentados. Estudos apontam o papel controverso dos glicocorticoides sobre genes codificadores de mucinas e a variabilidade entre as proteínas constituintes do muco. As mucinas podem ser classificadas em secretadas, em direção ao conteúdo mucoso extracelular, e não-secretadas, fazem parte do muco, porém ficam ancoradas na membrana plasmática ${ }^{22}$. Em células epiteliais nasais, o tratamento com dexametasona é capaz de aumentar o RNAm da mucina $16^{99}$ e da mucina 1 , localizadas na membrana plasmática, e da mucina 8 , que é secretada. Entretanto, o mesmo tratamento diminui a expressão de $M u c 5 b$, gene codificante de 
outra mucina secretada ${ }^{98}$. Cabe ressaltar que o aumento de mucina 16 é revertido pela ação de RU486 ${ }^{99}$.

Nossas análises indicaram um possível papel da corticosterona sobre as mucinas 5AC e 6. No entanto, devemos considerar que a síntese de mucinas envolve diversas etapas, desde a transcrição gênica até a secreção final, e essas fases podem ser reguladas diferentemente por uma infinidade de fatores de crescimento, incluindo TGF- $\alpha$, EGFR, EGF e TNF- $\alpha$ 49; 121; 122; 123; 124, além de hormônios e enzimas de glicosilação. A influência do EGFR sobre a diferenciação provocada pelo DP já foi descrita no nosso laboratório, e sabe-se também que a sinalização celular desencadeada por este receptor é capaz de promover a expressão gênica de mucinas ${ }^{125}$.

As mucinas são glicoproteínas de alto peso molecular, com grande quantidade de oligossacarídeos, constituintes do muco protetor que recobre o trato gastrintestinal ${ }^{17 ;} 18$. No estômago, a mucina 6 é secretada exclusivamente pelas CMC associada aos antígenos de Lewis de tipo 2 ( $\mathrm{Le}^{\mathrm{x}}$ and $\mathrm{Le}^{\mathrm{y}}$ ), já a mucina $5 \mathrm{AC}$ é secretada unicamente pelas células mucosas superficiais em associação aos antígenos de Lewis de tipo $1\left(\operatorname{Le}^{\mathrm{a}}\right.$ and $\left.\mathrm{Le}^{\mathrm{b}}\right)$. Ambos os tipos de antígenos são sintetizados pela ação da enzima $\alpha$-1,2-fucosiltranferase, e no epitélio gástrico, a expressão gênica de fucosiltranferases está organizada de forma que os genes Fut2 e Fut3 são encontrados na fosseta, enquanto que Futl e Fut3 são encontrados na glândula ${ }^{112}$. A atividade e expressão de enzimas de glicosilação são baixas após o nascimento, e aumentam rapidamente na fase de desmame com a mudança na dieta ${ }^{126}$. Durante este período, os glicocorticoides induzem a glicosilação de enzimas da borda em escova e a fucosilação de mucinas. A expressão de fucosiltransferase também aumenta em filhotes amamentados tratados com hidrocortisona, mas os níveis ainda são menores do que em ratos adultos. Além disso, a RU486 reverte as atividades da galactosyl- e $\alpha$-1,2-fucosiltransferase após o tratamento com hidrocortisona ${ }^{102}$.

A fim de verificar possíveis efeitos do DP e dos glicocorticoides sobre a glicosilação de mucina 6, buscamos estudar a expressão de Fut1. Nossos resultados apontaram para uma redução de Futl com o uso do antagonista de corticosterona em filhotes amamentados, e também uma diminuição em ratos de 30 dias submetidos ao DP. Embora, sejam observações distintas nas duas idades, uma dependente da corticosterona, e outra do padrão alimentar, até o presente momento, não se tem conhecimento de outros estudos que abordem o DP e o gene Fut1. Podemos extrapolar nossas observações sobre a glicosilação da mucina 6 e questionar a existência de uma relação entre a diminuição da expressão de Futl, encontrada neste estudo, e o aumento da taxa de infecção por Escherichia coli descrita em animais submetidos ao DP ${ }^{127}$; 
128, já que Fut1 também poderia contribuir no papel protetor do muco que recobre o trato gastrintestinal. Apesar das interações patógeno-hospedeiro estarem muito além de nossos objetivos, infecções entéricas são importantes na mortalidade e morbidade entre humanos ${ }^{129} \mathrm{e}$ em animais de grande relevância econômica ${ }^{130}$. Estudos indicaram que animais menos resistentes a Escherichia coli possuem reduzida expressão de Futl ${ }^{131}$ e que o aumento da dificuldade de reagir a infecções por esta enterobactéria, provocado pelo DP persiste até a fase pós- desmame ${ }^{132}$.

Em relação à expressão de $P g c$ após tratamento com RU486, observamos uma redução, conforme proposto por outros autores ${ }^{96 ; 97}$, que demonstraram o envolvimento dos glicocorticoides na maturação das CZ. O efeito que notamos permaneceu em ratos adultosjovens, indicando que a ação da corticosterona no início do desmame precoce afetou de forma permanente a expressão de $P g c$. A ação de glicorticoides sobre o PGC também é demonstrada pela presença de 4 regiões com alta afinidade a ligação com o GR no gene codificante deste zimógeno $^{77}$.

Nossos resultados evidenciaram também que o tratamento com RU486 diminuiu a expressão de Pga5 em animais de 30 dias, confirmando dados de outros pesquisadores que observaram uma redução na secreção de pepsinogênio por CZ imaturas após adrenalectomia 133. Assim, o efeito do DP no desenvolvimento da mucosa gástrica é mediado, mesmo que parcialmente, pela corticosterona que parece agir diretamente sobre o papel secretor das células, aumentando ou reduzindo a expressão dos constituintes finais do produto de secreção.

O desenvolvimento da mucosa gástrica foi avaliado considerando-se não apenas a expressão de genes, mas também a distribuição da linhagem de CMC e CZ, por representarem a etapa final de diferenciação deste epitélio ${ }^{6 ; 8 ; 11}$. As CMC foram analisadas pelo emprego de diferentes técnicas de histoquímica e imuno-histoquímica. Por se tratarem de células que secretam glicoproteínas com alto teor de oligossacarídeos ${ }^{21 ; 22}$, o uso da metodologia diversa permitiu uma análise completa e detalhada de toda a população de CMC, desde células produtoras de muco ácido (evidenciado pelo $\mathrm{AB}$ ) ${ }^{134}$, células que secretam mucinas com alta afinidade a lectina GSII ${ }^{135}$ e células que, na região do corpo gástrico, são as únicas secretoras de mucina $6^{108}$.

A avaliação da população de CMC em ratos de 17 e 18 dias indicou, mais uma vez, que o DP acelera a maturação da mucosa gástrica ${ }^{47}$ através do aumento no número de CMC 49 e que existe um importante papel da corticosterona sobre este efeito. Esses resultados foram obtidos, em maior ou menor proporção, nas três técnicas utilizadas, embora a diminuição na quantidade de células imuno-marcadas para mucina 6, quando comparamos os grupos DP e 
DPRU, não tenha significância estatística. A ação da corticosterona sobre células secretoras de muco já havia sido demonstrada em outros trabalhos ${ }^{98 ; 136}$. Um estudo realizado com camundongos Winnie (este modelo apresenta deficiência na produção de mucina 2, que é a maior constituinte do muco intestinal) evidenciou um aumento no número de células PASABpositivas na reagião do cólon após tratamento com dexametasona ${ }^{136}$. Cabe destacar que, até o presente momento, não temos conhecimento de outro trabalho que tenha mostrado células imuno-positivas para mucina 6 no estômago de ratos, e mesmo em outras espécies os desafios da imuno-detecção da mucina 6 são relatados ${ }^{137}$.

Nossos resultados mostraram que as alterações causadas nas CMC de filhotes pelo DP e pelo bloqueio do GR foram mantidas até a idade adulta. Novamente, embora a análise com a lectina GSII não aponte um resultado estatisticamente significativo, observamos, em todas as técnicas realizadas em ratos de 30 dias, que a elevação no número de CMC provocada pelo DP se manteve e que houve uma redução nesta população celular quando comparados os animais DP e DPRU. Outros autores relataram que os prejuízos causados pelo DP na barreira jejunal também são mantidos em longo prazo ${ }^{57}$. No nosso modelo, a corticosterona (elevada pelo estresse da precoce interrupção da amamentação), mostrou-se capaz de modificar o número de CMC não apenas no momento imediatamente após a mudança de dieta, mas sim, até a fase adulta, o que poderia acarretar consequências fisiológicas futuras, por se tratarem de células com importante papel protetor para o epitélio gástrico. As CMC não apenas protegem a mucosa contra o $\mathrm{pH}$ ácido ${ }^{20}$, mas também, contra a ação de bactérias como o Helicobacter pylori $^{19}$. Em conjunto, todos esses resultados reforçam a importante necessidade de se evitar perturbações na relação materno-infantil que possam gerar alterações hormonais e na ação dos glicocorticoides.

Devemos destacar também o papel relevante das CMC na origem das células zimogênicas ${ }^{6 ; 11}$, processo no qual Mist1 é um fator de transcrição que induz a mudança do aparato secretor de CMC (secreção glicoproteinca) ${ }^{22}$ para CZ (secreção proteica) ${ }^{25 ; 26}$. Por meio de reações de imuno-fluorescência e imuno-histoquímica, vimos que o DP aumentou o número de células imuno-marcadas para Mist1 e para PGC em filhotes, o que corrobora e complementa trabalhos prévios que descrevem uma maior diferenciação de $\mathrm{CZ}$ após o DP ${ }^{106}$. Todavia, apenas os resultados para PGC foram mantidos em ratos adultos. Estudos anteriores indicaram que a hidrocortisona também age na maturação de $\mathrm{CZ}^{96 ; 97}$, o que não foi por nós constatado na identificação de células Mist1-positivas.

Em filhotes, a maturação da população de CZ não está completamente estabelecida ${ }^{14}$, e a expressão de Mist1 pode ser considerada como uma etapa inicial na diferenciação dessas 
células ${ }^{26}$, uma vez que precede a organização baso-apical, e a adequada maturação dos grânulos de PGC 27; 28; 138 . Assim, se consideramos o tempo de ação do RU486 em nosso modelo (estágios inicias do desmame precoce), encontramos evidências de que a corticosterona não age nas etapas iniciais de diferenciação das $\mathrm{CMC}$ em $\mathrm{CZ}$, porém tem papel fundamental na produção de PGC.

Devemos destacar que no último ano, um longo e detalhado estudo comprovou a existência de células-tronco positivas para Mist1 localizadas no istmo da glândula gástrica 5 . Em nossas análises, não avaliamos esse padrão de distribuição, e dessa forma, não podemos afirmar se o DP e a corticosterona modificam essa população. Como o estabelecimento deste fator de transcrição como marcador de células-tronco gástricas é muito recente, novos estudos neste tema devem ser conduzidos, mas é importante frisar que essa descoberta vem fomentar os debates a respeito da origem do câncer gástrico, direcionando a terapêutica em relação à diferenciação e renovação deste epitélio ${ }^{139}$.

Através das análises obtidas neste estudo, pudemos destacar mais uma vez, o importante papel do período de amamentação na maturação celular. A Figura 13 apresenta um resumo dos resultados obtidos, que vêm expandir a pesquisa sobre o papel do DP na maturação gástrica, e mostrar que os efeitos observados imediatamente após a mudança da dieta, sobre a população de CMC e células secretoras de PGC, persistem até a idade adulta. Por meio do bloqueio de GR, evidenciamos que a corticosterona apresenta importante papel no desenvolvimento do epitélio gástrico, agindo como um estimulador da maturação celular. Entretanto, são necessários novos estudos, no âmbito da biologia molecular e de morfologia celular, para que possamos elucidar os mecanismos de ação dos glicorticoides e quais as moléculas estão diretamente envolvidas no processo de regulação da diferenciação celular.

Dessa forma, os resultados obtidos em nosso estudo associados às evidencias até hoje encontradas alertam para o fato de que a abrupta interrupção do aleitamento é capaz de induzir alterações na atividade da corticosterona, que por sua vez podem perturbar o desenvolvimento do estômago. 
Filhotes de $17 \mathrm{~d}$ e $18 \mathrm{~d}$

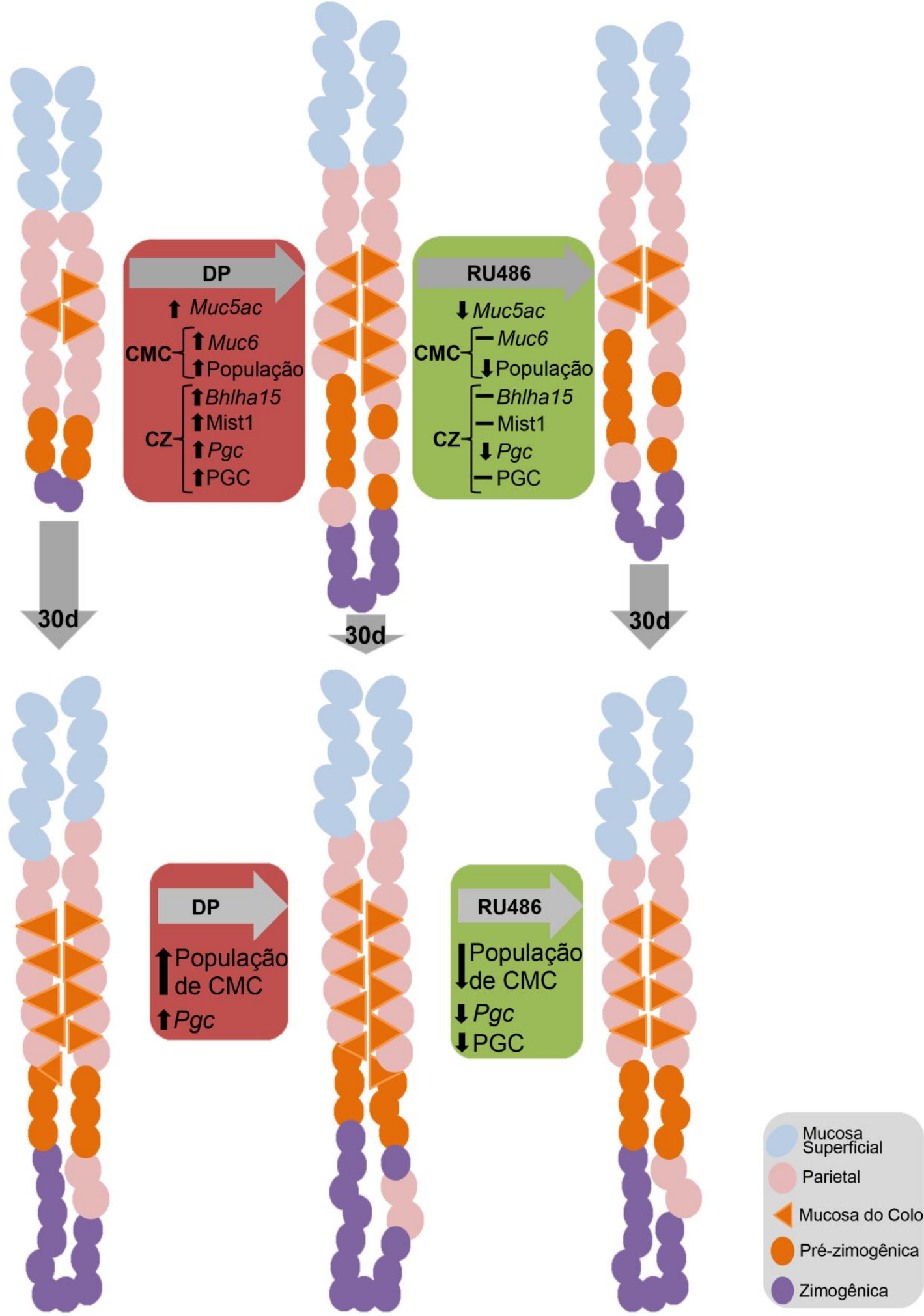

Figura 13 -Representação esquemática dos resultados obtidos neste estudo. O DP caracterizado pelo aumento da atividade da corticosterona causou os efeitos sobre as populações celulares secretoras da glândula gástrica de ratos filhotes e adultos-jovens. A ação do antagonista RU486 reduziu a função da corticosterona e também interferiu sobre a diferenciação celular deste epitélio. 


\section{CONCLUSÕES}

Nossos resultados permitem constatar que:

1) O desmame precoce aumentou a expressão dos genes Bhlha15, Pgc, Muc5ac e Muc6, marcadores da maturação da glândula gástrica, sendo que para os genes $P g c$ e $M u c 5 a c$ essa reposta é desencadeada pela elevação da corticosterona após a mudança da dieta;

2) A corticosterona possui importante papel sobre a diferenciação das células mucosas do colo acelerada pelo desmame precoce;

3) O desmame precoce aumentou a expressão de Mist1, tanto no RNAm quanto no número de células imuno-marcadas;

4) $O$ desmame precoce aumentou a diferenciação das células zimogênicas, reduzindo a expressão gênica do pepsinogênio imaturo (Pga5) e elevando a expressão de $P g c$ (pepsinogênio maduro), além de aumentar o número de células PGC-positivas. A resposta do gene $P g c$ também foi mediada pela corticosterona elevada pelo desmame precoce;

5) Os efeitos do desmame precoce sobre a diferenciação das células mucosas do colo e sobre o RNAm dos dois pepsinogênios foram mantidos até os 30 dias de vida pósnatal;

6) Os efeitos do bloqueio de GR na população de células mucosas do colo e zimogênicas também persistiram até a idade adulta.

Nossos resultados indicaram que o aumento da maturação do epitélio gástrico, desencadeado pelo DP, pode ser mediado por diversos fatores, cujos efeitos são capazes de perdurar até a idade adulta. Todavia, quando consideramos o desenvolvimento das populações de células mucosas do colo e zimogênicas, podemos concluir que a corticosterona é um estímulo fundamental no aumento da diferenciação dessas células, e o desmame precoce funciona como um gatilho para esses processos. 


\section{REFERÊNCIAS $^{1}$}

LEE, E. R. et al. Division of the mouse gastric mucosa into zymogenic and mucous regions on the basis of gland features. Am J Anat, v. 164, n. 3, p. 187-207, Jul 1982. ISSN 0002-9106. Disponível em: < http://www.ncbi.nlm.nih.gov/pubmed/7124652 >.

FIORE, A. P. Z. P. Regulação de p27 pelo fator de crescimento transformante $\beta 1$ (TGFß1) na mucosa gástrica de ratos lactentes. 2013. $88 \mathrm{f}$. Tese (Doutorado em Ciências). Instituto de Ciências Biomédicas, Universidade de São Paulo, São Paulo, 2013.

EKELUND, M. et al. Endocrine cells and parietal cells in the stomach of the developing rat. Acta Physiol Scand, v. 124, n. 4, p. 483-497, Aug 1985. ISSN 00016772. Disponível em: < http://www.ncbi.nlm.nih.gov/pubmed/2864780 >.

JAIN, R. N.; SAMUELSON, L. C. Differentiation of the gastric mucosa. II. Role of gastrin in gastric epithelial cell proliferation and maturation. Am J Physiol Gastrointest Liver Physiol, v. 291, n. 5, p. G762-765, Nov 2006. ISSN 0193-1857. Disponível em: < http://www.ncbi.nlm.nih.gov/pubmed/17030897 >.

HAYAKAWA, Y. et al. Mist1 Expressing Gastric Stem Cells Maintain the Normal and Neoplastic Gastric Epithelium and Are Supported by a Perivascular Stem Cell Niche. Cancer Cell, v. 28, n. 6, p. 800-814, Dec 2015. ISSN 1878-3686. Disponível em: < http://www.ncbi.nlm.nih.gov/pubmed/26585400 >. Epithelium. Int J Mol Sci, v. 16, n. 8, p. 19153-19169, 2015. ISSN 1422-0067. Disponível em: < http://www.ncbi.nlm.nih.gov/pubmed/26287172 >.

7 KARAM, S. M.; LEBLOND, C. P. Dynamics of epithelial cells in the corpus of the mouse stomach. I. Identification of proliferative cell types and pinpointing of the stem cell. Anat Rec, v. 236, n. 2, p. 259-279, Jun 1993. ISSN 0003-276X. Disponível em: < http://www.ncbi.nlm.nih.gov/pubmed/8338232 >.

MILLS, J. C.; SHIVDASANI, R. A. Gastric epithelial stem cells. Gastroenterology, v. 140, n. 2, p. 412-424, Feb 2011. ISSN 1528-0012. Disponível em: < http://www.ncbi.nlm.nih.gov/pubmed/21144849 >. generate all lineages of the stomach epithelium. Cell, v. 155, n. 2, p. 357-368, Oct

\footnotetext{
${ }^{1}$ De acordo com: ASSOCIAÇÃO BRASILEIRA DE NORMAS TÉCNICAS. NBR 6023: informação e documentação: referências: elaboração. Rio de Janeiro, 2002.
} 
2013. ISSN 1097-4172. Disponível em: <

http://www.ncbi.nlm.nih.gov/pubmed/24120136 >.

KARAM, S. M.; LEBLOND, C. P. Dynamics of epithelial cells in the corpus of the mouse stomach. II. Outward migration of pit cells. Anat Rec, v. 236, n. 2, p. 280-296, Jun 1993. ISSN 0003-276X. Disponível em: < http://www.ncbi.nlm.nih.gov/pubmed/8338233 >.

Dynamics of epithelial cells in the corpus of the mouse stomach. III. Inward migration of neck cells followed by progressive transformation into zymogenic cells. Anat Rec, v. 236, n. 2, p. 297-313, Jun 1993. ISSN 0003-276X. Disponível em: < http://www.ncbi.nlm.nih.gov/pubmed/8338234 >.

KARAM, S. M. Dynamics of epithelial cells in the corpus of the mouse stomach. IV. Bidirectional migration of parietal cells ending in their gradual degeneration and loss. Anat Rec, v. 236, n. 2, p. 314-332, Jun 1993. ISSN 0003-276X. Disponível em: < http://www.ncbi.nlm.nih.gov/pubmed/8338235 >.

BARKER, N. et al. Lgr5(+ve) stem cells drive self-renewal in the stomach and build long-lived gastric units in vitro. Cell Stem Cell, v. 6, n. 1, p. 25-36, Jan 2010. ISSN 1875-9777. Disponível em: < http://www.ncbi.nlm.nih.gov/pubmed/20085740 >.

KEELEY, T. M.; SAMUELSON, L. C. Cytodifferentiation of the postnatal mouse stomach in normal and Huntingtin-interacting protein 1-related-deficient mice. Am J Physiol Gastrointest Liver Physiol, v. 299, n. 6, p. G1241-1251, Dec 2010. ISSN 1522-1547. Disponível em: < http://www.ncbi.nlm.nih.gov/pubmed/20813912 >.

IHIDA, K. et al. Glycoconjugate histochemistry of the rat fundic gland using Griffonia simplicifolia agglutinin-II during the development. Am J Anat, v. 182, n. 3, p. 250-256, Jul 1988. ISSN 0002-9106. Disponível em: < http://www.ncbi.nlm.nih.gov/pubmed/3213823 >.

JOHNSON, L. R. Functional development of the stomach. Annu Rev Physiol, v. 47, p. 199-215, 1985. ISSN 0066-4278. Disponível em: < http://www.ncbi.nlm.nih.gov/pubmed/3922287 >.

BROCKHAUSEN, I. et al. Mucin synthesis. III. UDP-GlcNAc:Gal beta 1-3(GlcNAc beta 1-6)GalNAc-R (GlcNAc to Gal) beta 3-N-acetylglucosaminyltransferase, an enzyme in porcine gastric mucosa involved in the elongation of mucin-type oligosaccharides. Can J Biochem Cell Biol, v. 61, n. 12, p. 1322-1333, Dec 1983. ISSN 0714-7511. Disponível em: < http://www.ncbi.nlm.nih.gov/pubmed/6231087 >. glycosylation shift: prevention by a probiotic treatment. Am J Physiol Gastrointest 
Liver Physiol, v. 307, n. 4, p. G420-429, Aug 2014. ISSN 1522-1547. Disponível em: < http://www.ncbi.nlm.nih.gov/pubmed/24970779 >.

KAWAKUBO, M. et al. Natural antibiotic function of a human gastric mucin against Helicobacter pylori infection. Science, v. 305, n. 5686, p. 1003-1006, Aug 2004. ISSN 1095-9203. Disponível em: < http://www.ncbi.nlm.nih.gov/pubmed/15310903 >.

LAINE, L.; TAKEUCHI, K.; TARNAWSKI, A. Gastric mucosal defense and cytoprotection: bench to bedside. Gastroenterology, v. 135, n. 1, p. 41-60, Jul 2008. ISSN 1528-0012. Disponível em: < http://www.ncbi.nlm.nih.gov/pubmed/18549814 $>$.

BROCKHAUSEN, I. Mucin-type O-glycans in human colon and breast cancer: glycodynamics and functions. EMBO Rep, v. 7, n. 6, p. 599-604, Jun 2006. ISSN 1469-221X. Disponível em: < http://www.ncbi.nlm.nih.gov/pubmed/16741504 >.

HO, S. B. et al. Expression cloning of gastric mucin complementary DNA and localization of mucin gene expression. Gastroenterology, v. 109, n. 3, p. 735-747, Sep 1995. ISSN 0016-5085. Disponível em: < http://www.ncbi.nlm.nih.gov/pubmed/7657101 >.

NORDMAN, H. et al. Gastric MUC5AC and MUC6 are large oligomeric mucins that differ in size, glycosylation and tissue distribution. Biochem J, v. 364, n. Pt 1, p. 191200, May 2002. ISSN 0264-6021. Disponível em: < http://www.ncbi.nlm.nih.gov/pubmed/11988092 >.

QUANTE, M. et al. TFF2 mRNA transcript expression marks a gland progenitor cell of the gastric oxyntic mucosa. Gastroenterology, v. 139, n. 6, p. 2018-2027.e2, Dec 2010. ISSN 1528-0012. Disponível em: < http://www.ncbi.nlm.nih.gov/pubmed/20708616 >.

CAPOCCIA, B. J. et al. The ubiquitin ligase Mindbomb 1 coordinates gastrointestinal secretory cell maturation. J Clin Invest, v. 123, n. 4, p. 1475-1491, Apr 2013. ISSN 1558-8238. Disponível em: < http://www.ncbi.nlm.nih.gov/pubmed/23478405 >.

JOHNSON, C. L. et al. Mist1 is necessary for the establishment of granule organization in serous exocrine cells of the gastrointestinal tract. Mech Dev, v. 121, n. 3, p. 261-272, Mar 2004. ISSN 0925-4773. Disponível em: < http://www.ncbi.nlm.nih.gov/pubmed/15003629 >.

RAMSEY, V. G. et al. The maturation of mucus-secreting gastric epithelial progenitors into digestive-enzyme secreting zymogenic cells requires Mist1. Development, v. 134, n. 1, p. 211-222, Jan 2007. ISSN 0950-1991. Disponível em: < http://www.ncbi.nlm.nih.gov/pubmed/17164426 >. 
TIAN, X. et al. RAB26 and RAB3D are direct transcriptional targets of MIST1 that regulate exocrine granule maturation. Mol Cell Biol, v. 30, n. 5, p. 1269-1284, Mar 2010. ISSN 1098-5549. Disponível em: < http://www.ncbi.nlm.nih.gov/pubmed/20038531 >.

SHAO, J. S.; SCHEPP, W.; ALPERS, D. H. Expression of intrinsic factor and pepsinogen in the rat stomach identifies a subset of parietal cells. Am J Physiol, v. 274, n. 1 Pt 1, p. G62-70, Jan 1998. ISSN 0002-9513. Disponível em: < http://www.ncbi.nlm.nih.gov/pubmed/9458774 >.

FURIHATA, C.; KAWACHI, T.; SUGIMURA, T. Premature induction of pepsinogen in developing rat gastric mucosa by hormones. Biochem Biophys Res Commun, v. 47, n. 4, p. 705-711, May 1972. ISSN 0006-291X. Disponível em: < http://www.ncbi.nlm.nih.gov/pubmed/4337322 >.

KAGEYAMA, T. et al. Molecular cloning of neonate/infant-specific pepsinogens from rat stomach mucosa and their expressional change during development. Biochem Biophys Res Commun, v. 267, n. 3, p. 806-812, Jan 2000. ISSN 0006-291X.

Disponível em: < http://www.ncbi.nlm.nih.gov/pubmed/10673373 >.

ZHU, L. et al. Novel insights of the gastric gland organization revealed by chief cell specific expression of moesin. Am J Physiol Gastrointest Liver Physiol, v. 296, n. 2, p. G185-195, Feb 2009. ISSN 0193-1857. Disponível em: < http://www.ncbi.nlm.nih.gov/pubmed/19074636 >.

KU, N. O. et al. The cytoskeleton of digestive epithelia in health and disease. Am J Physiol, v. 277, n. 6 Pt 1, p. G1108-1137, Dec 1999. ISSN 0002-9513. Disponível em: < http://www.ncbi.nlm.nih.gov/pubmed/10600809 >.

MCCLATCHEY, A. I. ERM proteins. Curr Biol, v. 22, n. 18, p. R784-785, Sep 2012. ISSN 1879-0445. Disponível em: < http://www.ncbi.nlm.nih.gov/pubmed/23017986 $>$.

ZHOU, R. et al. Characterization of protein kinase A-mediated phosphorylation of ezrin in gastric parietal cell activation. J Biol Chem, v. 278, n. 37, p. 35651-35659, Sep 2003. ISSN 0021-9258. Disponível em: < http://www.ncbi.nlm.nih.gov/pubmed/12840026 >. support in developing countries. Geneva: WHO, 2003. viII, 29 p. ISBN 9241591218. 
SCHWARZ, E. B. et al. Duration of lactation and risk factors for maternal cardiovascular disease. Obstet Gynecol, v. 113, n. 5, p. 974-982, May 2009. ISSN 0029-7844. Disponível em: < http://www.ncbi.nlm.nih.gov/pubmed/19384111 >.

WALKER, A. Breast milk as the gold standard for protective nutrients. J Pediatr, v. 156, n. 2 Suppl, p. S3-7, Feb 2010. ISSN 1097-6833. Disponível em: < http://www.ncbi.nlm.nih.gov/pubmed/20105662 >.

HENNING, S. J. Postnatal development: coordination of feeding, digestion, and metabolism. Am J Physiol, v. 241, n. 3, p. G199-214, Sep 1981. ISSN 0002-9513. Disponível em: < http://www.ncbi.nlm.nih.gov/pubmed/7025659 >.

KOLDOVSKÝ, O. Response of the gastrointestinal tract to premature weaning in experimental animals. Pediatrics, v. 75, n. 1 Pt 2, p. 199-206, Jan 1985. ISSN 00314005. Disponível em: < http://www.ncbi.nlm.nih.gov/pubmed/3966052 >.

KOLDOVSKÝ, O. et al. Milk-borne hormones: possible tools of communication between mother and suckling. Physiol Res, v. 44, n. 6, p. 349-351, 1995. ISSN 08628408. Disponível em: < http://www.ncbi.nlm.nih.gov/pubmed/8798268 >.

GAMA, P.; ALVARES, E. P. LHRH and somatostatin effects on the cell proliferation of the gastric epithelium of suckling and weaning rats. Regul Pept, v. 63, n. 2-3, p. 73-78, Jul 1996. ISSN 0167-0115. Disponível em: < http://www.ncbi.nlm.nih.gov/pubmed/8837213 >.

ROGIER, E. W. et al. Secretory antibodies in breast milk promote long-term intestinal homeostasis by regulating the gut microbiota and host gene expression. Proc Natl Acad Sci U S A, v. 111, n. 8, p. 3074-3079, Feb 2014. ISSN 1091-6490. Disponível em: < http://www.ncbi.nlm.nih.gov/pubmed/24569806 >.

KOLDOVSKÝ, O. Search for role of milk-borne biologically active peptides for the suckling. J Nutr, v. 119, n. 11, p. 1543-1551, Nov 1989. ISSN 0022-3166. Disponível em: < http://www.ncbi.nlm.nih.gov/pubmed/2689607 >.

DE ANDRADE SÁ, E. R. et al. Ontogenic expression of TGFbeta 1, 2, and 3 and its receptors in the rat gastric mucosa. Dev Dyn, v. 227, n. 3, p. 450-457, Jul 2003. ISSN 1058-8388. Disponível em: < http://www.ncbi.nlm.nih.gov/pubmed/12815632 >.

LIN, C. H. et al. Early weaning induces jejunal ornithine decarboxylase and cell proliferation in neonatal rats. J Nutr, v. 128, n. 10, p. 1636-1642, Oct 1998. ISSN 0022-3166. Disponível em: < http://www.ncbi.nlm.nih.gov/pubmed/9772129 >. 
BOYLE, J. T.; KOLDOVSKÝ, O. Critical role of adrenal glands in precocious increase in jejunal sucrase activity following premature weaning in rats: negligible effect of food intake. J Nutr, v. 110, n. 1, p. 169-177, Jan 1980. ISSN 0022-3166. Disponível em: 〈 http://www.ncbi.nlm.nih.gov/pubmed/6766500 >. cell proliferation in the gastric epithelium of developing rats. J Nutr, v. 130, n. 10, p. 2594-2598, Oct 2000. ISSN 0022-3166. Disponível em: < http://www.ncbi.nlm.nih.gov/pubmed/11015495 >. cells in rat gastric mucosa: possible role of TGFalpha/EGFR. Differentiation, v. 79, n. 1, p. 48-56, Jan 2010. ISSN 1432-0436. Disponível em: < http://www.ncbi.nlm.nih.gov/pubmed/19783352 >.

. EGFR is involved in control of gastric cell proliferation through activation of MAPK and Src signalling pathways in early-weaned rats. Cell Prolif, v. 44, n. 2, p. 174-182, Apr 2011. ISSN 1365-2184. Disponível em: < http://www.ncbi.nlm.nih.gov/pubmed/21401759 >.

OGIAS, D. et al. Opposite effects of fasting on TGF-beta3 and TbetaRI distribution in the gastric mucosa of suckling and early weanling rats. Nutrition, v. 26, n. 2, p. 224-9, Feb 2010. ISSN 1873-1244. Disponível em: < http://www.ncbi.nlm.nih.gov/pubmed/19524404 >.

BITTAR, N. M. et al. Ghrelin and GHS-R in the rat gastric mucosa: Are they involved in regulation of growth during early weaning? Nutrition, v. 32, n. 1, p. 1017, Jan 2016. ISSN 1873-1244. Disponível em: < http://www.ncbi.nlm.nih.gov/pubmed/26520918 >. effects on gastric cell proliferation. Nutrition, v. 30, n. 3, p. 343-349, Mar 2014. ISSN 1873-1244. Disponível em: < http://www.ncbi.nlm.nih.gov/pubmed/24484684 >.

ACKERMAN, S. H.; HOFER, M. A.; WEINER, H. Predisposition to gastric erosions in the rat: behavioral and nutritional effects of early maternal separation. Gastroenterology, v. 75, n. 4, p. 649-654, Oct 1978. ISSN 0016-5085. Disponível em: < http://www.ncbi.nlm.nih.gov/pubmed/710833 >. stress ulcer formation. Physiol Behav, v. 34, n. 6, p. 907-909, Jun 1985. ISSN 00319384. Disponível em: < http://www.ncbi.nlm.nih.gov/pubmed/4059380 >. 
LACKEYRAM, D. et al. Early weaning reduces small intestinal alkaline phosphatase expression in pigs. J Nutr, v. 140, n. 3, p. 461-468, Mar 2010. ISSN 1541-6100. Disponível em: < http://www.ncbi.nlm.nih.gov/pubmed/20089775 >.

SMITH, F. et al. Early weaning stress impairs development of mucosal barrier function in the porcine intestine. Am J Physiol Gastrointest Liver Physiol, v. 298, n. 3, p. G352-363, Mar 2010. ISSN 1522-1547. Disponível em: < http://www.ncbi.nlm.nih.gov/pubmed/19926814 >.

ORGEUR, P. et al. Behavioural, growth and immune consequences of early weaning in one-week-old large-white piglets. Reprod Nutr Dev, v. 41, n. 4, p. 321-332, 2001 Jul-Aug 2001. ISSN 0926-5287. Disponível em: < http://www.ncbi.nlm.nih.gov/pubmed/11789889 >.

KIKUSUI, T.; MORI, Y. Behavioural and neurochemical consequences of early weaning in rodents. J Neuroendocrinol, v. 21, n. 4, p. 427-431, Mar 2009. ISSN 1365-2826. Disponível em: < http://www.ncbi.nlm.nih.gov/pubmed/19207810 >.

FATURI, C. B. et al. Disruptions of the mother-infant relationship and stress-related behaviours: altered corticosterone secretion does not explain everything. Neurosci Biobehav Rev, v. 34, n. 6, p. 821-834, May 2010. ISSN 1873-7528. Disponível em: < http://www.ncbi.nlm.nih.gov/pubmed/19751762 >.

SCHMIDT, M. et al. Maternal regulation of the hypothalamic-pituitary-adrenal axis in the 20-day-old rat: consequences of laboratory weaning. J Neuroendocrinol, v. 14, n. 6, p. 450-7, Jun 2002. ISSN 0953-8194. Disponível em: < http://www.ncbi.nlm.nih.gov/pubmed/12047720 >.

OGIAS, D. et al. Can gastric cell differentiation be reprogrammed by early life stress? ASCB annual meeting. San Diego, California. v. 26, p. 735, 2015.

BOCKMÜHL, Y. et al. Methylation at the $\mathrm{CpG}$ island shore region upregulates $\mathrm{Nr} 3 \mathrm{c} 1$ promoter activity after early-life stress. Epigenetics, v. 10, n. 3, p. 247-257, 2015. ISSN 1559-2308. Disponível em: < http://www.ncbi.nlm.nih.gov/pubmed/25793778 >.

BARKER, D. J. Developmental origins of adult health and disease. J Epidemiol Community Health, v. 58, n. 2, p. 114-115, Feb 2004. ISSN 0143-005X. Disponível em: < http://www.ncbi.nlm.nih.gov/pubmed/14729887 >. Health, v. 126, n. 3, p. 185-189, Mar 2012. ISSN 1476-5616. Disponível em: < http://www.ncbi.nlm.nih.gov/pubmed/22325676 >. 
LANGLEY-EVANS, S. C.; MCMULLEN, S. Developmental origins of adult disease. Med Princ Pract, v. 19, n. 2, p. 87-98, 2010. ISSN 1423-0151. Disponível em: < http://www.ncbi.nlm.nih.gov/pubmed/20134170 >.

BATESON, P. Developmental plasticity and evolutionary biology. J Nutr, v. 137, n. 4, p. 1060-1062, Apr 2007. ISSN 0022-3166. Disponível em: < http://www.ncbi.nlm.nih.gov/pubmed/17374677 >. consequences for later disease: a life history and evolutionary perspective. Am J Hum Biol, v. 19, n. 1, p. 1-19, 2007 Jan-Feb 2007. ISSN 1042-0533. Disponível em: < http://www.ncbi.nlm.nih.gov/pubmed/17160980 >.

FLESHNER, M. et al. A long-term increase in basal levels of corticosterone and a decrease in corticosteroid-binding globulin after acute stressor exposure.

Endocrinology, v. 136, n. 12, p. 5336-5342, Dec 1995. ISSN 0013-7227. Disponível em: < http://www.ncbi.nlm.nih.gov/pubmed/7588279 >.

YUDT, M. R.; CIDLOWSKI, J. A. The glucocorticoid receptor: coding a diversity of proteins and responses through a single gene. Mol Endocrinol, v. 16, n. 8, p. 17191726, Aug 2002. ISSN 0888-8809. Disponível em: < http://www.ncbi.nlm.nih.gov/pubmed/12145329 >.

AXELROD, J.; REISINE, T. D. Stress hormones: their interaction and regulation. Science, v. 224, n. 4648, p. 452-459, May 1984. ISSN 0036-8075. Disponível em: < http://www.ncbi.nlm.nih.gov/pubmed/6143403 >.

SORRELLS, S. F. et al. The stressed CNS: when glucocorticoids aggravate inflammation. Neuron, v. 64, n. 1, p. 33-39, Oct 2009. ISSN 1097-4199. Disponível em: < http://www.ncbi.nlm.nih.gov/pubmed/19840546 >.

HENNING, S. J. Plasma concentrations of total and free corticosterone during development in the rat. Am J Physiol, v. 235, n. 5, p. E451-456, Nov 1978. ISSN 0002-9513. Disponível em: < http://www.ncbi.nlm.nih.gov/pubmed/103438 >.

TSENG, C. C.; JOHNSON, L. R. Does corticosterone affect gastric mucosal cell growth during development? Am J Physiol, v. 250, n. 5 Pt 1, p. G633-638, May 1986. ISSN 0002-9513. Disponível em: < http://www.ncbi.nlm.nih.gov/pubmed/2422954 >.

GAMA, P.; ALVARES, E. P. Corticosterone treatment inhibits cell proliferation in the gastric epithelium of suckling rats. J Gastroenterol, v. 33, n. 1, p. 32-38, Feb 1998. ISSN 0944-1174. Disponível em: < http://www.ncbi.nlm.nih.gov/pubmed/9497219 >. 
OGIAS, D. et al. Fasting differentially regulates plasma corticosterone-binding globulin, glucocorticoid receptor, and cell cycle in the gastric mucosa of pups and adult rats. Am J Physiol Gastrointest Liver Physiol, v. 298, n. 1, p. G117-125, Jan 2010. ISSN 1522-1547. Disponível em: < http://www.ncbi.nlm.nih.gov/pubmed/19833863 >.

Can gastric cell differentiation be reprogrammed by early life stress? ASCB annual meeting. San Diego, California. 26: 735 p. 2015.

BAMBERGER, C. M. et al. Inhibition of mineralocorticoid and glucocorticoid receptor function by the heat shock protein 90-binding agent geldanamycin. Mol Cell Endocrinol, v. 131, n. 2, p. 233-240, Aug 1997. ISSN 0303-7207. Disponível em: < http://www.ncbi.nlm.nih.gov/pubmed/9296382 >.

DE BOSSCHER, K.; VANDEN BERGHE, W.; HAEGEMAN, G. The interplay between the glucocorticoid receptor and nuclear factor-kappaB or activator protein-1: molecular mechanisms for gene repression. Endocr Rev, v. 24, n. 4, p. 488-522, Aug 2003. ISSN 0163-769X. Disponível em: < http://www.ncbi.nlm.nih.gov/pubmed/12920152 >.

KATO, K. et al. Coexpression of mineralocorticoid receptors and 11betahydroxysteroid dehydrogenase 2 in human gastric mucosa. J Clin Endocrinol Metab, v. 84, n. 7, p. 2568-2573, Jul 1999. ISSN 0021-972X. Disponível em: < http://www.ncbi.nlm.nih.gov/pubmed/10404838 >.

FULLER, P. J.; VERITY, K. Mineralocorticoid receptor gene expression in the gastrointestinal tract: distribution and ontogeny. J Steroid Biochem, v. 36, n. 4, p. 263-267, Jul 1990. ISSN 0022-4731. Disponível em: < http://www.ncbi.nlm.nih.gov/pubmed/2168006 >.

REICHARDT, S. D. et al. Glucocorticoids enhance intestinal glucose uptake via the dimerized glucocorticoid receptor in enterocytes. Endocrinology, v. 153, n. 4, p. 1783-1794, Apr 2012. ISSN 1945-7170. Disponível em: < http://www.ncbi.nlm.nih.gov/pubmed/22294744 >.

FIGUEIREDO, P. M. Papel da interação entre padrão alimentar, corticosterona e fatores de crescimento na regulação da proliferação celular no epitélio gástrico de ratos em desenvolvimento pós-natal. 2010. 100 f . (Mestrado em Ciências). Instituto de Ciências Biomédicas, Universidade de São Paulo, São Paulo, 2015. 
MAHAJAN, D. K.; LONDON, S. N. Mifepristone (RU486): a review. Fertil Steril, v. 68, n. 6, p. 967-976, Dec 1997. ISSN 0015-0282. Disponível em: < http://www.ncbi.nlm.nih.gov/pubmed/9418681 >. current knowledge and future prospects. Arch Fam Med, v. 7, n. 3, p. 219-222, 1998 May-Jun 1998. ISSN 1063-3987. Disponível em: < http://www.ncbi.nlm.nih.gov/pubmed/9596454 >. glucocorticoid and progesterone receptors. Endocrinology, v. 133, n. 2, p. 728-740, Aug 1993. ISSN 0013-7227. Disponível em: < http://www.ncbi.nlm.nih.gov/pubmed/8344212 >. mechanisms of action and clinical uses. Annu Rev Med, v. 48, p. 129-156, 1997. ISSN 0066-4219. Disponível em: < http://www.ncbi.nlm.nih.gov/pubmed/9046951 >.

PECCI, A. et al. New lead compounds in the search for pure antiglucocorticoids and the dissociation of antiglucocorticoid effects. J Steroid Biochem Mol Biol, v. 113, n. 3-5, p. 155-162, Feb 2009. ISSN 1879-1220. Disponível em: < http://www.ncbi.nlm.nih.gov/pubmed/19167494 >.

FILARETOVA, L.; BAGAEVA, T.; MAKARA, G. B. Aggravation of nonsteroidal antiinflammatory drug gastropathy by glucocorticoid deficiency or blockade of glucocorticoid receptors in rats. Life Sci, v. 71, n. 21, p. 2457-2468, Oct 2002. ISSN 0024-3205. Disponível em: < http://www.ncbi.nlm.nih.gov/pubmed/12270751 >. glucocorticoid-induced protein kinase isoforms. Sci STKE, v. 2001, n. 108, p. re17, Nov 2001. ISSN 1525-8882. Disponível em: < http://www.ncbi.nlm.nih.gov/pubmed/11707620 >.

SANDU, C. et al. Role of the serum and glucocorticoid inducible kinase SGK1 in glucocorticoid stimulation of gastric acid secretion. Pflugers Arch, v. 455, n. 3, p. 493-503, Dec 2007. ISSN 0031-6768. Disponível em: < http://www.ncbi.nlm.nih.gov/pubmed/17618452 >.

WEBSTER, M. K. et al. Characterization of sgk, a novel member of the serine/threonine protein kinase gene family which is transcriptionally induced by glucocorticoids and serum. Mol Cell Biol, v. 13, n. 4, p. 2031-2040, Apr 1993. ISSN 0270-7306. Disponível em: < http://www.ncbi.nlm.nih.gov/pubmed/8455596 >. 
WANG, D. et al. Acute activation of NHE3 by dexamethasone correlates with activation of SGK1 and requires a functional glucocorticoid receptor. Am J Physiol Cell Physiol, v. 292, n. 1, p. C396-404, Jan 2007. ISSN 0363-6143. Disponível em: < http://www.ncbi.nlm.nih.gov/pubmed/16971495 >.

YAYLAOGLU, M. B. et al. Diverse patterns of cell-specific gene expression in response to glucocorticoid in the developing small intestine. Am J Physiol Gastrointest Liver Physiol, v. 291, n. 6, p. G1041-1050, Dec 2006. ISSN 0193-1857. Disponível em: < http://www.ncbi.nlm.nih.gov/pubmed/16825705 >.

KUMEGAWA, M. et al. Precocious induction of pepsinogen in the stomach of suckling mice by hormones. Biochim Biophys Acta, v. 543, n. 2, p. 243-250, Oct 1978. ISSN 0006-3002. Disponível em: < http://www.ncbi.nlm.nih.gov/pubmed/728462 >.

TSUKADA, S. et al. Induction of precocious pepsinogen synthesis by glucocorticoids in fetal rat gastric epithelium in organ culture: importance of mesenchyme for epithelial differentiation. Differentiation, v. 62, n. 5, p. 239-247, Mar 1998. ISSN 0301-4681. Disponível em: < http://www.ncbi.nlm.nih.gov/pubmed/9566309 >.

MARTÍNEZ-ANTÓN, A. et al. Corticosteroid therapy increases membrane-tethered while decreases secreted mucin expression in nasal polyps. Allergy, v. 63, n. 10, p. 1368-1376, Oct 2008. ISSN 1398-9995. Disponível em: < http://www.ncbi.nlm.nih.gov/pubmed/18547287 >.

WOO, H. J. et al. Expression of membrane-bound mucins in human nasal mucosa: different patterns for MUC4 and MUC16. Arch Otolaryngol Head Neck Surg, v. 136, n. 6, p. 603-609, Jun 2010. ISSN 1538-361X. Disponível em: < http://www.ncbi.nlm.nih.gov/pubmed/20566912 >. mRNA expression in the rat stomach. Biol Pharm Bull, v. 26, n. 7, p. 927-930, Jul 2003. ISSN 0918-6158. Disponível em: < http://www.ncbi.nlm.nih.gov/pubmed/12843612 >.

SEO, K. Y. et al. Regulation of membrane-associated mucins in the human corneal epithelial cells by dexamethasone. Cornea, v. 26, n. 6, p. 709-714, Jul 2007. ISSN 0277-3740. Disponível em: < http://www.ncbi.nlm.nih.gov/pubmed/17592322 >. galactosylation and fucosylation processes in the rat small intestine. J Steroid Biochem Mol Biol, v. 84, n. 4, p. 411-422, Mar 2003. ISSN 0960-0760. Disponível em: < http://www.ncbi.nlm.nih.gov/pubmed/12732286 >. 
ALVARES, E. P.; GAMA, P. Fasting enhances cell proliferation of gastric epithelium during the suckling period in rats. Braz J Med Biol Res, v. 26, n. 8, p. 869-873, Aug 1993. ISSN 0100-879X. Disponível em: < http://www.ncbi.nlm.nih.gov/pubmed/8298523 >.

DE ANDRADE SÁ, E. R. et al. In vivo effects of TGFbeta1 on the growth of gastric epithelium in suckling rats. Regul Pept, v. 146, n. 1-3, p. 293-302, Feb 2008. ISSN 0167-0115. Disponível em: < http://www.ncbi.nlm.nih.gov/pubmed/18068234 >. comparative C(T) method. Nat Protoc, v. 3, n. 6, p. 1101-1108, 2008. ISSN 17502799. Disponível em: < http://www.ncbi.nlm.nih.gov/pubmed/18546601 >.

Digestion, v. 63, n. 4, p. 214-219, 2001. ISSN 0012-2823. Disponível em: < http://www.ncbi.nlm.nih.gov/pubmed/11435720 >.

NORDMAN, H. et al. Mucus glycoproteins from pig gastric mucosa: identification ofdifferent mucin populations from the surface epithelium. Biochem J, v. 326 ( Pt 3), p. 903-910, Sep 1997. ISSN 0264-6021. Disponível em: < http://www.ncbi.nlm.nih.gov/pubmed/9307044 >.

REIS, C. A. et al. Immunohistochemical study of the expression of MUC6 mucin and co-expression of other secreted mucins (MUC5AC and MUC2) in human gastric carcinomas. J Histochem Cytochem, v. 48, n. 3, p. 377-388, Mar 2000. ISSN 00221554. Disponível em: < http://www.ncbi.nlm.nih.gov/pubmed/10681391 >.

BROCKHAUSEN, I. et al. The separation by liquid chromatography (under elevated pressure) of phenyl, benzyl, and O-nitrophenyl glycosides of oligosaccharides. Analysis of substrates and products for four N-acetyl-D-glucosaminyl-transferases involved in mucin synthesis. Carbohydr Res, v. 120, p. 3-16, Aug 1983. ISSN 00086215. Disponível em: < http://www.ncbi.nlm.nih.gov/pubmed/6226356 >. Microbiol, v. 9, n. 4, p. 265-78, Apr 2011. ISSN 1740-1534. Disponível em: < http://www.ncbi.nlm.nih.gov/pubmed/21407243 >.

NANTHAKUMAR, N. N.; MENG, D.; NEWBURG, D. S. Glucocorticoids and microbiota regulate ontogeny of intestinal fucosyltransferase 2 requisite for gut homeostasis. Glycobiology, v. 23, n. 10, p. 1131-1141, Oct 2013. ISSN 1460-2423. Disponível em: < http://www.ncbi.nlm.nih.gov/pubmed/23887940 >. apomucin and Lewis antigen expression in normal and malignant gastric epithelium. 
Gut, v. 47, n. 3, p. 349-356, Sep 2000. ISSN 0017-5749. Disponível em: < http://www.ncbi.nlm.nih.gov/pubmed/10940270 >.

GE, Y. B. et al. Immunocytochemistry and in situ hybridization studies of pepsinogen C-producing cells in developing rat fundic glands. Cell Tissue Res, v. 293, n. 1, p. 121-131, Jul 1998. ISSN 0302-766X. Disponível em: < http://www.ncbi.nlm.nih.gov/pubmed/9634604 >.

SMITH, S. S.; OJEDA, S. R. Maternal modulation of infantile ovarian development and available ovarian luteinizing hormone-releasing hormone (LHRH) receptors via milk LHRH. Endocrinology, v. 115, n. 5, p. 1973-1983, Nov 1984. ISSN 0013-7227. Disponível em: < http://www.ncbi.nlm.nih.gov/pubmed/6092043 >.

BABYGIRIJA, R. et al. Social interaction attenuates stress responses following chronic stress in maternally separated rats. Brain Res, v. 1469, p. 54-62, Aug 2012. ISSN 1872-6240. Disponível em: < http://www.ncbi.nlm.nih.gov/pubmed/22750582 $>$.

MANIAM, J. et al. Sugar Consumption Produces Effects Similar to Early Life Stress Exposure on Hippocampal Markers of Neurogenesis and Stress Response. Front Mol Neurosci, v. 8, p. 86, 2015. ISSN 1662-5099. Disponível em: < http://www.ncbi.nlm.nih.gov/pubmed/26834554 >. production, growth and certain parameters of the digestive tract in rabbits. Animal, v. 6, n. 6, p. 894-901, Jun 2012. ISSN 1751-732X. Disponível em: < http://www.ncbi.nlm.nih.gov/pubmed/22558959 >.

OSAKI, L. H.; GAMA, P. MAPK signaling pathway regulates p27 phosphorylation at threonin 187 as part of the mechanism triggered by early-weaning to induce cell proliferation in rat gastric mucosa. PLoS One, v. 8, n. 6, p. e66651, 2013. ISSN 1932-6203. Disponível em: < http://www.ncbi.nlm.nih.gov/pubmed/23762493 >. Dyslipidemia Act via a Unique Association with an Agonist Binding Site. J Med Chem, v. 58, n. 16, p. 6607-6618, Aug 2015. ISSN 1520-4804. Disponível em: < http://www.ncbi.nlm.nih.gov/pubmed/26218343 >. androgen-targeted therapy in prostate cancer. Horm Cancer, v. 5, n. 2, p. 72-89, Apr 2014. ISSN 1868-8500. Disponível em: < http://www.ncbi.nlm.nih.gov/pubmed/24615402 >. 

mediate responses to Staphylococcus aureus in epithelial cells. Nat Med, v. 8, n. 1, p. 41-46, Jan 2002. ISSN 1078-8956. Disponível em: < http://www.ncbi.nlm.nih.gov/pubmed/11786905 >. transforming growth factor- $\alpha$ in human respiratory cells. Allergol Int, v. 61, n. 3, p. 451-459, Sep 2012. ISSN 1440-1592. Disponível em: < http://www.ncbi.nlm.nih.gov/pubmed/22824974 >.

TAKEYAMA, K. et al. Epidermal growth factor system regulates mucin production in airways. Proc Natl Acad Sci U S A, v. 96, n. 6, p. 3081-3086, Mar 1999. ISSN 0027-8424. Disponível em: < http://www.ncbi.nlm.nih.gov/pubmed/10077640 >. growth factor receptor: role of neutrophils. J Immunol, v. 164, n. 3, p. 1546-1552, Feb 2000. ISSN 0022-1767. Disponível em: < http://www.ncbi.nlm.nih.gov/pubmed/10640773 >. glycoproteins in health and disease. Physiol Rev, v. 86, n. 1, p. 245-278, Jan 2006. ISSN 0031-9333. Disponível em: < http://www.ncbi.nlm.nih.gov/pubmed/16371599 $>$. Pediatr Res, v. 22, n. 3, p. 250-256, Sep 1987. ISSN 0031-3998. Disponível em: < http://www.ncbi.nlm.nih.gov/pubmed/2443895 >.

BARROW, P. A.; FULLER, R.; NEWPORT, M. J. Changes in the microflora and physiology of the anterior intestinal tract of pigs weaned at 2 days, with special reference to the pathogenesis of diarrhea. Infect Immun, v. 18, n. 3, p. 586-595, Dec 1977. ISSN 0019-9567. Disponível em: < http://www.ncbi.nlm.nih.gov/pubmed/22488 >.

XU, J. et al. Regulation of an antioxidant blend on intestinal redox status and major microbiota in early weaned piglets. Nutrition, v. 30, n. 5, p. 584-589, May 2014. ISSN 1873-1244. Disponível em: < http://www.ncbi.nlm.nih.gov/pubmed/24698350 $>$. 6618. Disponível em: < http://www.ncbi.nlm.nih.gov/pubmed/24092857 >. 
TSENG, M. et al. Shiga toxin-producing E. coli (STEC) in swine: prevalence over the finishing period and characteristics of the STEC isolates. Epidemiol Infect, v. 143, n. 3, p. 505-514, Feb 2015. ISSN 1469-4409. Disponível em: < http://www.ncbi.nlm.nih.gov/pubmed/24810787 >.

BAO, W. B. et al. Microarray analysis of differential gene expression in sensitive and resistant pig to Escherichia coli F18. Anim Genet, v. 43, n. 5, p. 525-534, Oct 2012. ISSN 1365-2052. Disponível em: < http://www.ncbi.nlm.nih.gov/pubmed/22497274 $>$.

MCLAMB, B. L. et al. Early weaning stress in pigs impairs innate mucosal immune responses to enterotoxigenic E. coli challenge and exacerbates intestinal injury and clinical disease. PLoS One, v. 8, n. 4, p. e59838, 2013. ISSN 1932-6203. Disponível em: < http://www.ncbi.nlm.nih.gov/pubmed/23637741 >.

TSUKADA, S. et al. Glucocorticoids inhibit the proliferation of mucosal cells and enhance the expression of a gene for pepsinogen and other markers of differentiation in the stomach mucosa of the adult rat. Biochem Biophys Res Commun, v. 202, n. 1, p. 1-9, Jul 1994. ISSN 0006-291X. Disponível em: < http://www.ncbi.nlm.nih.gov/pubmed/8037699 >.

JORDAN, N. et al. A novel method for the visualization of the in situ mucus layer in rat and man. Clin Sci (Lond), v. 95, n. 1, p. 97-106, Jul 1998. ISSN 0143-5221. Disponível em: < http://www.ncbi.nlm.nih.gov/pubmed/9662491 >.

FALK, P.; ROTH, K. A.; GORDON, J. I. Lectins are sensitive tools for defining the differentiation programs of mouse gut epithelial cell lineages. Am J Physiol, v. 266, n. 6 Pt 1, p. G987-1003, Jun 1994. ISSN 0002-9513. Disponível em: < http://www.ncbi.nlm.nih.gov/pubmed/8023947 >.

DAS, I. et al. Glucocorticoids alleviate intestinal ER stress by enhancing protein folding and degradation of misfolded proteins. J Exp Med, v. 210, n. 6, p. 1201-1216, Jun 2013. ISSN 1540-9538. Disponível em: < http://www.ncbi.nlm.nih.gov/pubmed/23650437 >.

GIBSON, J. A. et al. MUC expression in hyperplastic and serrated colonic polyps: lack of specificity of MUC6. Am J Surg Pathol, v. 35, n. 5, p. 742-749, May 2011. ISSN 1532-0979. Disponível em: < http://www.ncbi.nlm.nih.gov/pubmed/21490447 $>$.

HUH, W. J. et al. XBP1 controls maturation of gastric zymogenic cells by induction of MIST1 and expansion of the rough endoplasmic reticulum. Gastroenterology, v. 139, n. 6, p. 2038-2049, Dec 2010. ISSN 1528-0012. Disponível em: < http://www.ncbi.nlm.nih.gov/pubmed/20816838 >. 

v. 18, n. 1, p. 7-9, Jan 2016. ISSN 1875-9777. Disponível em: < http://www.ncbi.nlm.nih.gov/pubmed/26748749 >. 